\title{
Pleistocene Canidae (Mammalia, Carnivora) from the Paleolithic Kudaro caves in the Caucasus
}

\author{
Gennady F. Baryshnikov
}

\begin{abstract}
The analysis of bone assemblages from the Kudaro Paleolithic sites in Southern Ossetia provides a basis for identification of seven species of canids. The Middle Pleistocene fauna contains Canis arnensis kudarensis subsp. nov., C. mosbachensis, C. lunellensis, Vulpes praeglacialis, and V. vulpes, while the Late Pleistocene fauna contains Canis lupus, Cuon alpinus caucasicus, and Vulpes vulpes. Fossil remains of Canis arnensis, C. mosbachensis, and C. lunellensis represent the latest finds for Eurasia.
\end{abstract}

KEY WORDS: Canidae, Pleistocene, Paleolithic cave sites, Caucasus, taxonomy.

Gennady F. Baryshnikov [G_Baryshnikov@mail.ru], Zoological Institute, Russian Academy of Sciences, Universitetskaya nab. 1, Saint Petersburg 199034, Russia.

\section{Плейстоценовые псовые (Mammalia, Carnivora, Canidae) из Кударских пещерных палеолитических стоянок на Кавказе}

\section{Г.Ф. Барышников}

\begin{abstract}
РЕЗЮМЕ. Анализ костного скопления в Кударских палеолитических стоянках в Южной Осетии позволил выявить семь видов псовых. Среднеплейстоценовая фауна включает Canis arnensis kudarensis subsp. nov., C. mosbachensis, C. lunellensis, Vulpes praeglacialis and V. vulpes, в то время как фауна позднего плейстоцена содержит Canis lupus, Cuon alpinus caucasicus and Vulpes vulpes. Находки Canis arnensis, C. mosbachensis, and C. lunellensis являются одними из позднейших в Евразии.
\end{abstract}

КЛЮЧЕВЫЕ СЛОВА: Canidae, плейстоцен, палеолитические пещерные стоянки, Кавказ, систематика.

\section{Introduction}

The canid fauna of Northern Eurasia comprises six recent species: Canis aureus L., 1758, C. lupus L., 1758, Cuon alpinus (Pallas, 1811), Vulpes lagopus (L., 1758), V. corsac (L., 1768) and $V$. vulpes (L., 1758). Four species (Canis aureus, C. lupus, Vulpes corsak and $V$. vulpes) are known to occur in the Caucasus, where they are widely distributed, with the exception of $V$. corsac, which is confined to the arid regions of Northern Caucasus. One more species, Nyctereutes procyonoides (Gray, 1834), has been recently introduced to Caucasus from the Eastern Asia.

In the Late Pleistocene of Western Europe, the canid fauna comprised five species (Canis lupus, Cuon alpinus, Vulpes lagopus, V. corsak and V. vulpes) (Sommer \& Benecke, 2005). Canis aureus appeared there only in Holocene (Greek Neolithic). The data on the Pleistocene fauna of north-latitude Eastern Europe and Northern Asia contain Canis lupus and Vulpes lagopus. It was supplemented by $V$. vulpes in more southern regions, by $V$. corsac in steppe, and by Cuon alpinus in mountains of Siberia.

Thus, no considerable difference is revealed between canid taxonomic diversity of the Late Pleis- tocene and that of the recent epoch. Variation is mainly determined by changes in the range of distribution of several species, which is especially marked for Cuon alpinus and Vulpes lagopus.

Meanwhile the canid fauna is found to be noticeably more peculiar in the late Early and Middle Pleistocene of Europe. The genus Canis includes C. etruscus Forsyth Major, 1877, C. arnensis Del Campana, 1913, C. mosbachensis Soergel, 1925, C. senezensis Martin, 1973, and C. accitanus Garrido et Arribas, 2008 (Thenius, 1954; Torre, 1967; Kurtén, 1968; Bonifay, 1971; Bishop, 1982; Koufos, 1987; Argant, 1991; Rock \& Torre, 1996; Sotnikova, 2001; Garrido \& Arribas, 2008; Baryshnikov \& Tsoukala, 2010). Recently, it was proposed to classify them into two size-groups (species): small C. arnensis (including accitanus) and medium $C$. etruscus (including mosbachensis) (Brugal \& BoudadiMaligne, 2011). In addition, there were described from China C. chihliensis Zdansky, 1924 and C. variabilis Pei, 1934; their relationships with the European species are not clear (see Tedford et al., 2009). Presumably, these Chinese species may be synonymized with the European ones. For example, $C$. mosbachensis and $C$. variabilis represent chronological contemporaries and are similar in morphology. There are also canid repre- 
sentatives belonging to other genera, such as Lycaon lycaonoides (Kretzoi, 1938), Cuon priscus Thenius, 1954, Vulpes alopecoides Forsyth Major, 1877, V.praeglacialis Kormos, 1932, V. praecorsak Kormos, 1932, 1934 and V. vulpes (Kurtén, 1968; Bonifay, 1971; Martínez-Navarro \& Rook, 2003).

The Pleistocene history of Caucasian canids is poorly investigated and may be elucidated in a course of examination of the fossil material from the Kudaro cave sites in Caucasus. The Lower Paleolithic sites in the caves of Kudaro 1 and Kudaro 3 in the southern Caucasus were discovered in 1955 by Prof. V. Lioubine (St. Petersburg), who was the leader of long-term multidisciplinary studies there. Extensive fossil material has been collected owing to careful inspection and selective screen-washing of the cave sediments during archeological excavations.

Vereshchagin (1957) identified from Kudaro 1 Cave Canis cf. lupus and Vulpes cf. vulpes, which were then supplemented by Cuon sp. (Vereshchagin, 1959). Later the large wolf (Canis lupus) was identified in the Mousterian layers and small wolf (C. cf. lupus) was found in the Acheulean layers (Vereshchagin \& Baryshnikov, 1980). Baryshnikov (1978, 1986, 1995, 1996) described the new fossil subspecies Cuon alpinus caucasicus and provided a detailed characteristics of Canis remains, identifying three species within both Kudaro caves: $C$. ex gr. latrans, $C$. cf. etruscus and $C$. lupus.

This communication deals with the new analysis of the Kudaro canid collection, including the first detailed review of the fossil foxes. This study continues a series of publications dealing with the Pleistocene fauna of Carnivora from Kudaro Paleolithic cave sites (Baryshnikov, 1998, 2010a, b, 2011a, b).

\section{Localities and material}

The Kudaro caves are situated in the central part of southern slope of the Greater Caucasus $\left(42^{\circ} 31^{\prime \prime} \mathrm{N}\right.$, $\left.43^{\circ} 38^{\prime \prime} \mathrm{E}\right)$. The caves are placed virtually one above the other on the left bank of Djedjori River (Rioni River bassin) near Kvaisa City (Southern Ossetia).

Kudaro 1 Cave is located at $1600 \mathrm{~m}$ above sea. The thickness of sediments varies in the different parts of the cave from 1.5 to $4.5 \mathrm{~m}$. The deposits contain many limestone detritus markedly corroded in lower stratigraphical levels. Layers $5 \mathrm{a}-5 \mathrm{c}$, which is composed of yellowish fuscous loam, yielded a Late Acheulean industry. The sediment of layers 3-4, representing grayish loam, yielded Mousterian artifacts.

The cave deposits in their basal portion have been dated by radiothermoluminescence method to $360,000 \pm$ 90,000 years before present (RTL-379) for layer 5c (Lioubine 1998). Fossil remains from this layer belong to thermophilic mammals (Macaca sp., Ursus thibetanus G. Cuvier, Hystrix indica Kerr, and H. brachyura vinogradovi Argiropulo; Baryshnikov, 1998), which corresponds to a warm period in the Middle Pleistocene. It may be compared with the Holstein Interglacial in Western Europe (=Likhvin Interglacial in East- ern Europe), coinciding with the Marine Isotope Stage 11 (405-340 ka BP). Mousterian layer 3a is dated by radiocarbon to $44,150 \pm 2,400 / 1,850$ (Gr-6079).

Kudaro 3 Cave, which is situated somewhat lower than Kudaro 1 Cave, contains cave sediments mostly consisting of loam with limestone fragments. The loam color changes from yellow-brown at the bottom to dark gray in the upper part. A small number of the Acheulean artifacts were recovered from layers 5-8, and Mousterian artifacts were recovered from layers 3-4 (Lioubine, 1998).

The geomorphologic data suggest that Kudaro 3 Cave was first opened for occupation by erosion which occurred approximately 50,000-100,000 years after the opening of Kudaro 1 Cave (Nesmeyanov, 1999). The contact zone of the Acheulean and Mousterian layers is dated by two RTL-dates to $252,000 \pm 51,000$ years and $245,000 \pm 49,000$ years (Lioubine, 1998), which suggest a considerable time gap between their deposition in the cave.

The examined material includes more than 850 remains of canids. Bone fragments and isolated teeth are predominant. This material is stored in the Zoological Institute, Russian Academy of Sciences (ZIN) in St. Petersburg. For comparison, the fossil and recent collection of ZIN and Pleistocene Canidae material at other museums (see Institutional abbreviations below) has been used.

The bones and teeth were measured by calipers with accuracy of $0.5 \mathrm{~mm}$. Limb bones were measured according to von den Driesch (1976). Tooth dimensions were processed with use of Factor Analysis from STATISTICA 6.0.

Institutional abbreviations: AUT - Aristotle University, Thessaloniki, Greece; CBUL - Claude Bernard University Lyon 1, Villerbann, France; GMY Geological Museum of the Diamond and Precious Metals Geology Institute, Siberian Branch of Russian Academy of Sciences, Yakutsk, Russia; NMM - Naturhistorisches Museum, Mainz, Germany; IGPR — Institute of Geology and Paleontology, "La Sapienza" University, Roma, Italy; ISAK - Institute of Systematics and Evolution of Animals, Krakow, Poland; IZKM - Institute of Zoology, Academy of Sciences of Moldova, Kishinev, Moldova Republic; MG - Museo Geominero, Instituto Geológico y Minero de España, Madrid, Spain; MHP — Musée de l'Homme, Paris, France; MMBA - Moravsky Museum (Anthropos), Brno, Czech Republic; MNHN — Muséum national d'Histoire naturelle, Paris, France; NHM - Natural History Museum, London, Great Britain; USNM - United States National Museum, Washington DC, USA; ZIN - Zoological Institute, Russian Academy of Sciences, St. Petersburg, Russia.

Measurements. Dental measurements: $L$ - greatest length, $W$ - greatest width, Lpa — length of paracone, Lpad - length of paraconid, Ltald - talonid length. Bone measurements (von den Driesch, 1976): cervical vertebrate: $B F C d$ - breadth of the caudal 
articular surface, $B F C r$ - breadth of the cranial articular surface, Bpacd - breadth across the Processus articularis caudalis, $H$ - height, $L A P a$ - length of the arch including the processus articularis caudalis, $L C D e$ - length in the region of the corpus including the dens, $S B V$ - smallest breadth of the vertebra; limb bones: $B c f$ - breadth of cuboid facet, $B d$ - breath of the distal end, $B G$ - breadth of the glenoid cavity, $B p$ - breadth of the proximal end, $B P C$ - breadth across the coronoid process, $D C$ - depth of the Caput femoris, $D d$ - depth of the proximal end, $D p$ - depth of the proximal end, DPA - depth across the Processus anconaeus, $G B$ - greatest breadth, $G L$ - greatest length, GLP — greatest length of the glenoid process, $L A$ - length of the acetabulum including the lip, $L A R$ - length of the acetabulum on the rim, $S B$ smallest breadth of the shaft of ilium, $S D$ - smallest breadth of the diaphysis in the middle part, $S D O$ smallest depth of olecranon, $S H$ - smallest height of the shaft of ilium, $S L C$ - smallest length of the neck of the scapula.

\section{Systematics}

\section{Family Canidae Fisher de Waldheim, 1817 Genus Canis Linnaeus, 1758 \\ $\dagger$ Canis arnensis Del Campana, 1913}

Referred specimens. Middle Pleistocene, Kudaro 1 Cave: right maxilla with P2-M2 (ZIN 31889-1, layer 5, horizon 3, 1959); three right upper canine (ZIN 31889-2, layer 5, horizon 3, 1959; 36609, layer 5, horizon 6, 1959; 36612, layer 5c, horizon 2, 1980); right P3 (ZIN 36607-2, layer 5, horizon 4, 1959); left M2 (ZIN 36607-3, layer 5, horizon 4, 1959); fragment of left mandible with p2-p4 (ZIN 36611, layer X, horizon 2, 1978); right lower canine (ZIN 36610, layer 5c, horizon 2, 1978); two right p3 (ZIN 36605, layer 5, horizon 3, 1959; 36608, layer 5, horizon 5, 1959); right p4 (ZIN 36607-1, layer 5, horizon 4, 1959); fragment of p4 (ZIN 36604, layer 5, horizon 4, 1958); two right m2 (ZIN 36607-4, layer 5, horizon 4, 1959; 36614, layer 5c, horizon 4, 1984); proximal fragment of radius (ZIN 36613, layer 5c, horizon 1, 1984); proximal fragment of right Mc2 (ZIN 36606-2, layer 5, horizon 4, 1959); left talus (ZIN 36603-1, layer 5, horizon 2, 1957); right calcaneus (ZIN 36606-1, layer 5, horizon 4, 1959); os tarsi centrale (ZIN 36606-3, layer 5, horizon 4, 1959); first phalanx and tooth fragments. Kudaro 3: distal fragment of left humerus (ZIN 36615, layer 8, 1981). Total 23 fossil remains.

Description. Maxilla with P2-M2 (ZIN 31889-1; Fig. 1A) of the fossil small canid was found in the basal layer 5 of the Kudaro 1 Cave, containing the late Acheulean stone industries. Because in the tooth dimensions ZIN 31889-1 resembles a coyote maxilla, it was first determined as Canis ex gr. latrans Say, 1823 (Baryshnikov, 1986).

Judging from the length of upper tooth row, the muzzle of the small fossil canid was elongated. The infraorbital foramen is located over the border between $\mathrm{P} 3$ and $\mathrm{P} 4$ (in the recent coyote $C$. latrans, it is usually located over P3). The angle between long axis of the carnassial tooth P4 and that of molar row M1-M2 is more obtuse than in the recent $C$. latrans. The long axis of P4 is directed labial to P3, instead of crossing this tooth as in the recent $C$. latrans. Such position of the upper carnassial tooth is observed in several skulls of the recent jackals $C$. adustus Sundevall, 1847 (ZIN 14689) and C. aureus (ZIN 18727).

The cheek teeth are moderately worn. The anterior premolars are narrow, being spaced more widely in comparison with the recent coyote. The diastema between P2 and P3 is $1.5 \mathrm{~mm}$ and that between P3 and P4 is $4.0 \mathrm{~mm}$. The carnassial tooth and upper molars are crowded.

There is the alveolus of P1. P2 is trenchant, with very small posterior cusp and lingual cingulum. P3 is larger as compared to P2, the former bearing welldeveloped posterior cusp, which is more robust than in the recent $C$. latrans. The lingual border of $\mathrm{P} 3$ has a cingulum forming a small prominence at the crown posterior end.

The upper carnassial tooth $\mathrm{P} 4$ is shorter than the length of upper molar row M1-M2. Paracone is pronounced, its anterior margin bearing a sharp ridge. Metacone and metastyle are comparatively longer than those in the recent $C$. latrans. Carnassial notch is deep. The lingual prominence of the tooth crown is robust; its root is oblique, exceeding the bounds of the crown outside. The protocone is blunt, being not beyond the anterior end of the paracone. The posterior part of lingual border of the crown has an inconspicuous cingulum.

The paracone and metacone of M1 are almost equal in length, the paracone being a little longer and higher. The labial cingulum is developed, which is especially pronounced across the paracone. Protocone, metaconule, and hypocone are well marked. The protoconule is very weak. The trigonid basin is somewhat wider as compared to that in the recent coyote. The anterior margin of the tooth reveals a well-developed cingulum merging with the hypocone. The latter cusp is only slightly lower than the protocone and resembles the entire ridge with two small facets of wear (signs of poor-marked apices).

The anterior margin of the M2 crown is salient; the posterior margin has a pronounced median depression, which is shallower in comparison with the recent jackal C. aureus. Paracone and metacone are low, situating almost on the same line, which may be drawn through the apices of protocone and metacone of M1. The labial cingulum is well-developed. The metacone is only slightly smaller than paracone. Trigon is wide, with a shallow basin. Postprotocrista is present, metaconule is absent. Hypocone is well marked. There is a cingulum along the anterior side of the tooth crown, which extends onto the base of hypocone.

The length of tooth row P2-M2 allows comparison of the fossil maxilla ZIN 31889-1 with North American small-size canid-species: the recent coyote $C$. latrans and fossil coyote-like $\operatorname{dog} C$. lepophagus Johnston, 

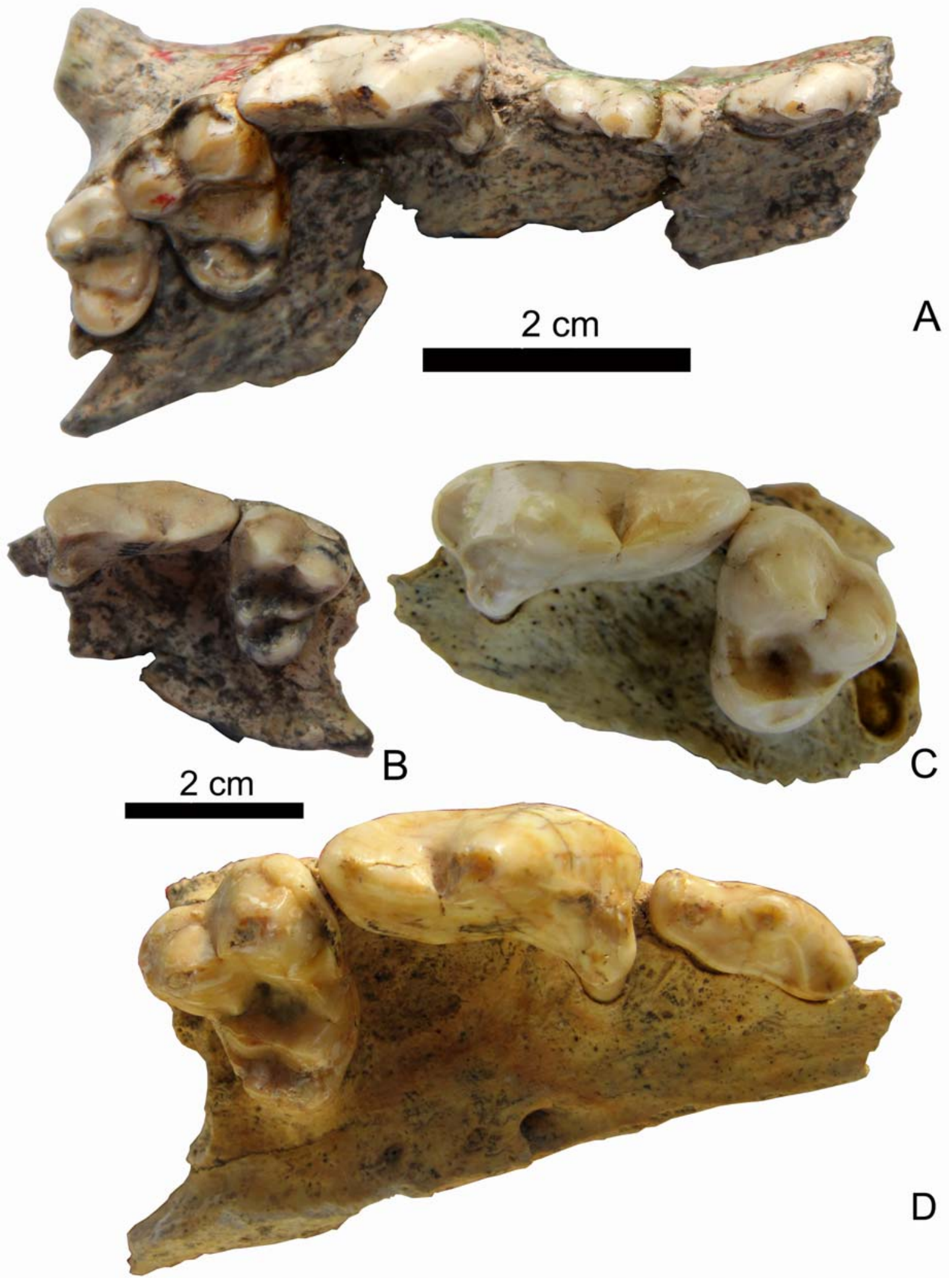

Figure 1. Maxilla fragments Canis latrans kudarensis ssp. nov. (A) and C. mosbachensis (B) from Kudaro 1 Cave and Cuon alpinus caucasicus (C) and Canis lupus (D) from Kudaro 3; occlusal view. A - ZIN 31889-1, holotype; B — ZIN 36621; C — ZIN 34343; C — ZIN 31880. 
Table 1. Measurements (in mm) of maxilla in small-sized Canis.

\begin{tabular}{|c|c|c|c|c|c|c|c|c|}
\hline \multirow{3}{*}{ Measurements } & $\begin{array}{l}\text { C. arnensis } \\
\text { kudarensis } \\
\text { subsp. nov. }\end{array}$ & C. accitanus & C. senezensis & C. lepophagus & \multicolumn{4}{|c|}{ C. latrans } \\
\hline & $\begin{array}{c}\text { Kudaro } 1 \\
\text { Cave, }\end{array}$ & $\begin{array}{l}\text { Fonelas P1, } \\
\text { Spain, Early }\end{array}$ & $\begin{array}{c}\text { Senèz, France, } \\
\text { Early }\end{array}$ & $\begin{array}{l}\text { Harrell Ranch, } \\
\text { Cita Canyon, }\end{array}$ & \multicolumn{4}{|c|}{$\begin{array}{c}\text { North America, } \\
\text { Recent (males and females) }\end{array}$} \\
\hline & $\begin{array}{l}\text { ZIN } 31889, \\
\text { holotype }\end{array}$ & $\begin{array}{c}\text { MG FP1- } \\
\text { 2001-0434, } \\
\text { holotype } \\
\text { (Garrido, } \\
\text { Arribas, 2008) }\end{array}$ & $\begin{array}{c}\text { CBUL } \\
210987 \\
\left(=\begin{array}{l}\text { FSL 3736), } \\
\text { holotype }\end{array}\right.\end{array}$ & $\begin{array}{c}\text { USNM } 181495, \\
\text { cast }\end{array}$ & $n$ & $\lim$ & M & SD \\
\hline Length P1-M1 & & & 70.0 & & & & & \\
\hline Length P2-M2 & 61.0 & & & 59.7 & 8 & $56.0-68.0$ & 62.77 & 4.38 \\
\hline Length P1-P4 & & 51.3 & 59.1 & & & & & \\
\hline Length P2-P4 & 45.95 & & & 43.1 & & & & \\
\hline Length M1-M2 & 19.4 & 19.9 & & 20.0 & 34 & $18.1-23.0$ & 20.72 & 1.16 \\
\hline \multicolumn{9}{|c|}{ Teeth } \\
\hline P2 L & 10.8 & 10.9 & 10.7 & 9.4 & 31 & $9.0-13.0$ & 10.83 & 0.88 \\
\hline $\mathrm{W}$ & 4.5 & 4.2 & 3.8 & 4.3 & 32 & $3.1-4.9$ & 4.06 & 0.39 \\
\hline P3 L & 12.2 & 11.6 & 12.0 & 12.2 & 31 & $10.4-13.7$ & 12.21 & 0.99 \\
\hline $\mathrm{W}$ & 4.6 & 4.5 & 4.5 & 4.4 & 31 & $3.3-8.2$ & 4.56 & 0.86 \\
\hline P4 L & 18.3 & 18.5 & 19.0 & 17.8 & 35 & $16.4-22.5$ & 19.53 & 1.24 \\
\hline Lpa & 11.6 & & 12.0 & 10.25 & 35 & $10.4-14.1$ & 12.50 & 0.85 \\
\hline W & 9.7 & 8.6 & 9.9 & 9.1 & 35 & $7.8-11.1$ & 9.78 & 0.79 \\
\hline M1 L & 11.6 & 12.5 & 12.0 & 11.4 & 35 & $10.8-14.3$ & 12.96 & 0.83 \\
\hline Lpa & 6.0 & & 6.7 & 6.25 & 34 & $5.6-7.5$ & 6.70 & 0.44 \\
\hline $\mathrm{W}$ & 15.1 & 14.4 & 14.7 & 14.9 & 35 & $13.4-17.7$ & 15.75 & 1.02 \\
\hline M2 Length & 7.45 & 7.2 & & 7.35 & 36 & $6.4-8.6$ & 7.52 & 0.55 \\
\hline $\mathrm{W}$ & 10.2 & 9.5 & & 10.1 & 36 & $9.2-12.1$ & 10.93 & 0.79 \\
\hline
\end{tabular}

1938 (Tab. 1). At the same time, the length of P2-M2 and the length of $\mathrm{P} 2-\mathrm{P} 4$, of the specimen from Kudaro Cave 1 exceed the recent $C$. aureus from the Caucasus. Length M1-M2 and length P4 is smaller than these measurements in C. arnensis from Gerakarou in Grecce (Koufos, 1987).

Notably, the isolated upper canine (ZIN 31889-2) was recovered near the maxilla ZIN 31889-2, both presumably belonging to the same individual. Dimensions of this canine (length $8.5 \mathrm{~mm}$, width $5.4 \mathrm{~mm}$ ) are typical of the female of recent coyote. There are two other upper canines (ZIN 36609, 36612) of similar size, which were found in the middle and upper parts of the cave layer 5 . These specimens resemble in measurements the canine of the fossil canid C. lepophagus (USNM 181495) from Harrell Ranch in USA (Tab. 2). Measurements of Kudaro specimens are also fall into the limits of size variation of upper canines in the recent C. latrans (length $7.8-10.5 \mathrm{~mm}$, width $4.5-6.2 \mathrm{~mm}$, $\mathrm{n}=30$ ).

Two isolated upper cheek teeth from middle part of layer 5, P3 (ZIN 36607-2) and M2 (ZIN 36607-3), were assigned to a coyote-like canid, since their length and width correspond to dimensions of intact P3 and M2 from the maxilla ZIN 31889-1 (Tab. 3). P3 has rather small posterior cusp. Postprotocrista of M2 is weak, metaconule is absent on this tooth and its hypocone is large.
Among West European small fossil canids, similar tooth measurements were recorded in coyote-like species: C. senezensis from locality Senéz in France (Martin, 1973) and C. accitanus from locality Fonelas P1 in Spain (Garrido, Arribas, 2008) (see Tab. 1). Both localities are noticeably older than Kudaro 1 Cave, their age being ascertained near 1.8 Ma (Brugal, BoudadiMaligne, 2011) or near 2.0 Ma for Senéz (biochron MNQ18; Palombo \& Valli, 2004; Delson et al., 2006). The teeth of $C$. arnensis known from the Early Pleistocene sites in European Mediterranean are only slightly larger.

The upper cheek teeth have been processed using the discriminant analysis of 12 measurements shown in Tab. 1. The analysis incorporated 5 samples: Canis aureus, Caucasus, Recent $(\mathrm{n}=12) ;$ C. latrans, Recent $(\mathrm{n}=37)$; C. lupus, Caucasus, Late Pleistocene and Recent ( $\mathrm{n}=44) ; C$. mosbachensis from Kudaro caves, Middle Pleistocene $(\mathrm{n}=3)$ and from Stránská skála, Czech Republic, Middle Pleistocene $(\mathrm{n}=12)$; as well as individual specimens of C. lepophagus, Harrell Ranch, USA, Late Pliocene, C. senezensis, Senéz, France, Early Pleistrocene, and the maxilla ZIN 31889-1 from Kudaro 1 Cave. On the resulted scatter plot, the samples of C. latrans, C. mosbachensis and C. lupus are distinctly diverged by the Root 1 , which involves the length of paracone $\mathrm{M} 1$, length of paracone of $\mathrm{P} 4$, length of P4, and length of M1 (83.6\% of dispersion) (Fig. 2). 
Table 2. Measurements (in mm) of upper and lower canines Canis.

\begin{tabular}{|c|c|c|c|c|c|}
\hline \multirow{2}{*}{ Localities } & \multirow{2}{*}{ Museum number } & \multicolumn{2}{|c|}{$\mathrm{C} 1$} & \multicolumn{2}{|c|}{ c1 } \\
\hline & & $\mathrm{L}$ & $\mathrm{W}$ & $\mathrm{L}$ & $\mathrm{W}$ \\
\hline \multicolumn{6}{|c|}{ C. lepophagus } \\
\hline Harrell Ranch, Cita Canyon, USA & USNM 181495 , cast & 9.7 & 5.4 & & \\
\hline \multicolumn{6}{|c|}{ C. arnensis kudarensis ssp. nov. } \\
\hline \multirow{4}{*}{ Kudaro1, layer 5} & ZIN 31889 & 8.5 & 5.4 & & \\
\hline & ZIN 36609 & 8.6 & 5.7 & & \\
\hline & ZIN 36612 & 9.6 & 5.9 & & \\
\hline & ZIN 36610 & & & 7.9 & 5.9 \\
\hline \multicolumn{6}{|c|}{ C. mosbachensis } \\
\hline \multicolumn{6}{|c|}{ Caucasus } \\
\hline \multirow{5}{*}{ Kudaro1, layer 5} & ZIN 36624 & 9.7 & 6.4 & & \\
\hline & ZIN 36625 & & & 9.6 & 7.4 \\
\hline & ZIN 36630-1 & & & 11.0 & 6.6 \\
\hline & ZIN 36619 & & & 12.5 & 7.2 \\
\hline & ZIN 36620-1 & & & 10.2 & 6.6 \\
\hline Kudaro 3, layer 8a & ZIN 32023-2 & & & 11.8 & 7.9 \\
\hline \multicolumn{6}{|c|}{ Europe } \\
\hline Perrier, France & $\mathrm{MNHN} \mathrm{n} / \mathrm{n}$ & & & 11.0 & 6.5 \\
\hline No locality, Czech Republic & $\mathrm{ZIN} \mathrm{n/n}$ & & & 10.7 & 7.5 \\
\hline No locality, Czech Republic & $\mathrm{ZIN} \mathrm{n/n}$ & & & 10.6 & 6.5 \\
\hline \multicolumn{6}{|c|}{ C. lupus } \\
\hline \multicolumn{6}{|c|}{ Caucasus } \\
\hline Kudaro 1, layer 4 & ZIN 36649-1 & 11.2 & 7.6 & & \\
\hline \multirow{3}{*}{ Kudaro 3, layer 4} & ZIN 36651 & & & 11.8 & 8.2 \\
\hline & ZIN 36652 & & & 11.3 & 7.4 \\
\hline & ZIN 36657-1 & & & 12.1 & 7.4 \\
\hline Kudaro 3, layer 3 & ZIN 36654 & 12.0 & 7.2 & & \\
\hline \multirow{5}{*}{ Binagady } & ZIN 22384-53 & 12.0 & 7.8 & & \\
\hline & ZIN 22384-46 & & & 14.5 & 10.6 \\
\hline & ZIN 22384-47 & & & 14.0 & 9.5 \\
\hline & ZIN 22384-51 & & & 12.7 & 9.0 \\
\hline & ZIN 24408-1 & & & 12.7 & 8.3 \\
\hline M. Voronzovskaya, layer 3 & ZIN 31978 & & & 14.1 & 9.4 \\
\hline \multicolumn{6}{|c|}{ Europe } \\
\hline \multirow{5}{*}{ Kent Caverns, England } & NHM 736 & 14.1 & 8.8 & & \\
\hline & NHM 850 & 14.7 & 9.5 & & \\
\hline & NHM 16755 & 14.1 & 8.3 & & \\
\hline & NHM 15636 & & & 13.2 & 8.1 \\
\hline & NHM 831 & & & 13.2 & 9.1 \\
\hline \multirow{3}{*}{ Gibraltar } & NHM 12333 & & & 13.6 & - \\
\hline & NHM 12333 & & & 11.9 & 7.8 \\
\hline & NHM 12333 & & & 13.1 & 8.3 \\
\hline Kostenki, European Russia & ZIN 36233 & 13.4 & 9.4 & & \\
\hline Alasea River, Yakutia, Russia & GMY 5171 & & & 14.6 & 9.1 \\
\hline
\end{tabular}

Therefore, the species differ by metric characteristics of the upper carnassial tooth and first upper molar. $C$. aureus, revealing similar dimensions of upper cheek teeth, is segregated from $C$. latrans by Root 2, which predominantly embraces the length of M1 and length of P3 (9.3\% of dispersion). Fossil coyote-like dogs, $C$. lepophagus and $C$. senezensis, do not exceed the range of the sample of $C$. latrans, both fossil taxa locating closer to one another and to C. aureus than to the small canid from Kudaro 1 Cave.

The contents of an erosional lens between layers 4 and 5 (lens " $X$ ") in Kudaro 1 Cave, containing mixed
Acheulean and Mousterian stone industries (Lioubine, 1998), revealed a fragment of right mandible with $\mathrm{p} 2$, p3 and a fragment of p4 (ZIN 36611; Fig. 3I, J). The alveolus of $\mathrm{p} 1$ is absent. The mandible is robust, belonging to an adult. By the length and thickness at the level of p4 $(8.5 \mathrm{~mm})$, it corresponds to the large recent coyote C. latrans (ZIN 971); however, the premolar row in the fossil specimen is shorter. The distance from the posterior margin of the canine alveolus to the anterior margin of alveolus of $\mathrm{m} 1$ constitutes $41.4 \mathrm{~mm}$ compared with $50.9 \mathrm{~mm}$ in ZIN 971. The mental foramina are distanced from each other, the first foramen 
Table 3. Measurements (in mm) of upper cheek teeth Canis.

\begin{tabular}{|c|c|c|c|c|c|c|c|c|c|c|c|}
\hline \multirow{2}{*}{ Localities } & \multirow{2}{*}{ Museum number } & \multicolumn{2}{|c|}{ P1 } & \multicolumn{2}{|c|}{ P2 } & \multicolumn{2}{|c|}{ P3 } & \multicolumn{2}{|c|}{ M1 } & \multicolumn{2}{|c|}{ M2 } \\
\hline & & $\mathrm{L}$ & $\mathrm{W}$ & $\mathrm{L}$ & $\mathrm{W}$ & $\mathrm{L}$ & $\mathrm{W}$ & $\mathrm{L}$ & $\mathrm{W}$ & $\mathrm{L}$ & $\mathrm{W}$ \\
\hline \multicolumn{12}{|c|}{ C. arnensis kudarensis ssp. nov. } \\
\hline \multirow{2}{*}{ Kudaro 1} & ZIN 36607-2 & & & & & 11.9 & 4.3 & & & & \\
\hline & ZIN 36607-3 & & & & & & & & & 7.4 & 10.2 \\
\hline \multicolumn{12}{|c|}{ C. mosbachensis } \\
\hline \multicolumn{12}{|c|}{ Caucasus } \\
\hline \multirow{6}{*}{ Kudaro 1, layer 5} & ZIN 36631 & 6.4 & 4.1 & & & & & & & & \\
\hline & ZIN 36640 & 7.1 & 4.8 & & & & & & & & \\
\hline & ZIN 36626 & & & & & 12.7 & 5.6 & & & & \\
\hline & & & & & & & & & & & \\
\hline & & & & & & & & & & & \\
\hline & & & & & & & & & & & \\
\hline \multicolumn{12}{|c|}{ Europe } \\
\hline \multirow{4}{*}{$\begin{array}{l}\text { Westbury Quarry } \\
\text { Cave, England }\end{array}$} & NHM 33529 & & & & & 14.3 & 5.9 & & & & \\
\hline & NHM $1 / 350$ & & & & & 13.8 & 6.0 & 14.1 & 16.7 & & \\
\hline & NHM 405 & & & & & & & 12.7 & 15.7 & & \\
\hline & NHM 78/9 & & & & & & & 12.8 & 16.8 & & \\
\hline \multirow{9}{*}{$\begin{array}{l}\text { Stránska skála, } \\
\text { Czech Republic }\end{array}$} & MMBA 1378 & & & & & 16.0 & 6.8 & & & & \\
\hline & MMBA Sch181 & & & & & 13.3 & 5.5 & & & & \\
\hline & MMBA 1345 & & & & & & & 14.1 & 16.8 & & \\
\hline & MMBA 1378 & & & & & 16.0 & 6.8 & & & & \\
\hline & MMBA 1568 & & & & & & & 14.2 & 18.1 & & \\
\hline & MMBA 1569 & & & & & & & & & 8.7 & 11.9 \\
\hline & MMBA 1587 & & & & & & & 13.6 & 16.4 & & \\
\hline & MMBA Kn40 & & & & & & & 13.0 & 16.0 & & \\
\hline & MMBA n/n & & & & & & & 14.1 & 16.8 & & \\
\hline \multicolumn{12}{|c|}{ C. lunellensis } \\
\hline \multirow{3}{*}{ Kudaro 3, layer 6} & ZIN 36646 & 6.9 & 5.0 & & & & & & & & \\
\hline & ZIN 31884-5 & & & 11.5 & 5.2 & & & & & & \\
\hline & ZIN 36647 & & & & & 13.0 & 6.3 & & & & \\
\hline \multicolumn{12}{|c|}{ C. lupus } \\
\hline \multirow{3}{*}{ Kudaro 3, layer 4} & ZIN 31882-1 & & & & & & & 16.1 & ca18.9 & & \\
\hline & ZIN 31882-2 & & & & & & & 15.8 & 18.8 & & \\
\hline & ZIN 31883-3 & & & & & & & & & 8.5 & 11.9 \\
\hline
\end{tabular}

situating below the anterior margin of $\mathrm{p} 2$ and second below the posterior margin of $\mathrm{p} 3$. The premolars $\mathrm{p} 2-\mathrm{p} 4$ are very narrow, blade-like, not differing by their length from those in the recent $C$. latrans (Tab. 4). The posterior margin of $\mathrm{p} 3$ bears supplementary cuspid, which is absent on p2. The premolar p3 is located lower than premolars $\mathrm{p} 2$ and p4. By its shortness, ZIN 36611 from Kudaro 1 Cave resembles the mandible of jackal ( $C$. aureus); though, the mental foramina of jackal are approximate and its premolars are markedly wider.

Principal components analysis was performed for 5 samples on the basis of 8 mandible measurements given in Tab. 4. The analysis included samples of recent coyote Canis latrans, North America $(n=5)$, recent jackals: C. aureus, Caucasus ( $\mathrm{n}=16)$, C. mesomelas Schreber, 1775, East Africa $(\mathrm{n}=4)$, and C. adustus, East Africa $(n=2)$, as well as ZIN 36611. In the factor space samples of jackals were divided by Factor 1, which includes all measurements except the mandible height beyond p2 (76.5\% of dispersion). Jackals were separated from the coyote by Factor 2, including three measurements: length of p2-p4, width of p3, and width of p4 (9.6\% of dispersion). On the scatter plot, the mandible fragment from Kudaro 1 Cave placed near the sample of $C$. latrans and is clearly separated from all jackal species (Fig. 4).

Within the Kudaro collection, isolated lower teeth are represented by the canine (ZIN 36610) whose parameters are characteristic of $C$. latrans. Also found were lower premolars p3 and p4 (Fig. 3M, N) which correspond in their length and width to the same teeth of the recent coyote (Tab. 5) and reveal well-developed posterior cups. Meanwhile, the fragment of premolar p4 (ZIN 36604) is widened in the posterior portion, as in jackal (C. aureus), resembling this species in the width of the tooth crown.

Two lower molars $\mathrm{m} 2$, both right ones, are determined as belonging to the Kudaro small canid (Tab. 6). 


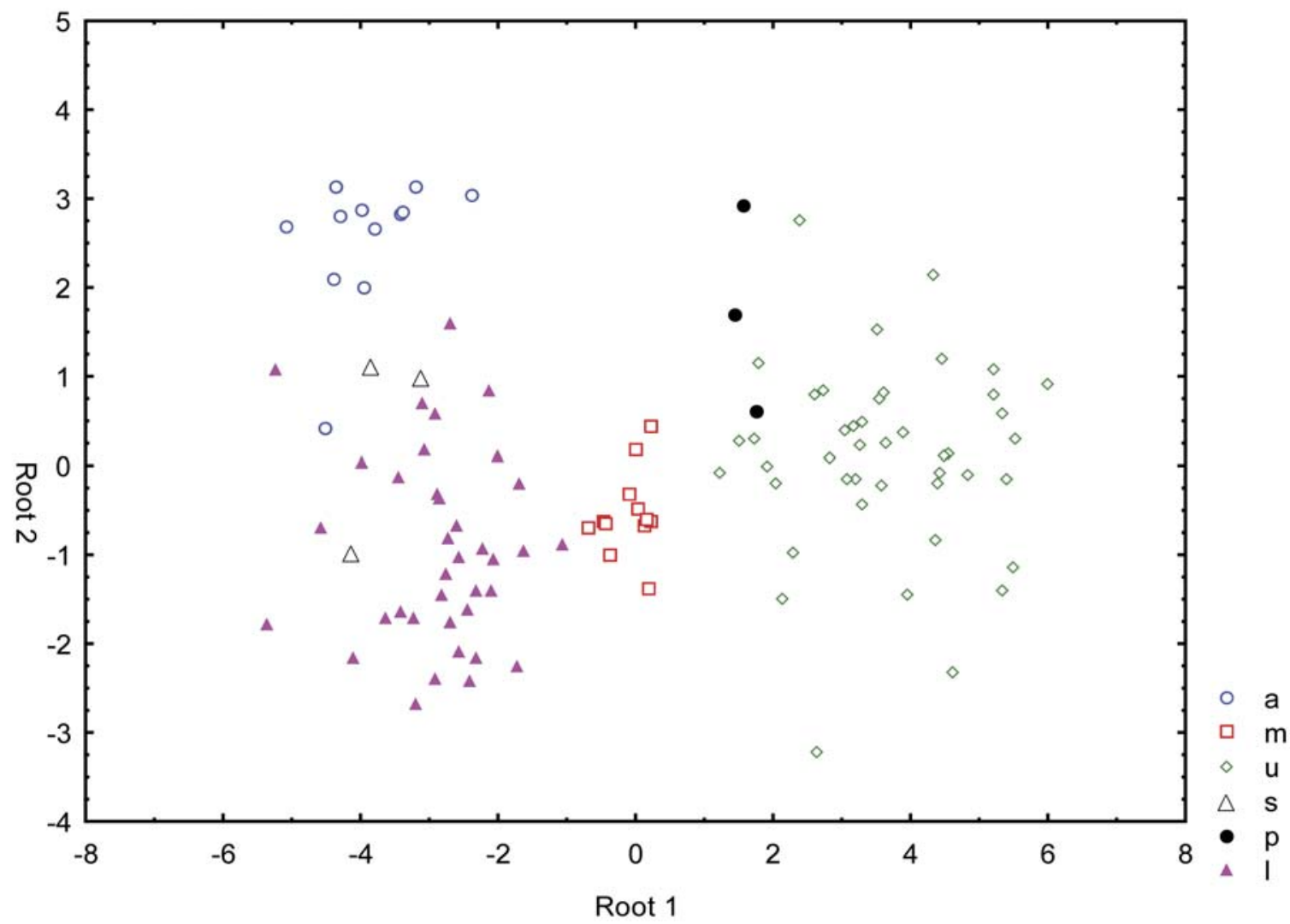

Figure 2. Scatter plot of canonical scores of Root 1 and Root 2 from discriminant analysis for upper tooth row P2-M2 in Canis. a - C. aureus, Recent; $1-C$. latrans, Recent; $\mathrm{m}-C$. mosbachensis, Stránská skála; $\mathrm{p}-C$. mosbachensis, Kudaro 1 Cave; s - C. lepophagus and C. senezensis (above), and C. arnensis kudarensis ssp. nov. (below); u - C. lupus, Caucasus, Late Pleistocene and Recent.

The fossil specimens are wider in comparison with teeth of the recent $C$. latrans owing to the more pronounced development of the labial cingulid. This character aligns them with the teeth of $C$. aureus. The metaconid and protoconid are approximately equal in size and exhibit equal height. Both Kudaro specimens are smaller compared to the $\mathrm{m} 2$ of $C$. mosbachensis, whose sample from Stránská skála in Czech Republic shows length variation $9.4 \mathrm{~mm}$ to $10.9 \mathrm{~mm}$ and of the width variation $6.7 \mathrm{~mm}$ to $7.8 \mathrm{~mm}$ (Tab. 6).

Several limb bones of a small fossil dog, which were found in Kudaro 1 Cave, show no difference with those of the recent gold jackal C. aureus (Tab. 7). The proximal end of radius (ZIN 36613) is only slightly

Tables 4. Measurements (in mm) of mandibles in small Canis.

\begin{tabular}{|c|c|c|c|c|c|c|c|}
\hline \multirow{3}{*}{ Measurements } & $\begin{array}{c}\text { C. arnensis kudarensis } \\
\text { ssp. nov. }\end{array}$ & \multicolumn{2}{|c|}{ C. latrans } & \multicolumn{2}{c|}{ C. aureus } & C. adustus & C. mesomelas \\
\cline { 2 - 8 } & $\begin{array}{c}\text { Kudaro 1 Cave, } \\
\text { Middle Pleistocene }\end{array}$ & \multicolumn{2}{|c|}{ USA, recent } & \multicolumn{2}{c|}{ Caucasus, recent } & $\begin{array}{c}\text { Africa, } \\
\text { recent }\end{array}$ & Africa, recent \\
\cline { 2 - 9 } & ZIN 36611 & $\begin{array}{c}\text { ZIN } \\
971\end{array}$ & $\begin{array}{c}\text { ZIN } \\
5943\end{array}$ & $\begin{array}{c}\text { ZIN } \\
16899\end{array}$ & $\begin{array}{c}\text { ZIN } \\
18721\end{array}$ & ZIN 14689 & ZIN 9330 \\
\hline Length p2-p4 & ca32.1 & 39.7 & 34.3 & 31.3 & 30.7 & 25.1 & 30.1 \\
\hline Height before p3 & 15.1 & 15.3 & 14.3 & 15.2 & 13.6 & 12.9 & 14.0 \\
\hline \multicolumn{7}{|c|}{ Teeth } \\
\hline p2 L & 8.6 & 10.1 & 8.9 & 9.2 & 8.8 & 6.6 & 7.7 \\
\hline W & 3.2 & 4.8 & 3.6 & 4.1 & 3.9 & 2.7 & 3.4 \\
\hline p3 L & 10.5 & 11.6 & 9.7 & 10.4 & 9.6 & 7.1 & 8.7 \\
\hline W & 3.7 & 4.7 & 3.8 & 4.4 & 4.0 & 3.2 & 3.7 \\
\hline p4 L & ca11.0 & 12.3 & 11.0 & 11.4 & 11.1 & 8.6 & 9.8 \\
\hline W & ca4.5 & 5.9 & 4.6 & 5.5 & 4.8 & 3.9 & 4.4 \\
\hline
\end{tabular}




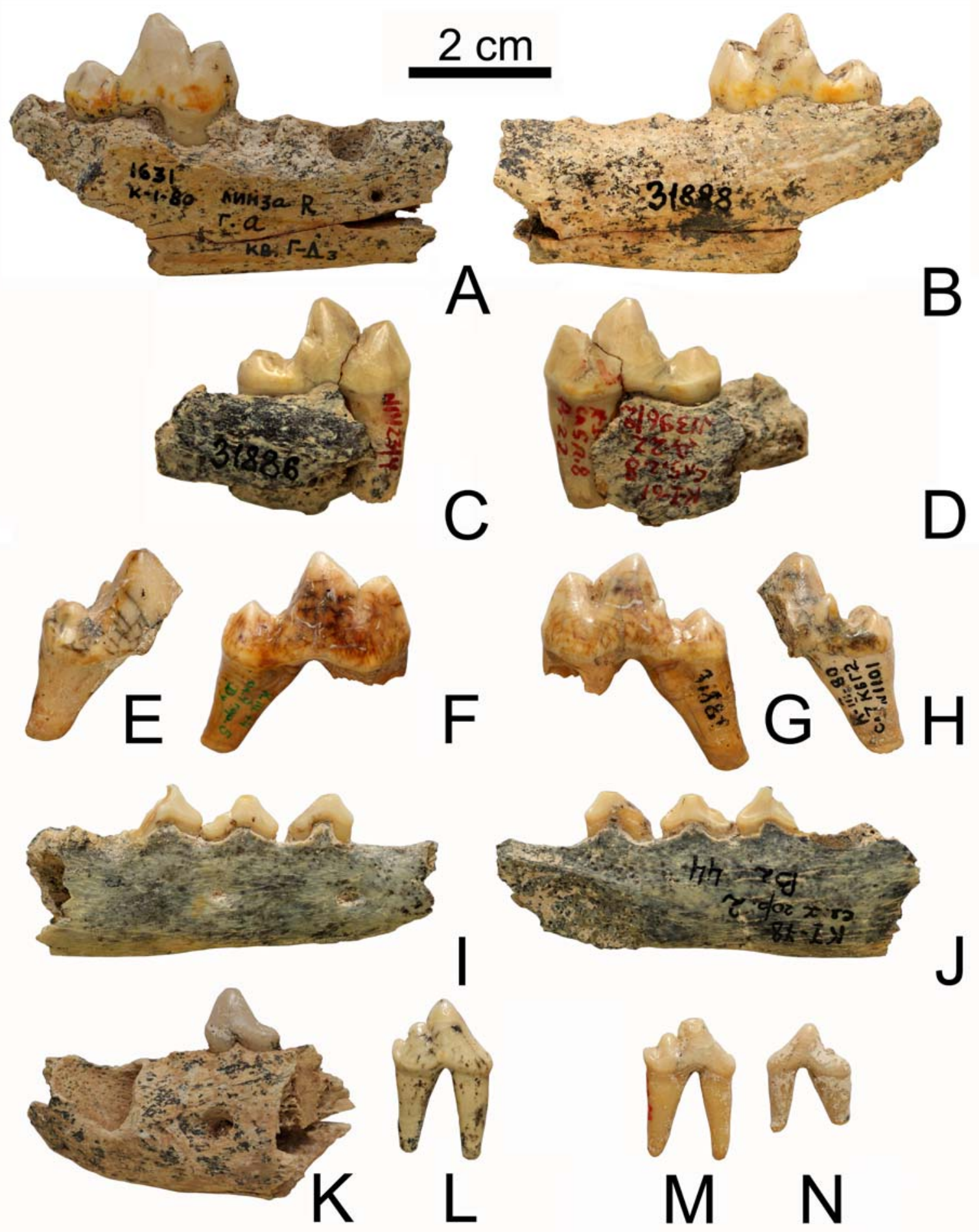

Figure 3. Mandible fragments and lower cheek teeth of Canis arnensis kudarensis ssp. nov. (I, J, M, N), C. mosbachensis (A$\mathrm{D}, \mathrm{K}-\mathrm{L})$, C. lunellensis $(\mathrm{E}, \mathrm{H})$ and $C$. lupus $(\mathrm{F}, \mathrm{G})$ from Kudaro caves; labial $(\mathrm{A}, \mathrm{D}, \mathrm{E}, \mathrm{F}, \mathrm{I}, \mathrm{K}-\mathrm{N})$ and lingual $(\mathrm{B}, \mathrm{C}, \mathrm{G}, \mathrm{H}, \mathrm{J})$ views.

A, B — ZIN 31888-1; C, D — ZIN 31886; E, H — ZIN 36645; F, G — ZIN 31881; I, J — ZIN 36611; K — ZIN 32023-1; L — 36629; M - ZIN 36607-1; N - ZIN 36607-2. 


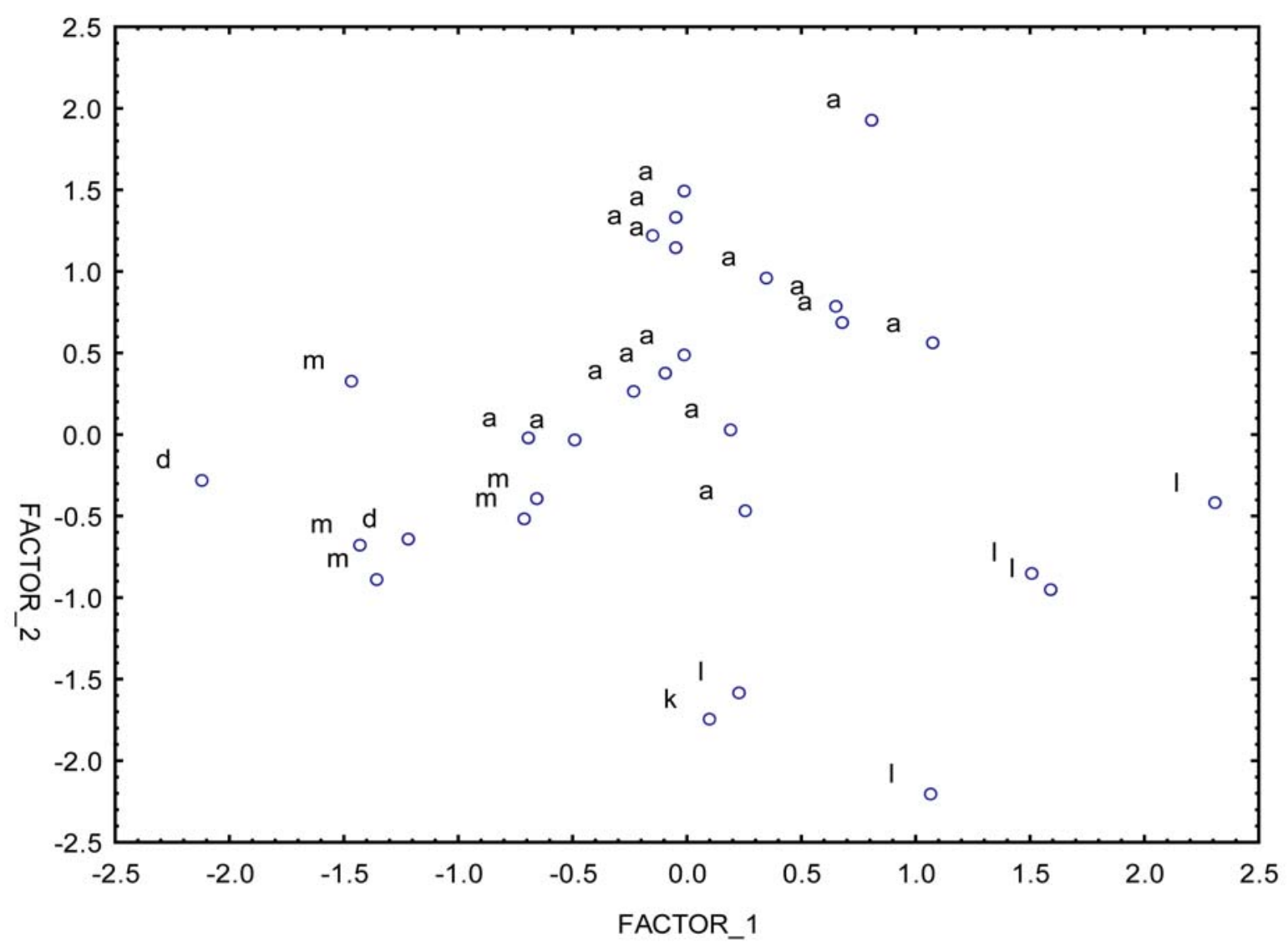

Figure 4. Plot of factor scores of Factor 1 and Factor 2 from principal components analysis of mandible in Canis. a - C. aureus, Caucasus, Recent; d - C. adustus, Recent; $\mathrm{k}-$ C. arnensis kudarensis ssp. nov., Kudaro 1 Cave; 1 - C. latrans, Recent; $\mathrm{m}-$ C. mesomelas, Recent.

narrower than that of $C$. lepophagus from Red Light Bolson in USA (Kurtén, 1974). Left talus (ZIN ZIN 36603-1) and right calcaneus (ZIN 36606-1) resemble in the length and width these bones of the recent $C$. aureus, the caput tali being, however, shorter and collum tali narrower in the fossil talus.

The only bone of this small canid has been found in Kudaro 3 Cave, in layer 8. This is a distal fragment of the humerus (ZIN 36615), whose width is similar to that in the recent jackal $C$. aureus.

The study reveals that the small canid from Kudaro caves resembles the recent coyote ( $C$. latrans) by the dimensions of upper and lower cheek teeth, differing significantly from jackal (C. aureus), which provides a possibility to assign it to a group of coyote-like dogs.

The coyote-like canid from Kudaro caves diverges with the recent $C$. latrans in the wider upper premolar P2 (vestibulo-lingual diameter relative greatest length) and comparatively shorter P4, i.e. the Kudaro small canid is characterized by less carnivorous dentition (Baryshnikov, 1986). In addition, this canid has a comparatively long M2, enlarged metacone of M1, and another position of the upper carnassial tooth P4 (see above).

Teeth of the Kudaro small canid morphologically differ from those of fossil coyote-like dogs from North
America. The Pliocene species C. leptophagus and $C$. thooides Tedford et al., 2009 are characterized in more archaic dentition. In addition, the Kudaro canid reveals differences with $C$. lepophagus by such apomorphic characters for Canini as the position of protocone of $\mathrm{P} 4$ not beyond the anterior end of paracone and markedly enlarged paracone of M1 (Tedford et al., 2009). C. edwardii Gazin, 1942 from the Early and Middle Pleistocene was noticeably larger (its minimum length parameters of $\mathrm{P} 4$ and $\mathrm{M} 1$ exceed corresponding measurements of ZIN 31889-1) (see Tedford et al., 2009).

A comparison of the small canid from Kudaro 1 Cave with miniature fossil dogs from Europe shows that the former, by dimensions of the carnassial P4, were smaller than $C$. arnensis from sites in Italy (Poggio Rosso, Tasso, Upper Valdarno, Bucine) and Greece (Gerakarou) (see Brugal \& Boudadi-Maligne, 2011). At the same time, there is considerable morphometric similarity with the fossil species $C$. accitanus and $C$. senezensis from Southern Europe (Martin, 1973; Garrido \& Arribas, 2008).

Brugal \& Boudadi-Maligne (2011) stated that European fossil coyote-like species may represent a single species, $C$. arnensis, and the observed biometric differences between them are explained by sexual and geographic variability. Since ZIN 31889-1 belongs to a 
Table 5. Measurements (in $\mathrm{mm}$ ) of lower premolars in small and medium sizes Canis.

\begin{tabular}{|c|c|c|c|c|c|c|c|c|c|}
\hline \multirow[t]{2}{*}{ Measurements } & \multirow[t]{2}{*}{ Museum number } & \multicolumn{2}{|c|}{ p1 } & \multicolumn{2}{|c|}{ p2 } & \multicolumn{2}{|c|}{ p3 } & \multicolumn{2}{|c|}{$\mathrm{p} 4$} \\
\hline & & $\mathrm{L}$ & $\mathrm{W}$ & $\mathrm{L}$ & $\mathrm{W}$ & $\mathrm{L}$ & $\mathrm{W}$ & $\mathrm{L}$ & $\mathrm{W}$ \\
\hline \multicolumn{10}{|c|}{ C. arnensis kudarensis ssp. nov. } \\
\hline \multirow{4}{*}{ Kudaro 1} & ZIN 36605 & & & & & 9.7 & 4.6 & & \\
\hline & ZIN 36608 & & & & & 10.6 & 4.6 & & \\
\hline & ZIN 36607-1 & & & & & & & 13.2 & 5.8 \\
\hline & ZIN 36604 & & & & & & & - & 5.5 \\
\hline \multicolumn{10}{|c|}{ C. etruscus } \\
\hline $\begin{array}{l}\text { East Runton, Forest Bed, } \\
\text { England }\end{array}$ & NHM 6170 & & & 11.9 & 5.2 & & & & \\
\hline \multicolumn{10}{|c|}{ C. mosbachensis } \\
\hline \multicolumn{10}{|c|}{ Caucasus } \\
\hline \multirow{5}{*}{ Kudaro 1, layer 5} & ZIN 36634 & 5.4 & 3.8 & & & & & & \\
\hline & ZIN 36631 & 6.4 & 4.0 & & & & & & \\
\hline & ZIN 36642 & & & & & 11.8 & 5.1 & & \\
\hline & ZIN 36629 & & & & & & & 14.1 & 6.7 \\
\hline & ZIN 36636 & & & & & & & - & 6.4 \\
\hline Kudaro 1, mixed layers & ZIN 36638-1 & & & & & & & 13.0 & 6.7 \\
\hline \multirow{2}{*}{ Kudaro 3, layer 8} & ZIN 32023-1 & & & 10.2 & 5.0 & & & & \\
\hline & ZIN 32022-1 & & & & & 12.4 & 5.7 & & \\
\hline \multicolumn{10}{|c|}{ Europe } \\
\hline \multirow{5}{*}{ Westbury Quarry Cave, England } & NHM 33640 & & & 10.3 & 3.9 & 11.5 & 4.9 & & \\
\hline & NHM 33937 & & & & & & & 13.0 & 6.4 \\
\hline & NHM 33938 & & & & & & & 15.2 & 6.9 \\
\hline & NHM 47519 & & & 12.2 & 5.0 & & & & \\
\hline & NHM 47520 & & & & & & & 13.5 & 5.9 \\
\hline \multirow{11}{*}{ Stránska skála, Czech Republic } & MMBA 5382-2 & & & 12.0 & 5.2 & 12.6 & 5.1 & 13.7 & 6.2 \\
\hline & MMBA 5382-5 & & & 11.3 & 5.0 & & & & \\
\hline & MMBA 5382-8 & & & & & 12.1 & 4.9 & 13.2 & 6.2 \\
\hline & MMBA 5382-10 & & & & & & & 13.5 & 6.6 \\
\hline & MMBA 5382-13 & & & 10.7 & 4.6 & 11.5 & 4.7 & 12.7 & 5.8 \\
\hline & MMBA 5382-14 & & & 11.2 & 4.4 & 12.2 & 4.7 & & \\
\hline & MMBA 1476 & & & 11.1 & 4.5 & & & 12.9 & 5.5 \\
\hline & MMBA 1571 & & & & & & & 14.7 & 7.0 \\
\hline & MMBA 1821 & & & & & & & 14.8 & 6.6 \\
\hline & MMBA 2097 & & & & & 12.7 & 5.5 & & \\
\hline & MMBA 2394 & & & & & 12.7 & 6.1 & & \\
\hline Kozi-Grzbiet, Poland & ISAK MF/1343 & & & & & & & 14.0 & 5.8 \\
\hline \multicolumn{10}{|c|}{ C. lunellensis } \\
\hline Kudaro 3, layer 6 & ZIN 31884-4 & & & 11.7 & 5.8 & 12.6 & 5.5 & & \\
\hline
\end{tabular}

female, it may be suggested that small size of type specimens of $C$. accitanus and $C$. senezensis also implies they are females; this idea maintains the view by Brugal \& Boudadi-Maligne (2011).

The small coyote-like dog from Kudaro 1 Cave diverges from $C$. arnensis in several derived characters of dental morphology: the M1 paracone markedly enlarged, p3 lies below p2 and p4. It may result from a large time gap dividing these canids $(C$. arnensis from Western Europe is more than 1 million years older than the Kudaro finding).

I consider the small canid from Kudaro caves to be a later representative of $C$. arnensis (sensu Brugal \& Boudadi-Maligne, 2011), surviving in Southern Caucasus until the Middle Pleistocene. Its geographical location, geological age, and characters of dentition pro- vide the basis for a new subspecies, C. arnensis kudarensis Baryshnikov subsp. nov.

Discussion. The examined fossil material indicates for the first time the presence of fossil coyote-like canid in the Middle Pleistocene mammal fauna of the South Caucasus. This material is distributed throughout layer 5 in Kudaro 1 Cave, including the contact with upper layer 4 ("lens X"). Only a single bone has been found in Kudaro 3 Cave within the lowermost sediment (layer 8).

In the Caucasus region, the postcranial remains from layer 5 in Azykh Cave in Azerbaijan, earlier attributed to C. aureus (Gadzhiev \& Aliev, 1966), probably belong to C. arnensis kudarensis. Vereshchagin (1951), examining the species-rich material on carnivores from the asphalt pit of Binagady near Baku, drew attention to the absence of $C$. aureus there and assumed this species 
Table 6. Measurements (in mm) of lower molars in small and medium sizes Canis.

\begin{tabular}{|c|c|c|c|c|c|c|}
\hline \multirow{2}{*}{ Measurements } & \multirow{2}{*}{ Museum number } & \multicolumn{3}{|c|}{$\mathrm{m} 1$} & \multicolumn{2}{|c|}{$\mathrm{m} 2$} \\
\hline & & $\mathrm{L}$ & Ltald & $\mathrm{W}$ & $\mathrm{L}$ & $\mathrm{W}$ \\
\hline \multicolumn{7}{|c|}{ C. arnensis kudarensis ssp. nov. } \\
\hline \multirow{2}{*}{ Kudaro 1, layer 5} & ZIN 36607-4 & & & & 9.0 & 6.8 \\
\hline & ZIN 36614 & & & & 9.2 & 6.9 \\
\hline \multicolumn{7}{|c|}{ C. mosbachensis } \\
\hline \multicolumn{7}{|c|}{ Caucasus } \\
\hline \multirow{6}{*}{ Kudaro 1, layer 5} & ZIN 31888 & 23.9 & 7.5 & 9.2 & & \\
\hline & ZIN 31886 & 23.9 & 7.4 & 9.3 & & \\
\hline & ZIN 36623-1 & & & & 9.8 & 6.9 \\
\hline & ZIN 36618 & & & & 9.7 & 7.4 \\
\hline & ZIN 31887 & & & & 9.9 & 7.6 \\
\hline & ZIN 36641 & & & & 10.9 & 7.8 \\
\hline \multicolumn{7}{|c|}{ Europe } \\
\hline \multirow{6}{*}{ Westbury Quarry Cave, England } & NHM 33640 & 21.8 & 6.1 & 7.8 & & \\
\hline & NHM 33642 & 22.9 & 6.0 & 8.9 & & \\
\hline & NHM 33937 & 22.4 & 6.7 & 9.4 & & \\
\hline & NHM 33938 & 25.4 & 8.3 & 10.2 & & \\
\hline & NHM 47518 & 23.3 & 6.7 & 8.9 & & \\
\hline & NHM $375 / 75$ & 24.0 & 6.9 & 9.7 & & \\
\hline \multirow{16}{*}{ Stránska skála, Czech Republic } & MMBA 5382-3 & & & & 10.1 & 7.1 \\
\hline & MMBA 5382-4 & 23.7 & 6.6 & 9.3 & & \\
\hline & MMBA 5382-12 & & & & 10.4 & 7.7 \\
\hline & MMBA 5382-21 & 22.5 & 6.3 & 8.6 & & \\
\hline & MMBA 1332 & 21.1 & 5.4 & 7.8 & & \\
\hline & MMBA 1342 & 23.1 & 6.4 & 8.8 & & \\
\hline & MMBA 1371 & & & & 10.4 & 7.0 \\
\hline & MMBA 1438 & 23.5 & 6.7 & 9.1 & & \\
\hline & MMBA 1496 & 24.6 & 7.2 & 9.4 & 10.7 & 7.8 \\
\hline & MMBA 1819 & 22.0 & 6.6 & 8.3 & & \\
\hline & MMBA 2098 & & & & 10.9 & 7.5 \\
\hline & MMBA 2101 & 21.8 & 6.8 & 8.3 & & \\
\hline & MMBA 5381 & 23.0 & 6.2 & 8.6 & & \\
\hline & MMBA Sch132 & 21.5 & 6.8 & 8.4 & & \\
\hline & MMBA Fe19 & 22.7 & 6.9 & 9.1 & & \\
\hline & MMBA Fe20 & 22.4 & 6.7 & 8.5 & & \\
\hline \multicolumn{7}{|c|}{ C. lunellensis } \\
\hline Kudaro 3, layer 7 & ZIN 36645 & - & 6.4 & - & & \\
\hline Kudaro 3, layer 6 & ZIN 31884-3 & 24.5 & 6.3 & 9.7 & & \\
\hline
\end{tabular}

to disperse into Caucasus only in Holocene. Yet, no reliable remains of the Pleistocene age were found there. Fossil coyote-like dogs were never recorded in Northern Caucasus.

Fossil coyote-size canids occurred in Europe in the Early Pleistocene (arnensis, senezenensis, accitanus) and their discovery in the Kudaro fauna assigned to the new subspecies (C. arnensis kudarensis subsp. nov.) testify that these small-size canids survive in Eurasia until the middle period of the Middle Pleistocene.

Brugal \& Boudadi-Maligne (2011) pointed out the importance of biometrical data for understanding the Pleistocene history of Canis in Western Europe. Although body size cannot be used to evaluate phylogenetic relationships, it indicates the breadth of the ecological niche of ancient canids, and may be used in taxonomy as well as for paleoecological reconstruc- tions. The size parameters of $C$. arnensis kudarensis sp. nov. resemble those of the recent species $C$. latrans and C. aureus, which indicates that they may have shared the same life style with the Caucasian fossil coyote. $C$. arnensis kudarensis sp. nov. was presumably, a gatherer and lived in small groups. Its food is determined to include small mammals and other vertebrates as well as insects, fruits, and carrion.

The early evolution of the genus Canis is not well known. Many species from the Miocene and Pliocene of the North America and Eurasia, previously included into this genus, are now assigned to the genus Eocyon (Tedford et al., 2009; Sotnikova \& Rook, 2011).

First representatives of the genus Canis (C. ferox Miller et Carranza-Castañeda, 1998) appear in the geological record of the North America in the Late Miocene (late Hemphillian, ca 6.0 Ma) (Tedford et al., 
Table 7. Measurements (in mm) of limb bones of Caucasian fossil Canis.

\begin{tabular}{|c|c|c|c|c|c|c|c|c|}
\hline \multirow[t]{2}{*}{ Bones } & \multirow{2}{*}{$\begin{array}{l}\text { Localities and } \\
\text { museum number }\end{array}$} & \multicolumn{7}{|c|}{ Measurements } \\
\hline & & GL & GB & $\mathrm{Bp}$ & $\mathrm{Dp}$ & SD & $\mathrm{Bd}$ & $\mathrm{Dd}$ \\
\hline \multicolumn{9}{|c|}{ Fore limb } \\
\hline \multicolumn{9}{|c|}{ C. arnensis kudarensis } \\
\hline Humerus & Kudaro 3 (ZIN 36615) & & & & & & 28.6 & \\
\hline Radius & Kudaro 1 (ZIN 36613) & & & 16.4 & 10.2 & & & \\
\hline $\mathrm{Mc} 2$ & Kudaro 1 (ZIN 36606-2) & & & 8.0 & 11.0 & & & \\
\hline \multicolumn{9}{|c|}{ C. mosbachensis } \\
\hline Pisiform & Kudaro 1 (ZIN 31888-2) & 20.9 & 11.5 & & & & & \\
\hline $\mathrm{Mc} 4$ & Kudaro 3(ZIN 32022-3) & & & & & 8.3 & 10.5 & 11.4 \\
\hline \multicolumn{9}{|c|}{ C. lunellensis } \\
\hline Mc3 & Kudaro 3 (ZIN 31884-6) & & & & & & 12.3 & \\
\hline Mc4 & Kudaro 3 (ZIN 36644-1) & & & 8.8 & 14.0 & 8.2 & & \\
\hline \multicolumn{9}{|c|}{ C. lupus } \\
\hline \multirow{5}{*}{ Humerus } & Kudaro 1 (ZIN 36667) & & & & & 17.8 & & \\
\hline & Kudaro 3 (ZIN 36655) & & & & & & 42.6 & \\
\hline & Binagady (ZIN 22384-2) & & & & & & 44.7 & \\
\hline & Binagady (ZIN 22384-4) & & & & & & 39.4 & \\
\hline & Binagady (ZIN 22384-5) & & & & & & 42.1 & \\
\hline Radius & Kudaro 3 (ZIN 36658-6) & & & & & 16.1 & & \\
\hline Mc3 & Kudaro 1 (ZIN 36650-1) & & & 10.9 & 15.5 & & & \\
\hline \multirow{2}{*}{ Mc5 } & Kudaro 1 (ZIN 36648) & & & 14.1 & 14.2 & & & \\
\hline & Kudaro 3 (ZIN 36653) & & & 14.4 & 13.8 & 9.1 & & \\
\hline \multicolumn{9}{|c|}{ Hind limb } \\
\hline \multicolumn{9}{|c|}{ C. arnensis kudarensis } \\
\hline Talus & Kudaro 1 (ZIN 36603-1) & 25.5 & 17.7 & & & & & \\
\hline Calcaneus & Kudaro 1 (ZIN 36606-1) & 40.6 & 15.5 & & & & & \\
\hline Navicular & Kudaro 1 (ZIN 36606-3) & 9.0 & 14.5 & & & & & \\
\hline \multicolumn{9}{|c|}{ C. mosbachensis } \\
\hline Patella & Kudaro 1 (ZIN 36628-1) & 25.1 & 15.5 & & & & & \\
\hline Tibia & Kudaro 1 (ZIN 36632-1) & & & & & & 23.0 & 16.4 \\
\hline $\mathrm{Mt3}$ & Kudaro 1 (ZIN 36635) & & & 11.9 & 17.4 & 9.0 & & \\
\hline Calcaneus & Kudaro 3 (ZIN 32022-2) & - & 21.4 & & & & & \\
\hline $\mathrm{Mt5}$ & Kudaro 1 (ZIN 36620-2) & & & 10.5 & & & & \\
\hline \multicolumn{9}{|c|}{ C. lupus } \\
\hline Talus & Kudaro 3 (ZIN 36658-1) & 33.1 & 24.5 & & & & & \\
\hline Calcaneus & Kudaro 3 (ZIN 36658-2) & 55.4 & 24.1 & & & & & \\
\hline
\end{tabular}

2009). To the end of Pliocene (Early and Late Blancan), this species has been replaced by the coyote-like canid C. lepophagus, which regards as the ancestor of the recent coyote $C$. latrans (Novak, 1979) or as the ancestor of all fossil species from the genus Canis in the North America (Tedford et al., 2009). At the end of Pliocene and during the Pleistocene, a group of small dogs with jackal-like dentition (C. thooides, $C$. feneus Tedford et al., 2009, and C. cedazoensis Mooser et Dalquest, 1975) evolved there. Beginning in the Late Pliocene (late Blancan) and until the Late Pleistocene (Irvingtonian), North America is inhabited by C. edwardii Gazin, 1942 sharing synapomorphies with the coyote $(C$. latrans) and with the golden jackal $(C$. aureus) (Tedford et al., 2009).

In Africa, the earliest find of Canis sp. is dated ca 3.5 Ma (South Turkwel) (Werdelin \& Lewis, 2000). It represents the oldest record of the genus Canis outside North America, testifying to dispersal of this genus from North America across Eurasia as early as the Early Pliocene.

In Eurasia, a Canis-like dog of uncertain taxonomic assessment has been found at Vialette in France, which is dated ca 3.14 Ma (Lacombat et al., 2008). However, reliable finds of Canis, judging from isolated remains of these canids in St. Vallier (Argant, 2004) and Costa di S. Giacomo (Sardella \& Palombo, 2007) are attributed by the end of Pliocene (near 2.2 Ma). In the Early Pleistocene, lepophagus-like canids might have migrated to Eurasia through Beringia and given rise to $C$. arnensis.

The molecular data reveal close relationships between C. latrans, C. aureus and C. lupus (Zravý \& Řičánková, 2004; Bardeleben et al., 2005a), indicating a possible common ancestor of probable Holarctic origin. Phylogenetic analysis, based on the skeletal and dental characters, unites $C$. latrans, $C$. aureus and $C$. mosbachensis into a single clade (Wang et al., 2004; 
Tedford et al., 2009). The Africal jackals (C. mesomelas, C. adustus) are regarded, on the basis of molecular genetic studies, to be a sister taxon to other species of Canis (Bardeleben et al., 2005b) or to other Canis + Cuon/Lycaon (Zravý \& Řičánková, 2004).

†Canis arnensis kudarensis Baryshnikov subsp. nov.

Etymology. The name is derived from the Kudaro caves.

Holotype. Maxilla ZIN 31889-1, Kudaro 1 Cave, layer 5; collector V.P. Lioubine, 1959 (Fig. 1A). Holotype measurements are given in Tab. 1.

Diagnosis. Small coyote-like canid, resembling in the size of cheek teeth $C$. arnensis from the Early Pleistocene of Mediterranean Europe, but differing from it by derivative characters of the tooth morphology: the M1 paracone is markedly enlarged, p3 lying below p2 and $\mathrm{p} 4$.

Distribution. Middle Pleistocene of Southern Caucasus (Kudaro caves).

\section{$\uparrow$ Canis mosbachensis Soergel, 1928}

Referred specimens. Middle Pleistocene, Kudaro 1 Cave: left maxilla with P4-M2 (ZIN 36621, layer 5, horizon 5, 1957); left upper canine (ZIN 36624, layer 5, horizon 8, 1958); left P1 (ZIN 36640, layer 5c, horizon 2, 1984); right P3 (ZIN 36626, layer 5, horizon 8, 1958); left mandible with p2, p4 and m1 (ZIN 36643, layer 5f, horizon 1, 1987); right mandible fragment with m1 (ZIN 31888-1, layer 5, lens R, 1980); right mandible fragment with $\mathrm{m} 2$ (ZIN 36623-1, layer 5, horizon 5, 1958); left lower canine (ZIN 36625, layer 5, horizon 8, 1958); tree right lower canines (ZIN 36619, layer 5, horizon 4, 1957; 36620-1, layer 5, horizon 4, 1957; 36630-1, layer 5, horizon 3, 1959); left p1 (ZIN 36631, layer 5, horizon 3, 1959); right p1 (ZIN 36634, layer 5, horizon 3, 1961); left p3 (ZIN 36642, layer 5f, horizon 1-2, 1987); two right p4 (ZIN 36629, layer 5, horizon 2, 1959; 36638-1, mixed layers, 1980); fragment of right p4 (ZIN 36636, layer 5, horizon 9, 1961); left m1 (ZIN 31886, layer 5, horizon 8); fragment of left m1 (ZIN 36628-3, layer 5, horizon 1, 1959); two left $\mathrm{m} 2$ (ZIN 36641, layer 5c, horizon 4, 1986; 31887, layer 5c, horizon 4, 1980); right $\mathrm{m} 2$ (ZIN 36618, layer 5, horizon 2, 1957); right pisiform bone (ZIN 31888-2, layer 5, lens R, 1980); right patella (ZIN 36628-1, layer 5, horizon 1, 1959); left tibia (ZIN 36632-1, layer 5, horizon 5, 1959); proximal fragment of right Mt3 (ZIN 36635 , layer 5, horizon 6,1961 ); right cuneiform (ZIN 36639, layer 5c, horizon 2, 1984). Kudaro 3 Cave: left mandible fragment with p2 (ZIN 32023-1, layer 8a, 1981); right mandible fragment with p3 (ZIN 32022-1, layer 8, 1981); left lower canine (ZIN 32023-2, layer 8a, 1981); fragment of right Mc4 (ZIN 32022-3, layer 8, 1981); left calcaneus (ZIN 32022-2, layer 8, 1981); fragment of left Mt5 (ZIN 36620-2, layer 5, horizon 4, 1957). There are also vertebrae, phalanges and bone fragments; total 110 bones.

Description. Fossil remains of a small wolf from layer 5 in Kudaro 1 Cave have been previously assigned to Canis cf. etruscus (Baryshnikov, 1986), following the wide interpretation of the species C. etruscus Forsyth Major, 1877, owing to the fact that it comprises all European medium-size forms of Canis from Late Pliocene to Middle Pleistocene (Bonifay, 1971). It was subsequently pointed out that, regarding the smaller wolf from the Early and Middle Pleistocene as a separate species $C$. mosbachensis, the Kudaro material should be considered to belong to this species (Baryshnikov, 1986: 38).

The left maxilla ZIN 36621 (Fig. 1B) exhibits the length of the upper carnassial tooth P4 (22.2 mm) exceeding the length of this tooth in $C$. mosbachensis from the sample from Stránska skála in the Czech Republic (19.8-21.0 mm, n=5) (Tab. 8), but, nevertheless, falling into the value limits for this parameter in

Table 8. Measurements (in mm) of maxilla in Canis mosbachensis and C. etruscus.

\begin{tabular}{|c|c|c|c|c|}
\hline \multirow{3}{*}{ Measurements } & \multicolumn{3}{|c|}{ C. mosbachensis } & \multirow{2}{*}{$\begin{array}{c}\text { C. etruscus } \\
\text { Olivola, Italy }\end{array}$} \\
\hline & $\begin{array}{c}\text { Kudaro } 1 \text { Cave, } \\
\text { layer } 5\end{array}$ & $\begin{array}{l}\text { Stránska skála, } \\
\text { Czech Republic }\end{array}$ & $\begin{array}{c}\text { Westbury Quarry Cave, } \\
\text { England }\end{array}$ & \\
\hline & ZIN 36621 & MMBA 1532 & NHM 47669 & MNHN 1891-11 \\
\hline Length P1-M1 & & & 68.6 & \\
\hline Length P1-P4 & & & 56.5 & \\
\hline Length P4-M1 & 34.2 & & & \\
\hline \multicolumn{5}{|c|}{ Teeth } \\
\hline P2 L & & & 11.9 & \\
\hline $\mathrm{W}$ & & & 5.0 & \\
\hline P4 L & 22.2 & 19.9 & 22.4 & 19.8 \\
\hline Lpa & 14.6 & 13.0 & & 12.4 \\
\hline W & 10.8 & 10.0 & 10.3 & 10.0 \\
\hline M1 L & 13.6 & 13.2 & 14.4 & 14.4 \\
\hline Lpa & 7.5 & & 8.2 & 7.7 \\
\hline $\mathrm{W}$ & 16.3 & 16.4 & 16.8 & 16.4 \\
\hline M2 L & & & & 7.5 \\
\hline $\mathrm{W}$ & & & & 10.4 \\
\hline
\end{tabular}




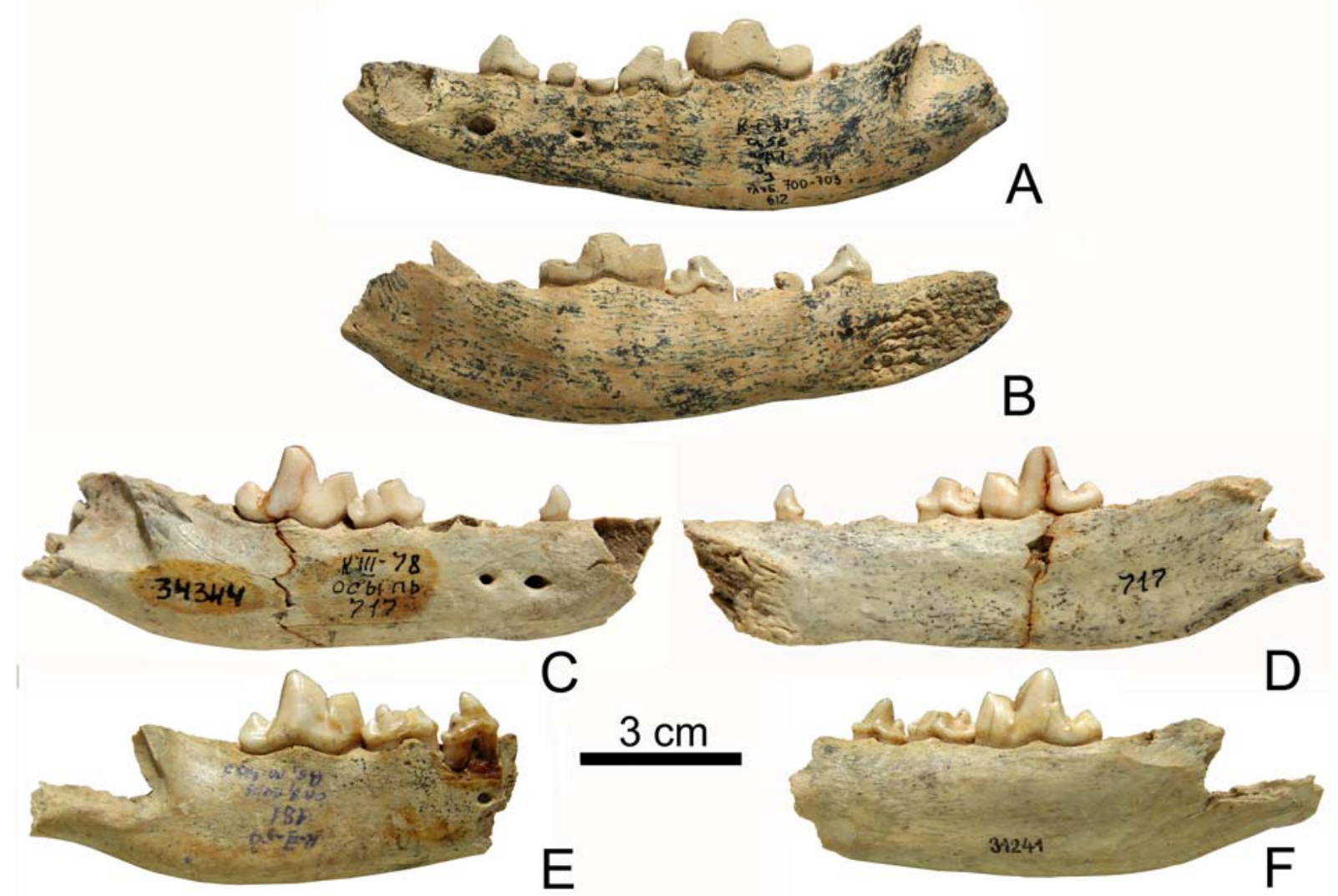

Figure 5. Mandibles of Canis mosbachensis from Kudaro 1 (A, B) and Cuon alpinus caucasicus from Kudaro 3 (C-F); labial (A, C, E) and lingual (B, D, F) views.

A, B - ZIN 36643; C, D - ZIN 34344; E, F - ZIN 31241, holotype.

the sample from Untermaßfeld in Germany (20.4-23.0 mm, $n=9$; Sotnikova, 2001). The length and width of the molar M1 lie in the range of minimum values for these measurements in C. mosbachensis, in the sample from l'Escale in France (Bonifay, 1971).

The upper canine from Kudaro 1 Cave (ZIN 36624) resembles in its shape that of C. lupus, being, however, slightly smaller in the size (Tab. 2). Its length and width are placed within the limits of these measurements in the samples from Untermaßfeld.

$\mathrm{P} 1$ is single-cusped. The tooth $\mathrm{P} 3$ has the posterior cusp markedly developed. The upper carnasial tooth P4 with small protocone, which is situated approximately at the level of the anterior wall of paracone; there is a distinct concavity between anterior margins of both cusps. There is a weak labial cingulum, showing, however, better development in comparison with that in $C$. lupus. Paracone of M1 is markedly enlarged relatively to metacone. Protocunule is present. Protocone is noticeably higher than metaconule. Hypocone is high and non-divided. The upper margin of the tooth crown bears cingulum, which runs as far as the hypocone and merges with it. The labial cingulum is well-developed and complete.
The length of c1-m3 in the mandible ZIN 36643 (Fig. 5A, B; Tab. 9) from layer 5 in Kudaro 1 Cave does not exceed limits of variation of this length in C. mosbachensis from Untermaßfeld in Germany (Sotnikova, 2001). The mandible fragment ZIN 31888-1 (Fig. 3A, B) from layer 5 (lens R) in Kudaro 1 Cave has a similar alveolar length of $\mathrm{p} 3-\mathrm{m} 1(48.5 \mathrm{~mm})$ and ramus height in front of $\mathrm{ml}(21.3 \mathrm{~mm})$ to specimens of C. mosbachensis from Voigstedt in Germany (Thenius, 1965).

The shape and dimensions of lower premolars p1p4 from the Kudaro collection are the same as those in C. mosbachensis (Tab. 5). The premolar $\mathrm{p} 2$ is missing a posterior cusp (Fig. 3K); this cusp is small in p3 and well-developed in p4 (Fig. 3L).

Earlier two specimens of the lower carnassial tooth m1 from Kudaro 1 Cave (ZIN 31886 and 31888-1; Fig. $3 \mathrm{~A}-\mathrm{D})$ have been provisionally assigned to $C$. arnensis, since these specimens occupy an intermediate position by their size between the samples of $C$. arnensis and C. mosbachensis (Baryshnikov \& Tsoukala, 2010). However, the present study reveals that the lower carnassial tooth $\mathrm{m} 1$ from layer 5 in Kudaro 1 Cave corresponds in its dimensions to those of C. mosbachensis from Mosbach in Germany, Stránska skála in Czech 
Table 9. Measurements (in mm) of mandibles in Canis mosbachensis.

\begin{tabular}{|c|c|c|c|c|c|c|}
\hline \multirow{2}{*}{ Measurements } & \multirow{2}{*}{$\begin{array}{c}\begin{array}{c}\text { Kudaro 1 Cave, } \\
\text { layer 5e }\end{array} \\
\text { ZIN } \\
36643\end{array}$} & \multirow{2}{*}{$\begin{array}{c}\text { Westbury } \\
\text { Quarry Cave, } \\
\text { England } \\
\text { NHM } \\
33940\end{array}$} & \multirow{2}{*}{$\begin{array}{c}\text { Perrier, } \\
\text { France } \\
\begin{array}{c}\mathrm{MNHN} \\
\mathrm{n} / \mathrm{n}\end{array}\end{array}$} & \multirow{2}{*}{$\begin{array}{c}\text { Stránska } \\
\text { skála, Czech } \\
\text { Republic } \\
\text { MMBA } \\
1477\end{array}$} & \multicolumn{2}{|c|}{ Mosbach, Germany } \\
\hline & & & & & $\begin{array}{c}\text { NMM } \\
1910 / 411 \\
\end{array}$ & $\begin{array}{c}\text { NMM } \\
1910 / 113 \\
\end{array}$ \\
\hline Length $\mathrm{c} 1-\mathrm{m} 3$ & ca.98.7 & & 90.0 & & & \\
\hline Length $\mathrm{p} 1-\mathrm{m} 3$ & & & & & 87.1 & \\
\hline Length p2-m2 & ca.72.9 & 76.5 & & & & \\
\hline Length $\mathrm{p} 3-\mathrm{m} 2$ & ca.60.3 & & & & & \\
\hline Length $\mathrm{p} 2-\mathrm{p} 4$ & 39.9 & & & & & 41.2 \\
\hline Length $\mathrm{m} 1-\mathrm{m} 3$ & ca.40.9 & 40.9 & 38.7 & & 39.7 & 38.1 \\
\hline Height before $\mathrm{m} 2$ & 23.8 & 27.9 & 21.0 & & 24.6 & 24.8 \\
\hline Height before p3 & 19.5 & 20.9 & & & & \\
\hline \multicolumn{7}{|c|}{ Teeth } \\
\hline p1 L & & & & & 5.4 & \\
\hline $\mathrm{W}$ & & & & & 4.1 & \\
\hline p2 L & 11.3 & 12.1 & 11.0 & 10.9 & 11.7 & 11.7 \\
\hline $\mathrm{W}$ & 4.8 & 5.6 & 4.9 & 4.7 & 5.2 & 5.7 \\
\hline p3 L & 13.0 & 13.3 & 12.3 & 12.3 & 13.9 & 12.7 \\
\hline W & - & 5.8 & 5.1 & 5.1 & 6.4 & 6.0 \\
\hline p4 L & 14.0 & 14.8 & 13.9 & 14.1 & & 14.7 \\
\hline $\mathrm{W}$ & 6.2 & 7.1 & 6.1 & 6.5 & & 6.9 \\
\hline $\mathrm{m} 1 \mathrm{~L}$ & 23.9 & 25.3 & 23.4 & 23.3 & 24.9 & 23.8 \\
\hline Lpad & 8.6 & - & 7.4 & - & - & - \\
\hline Ltald & 6.8 & 8.5 & 7.2 & 6.4 & 6.9 & 6.8 \\
\hline $\mathrm{W}$ & 9.5 & 10.9 & 8.5 & 8.2 & 9.8 & 9.2 \\
\hline $\mathrm{m} 2 \mathrm{~L}$ & & 10.5 & 10.0 & 9.4 & 10.5 & 9.8 \\
\hline $\mathrm{W}$ & & 8.3 & 7.3 & 6.7 & 7.7 & 6.8 \\
\hline $\mathrm{m} 3 \mathrm{~L}$ & & & & & & 4.5 \\
\hline $\mathrm{W}$ & & & & & & 4.5 \\
\hline
\end{tabular}

Republic and from Westbury Quarry in England (Tab. 6). The paraconid blade is turned inwards by a smaller angle than in the recent $C$. lupus from Caucasus and in C. lupus from the Late Pleistocene locality of Binagady in Azerbaijan. The anterior part of the tooth crown is distinctly sloped; as a result, its labial wall forms an angle. Both aforementioned characters were regarded by Thenius (1954) as characteristic of C. mosbachensis; however, those were found to be variable. The protoconid steeply descends to the talonid, anterior and posterior ridges of the former apically meet one another at a sharper angle compared to that in recent $C$. lupus. The protostylid is developed. The metaconid is robust; in the superior view, it oversteps the bounds of the crown contours. Within the sample taken from the Upper Pleistocene (Mousterian) layers in the Kudaro caves and in Binagady, the metaconid is less robust and does not exceed the limits of tooth-crown contours. The talonid is comparatively longer than that in the tooth of the recent Caucasian C. lupus. The talonid basin is deep and more closed from the lingual side in contrast to $C$. lupus. The hypoconid is higher than the entoconid and slightly shifted forwards, its outer wall is steep. There is a tiny entoconulid. The small hypoconulid shelf bears a short well-developed transverse ridge (postcristid) con- necting hypoconid and entoconid. There is a weakly developed cingulid at the hypoconid base, which extends beyond the posterior margin of the talonid.

The lower molar $\mathrm{m} 2$ is slightly shorter than that of C. mosbachensis from European localities (Tab. 6). The protoconid is larger and taller than the metaconid, with the only exception for the specimen (ZIN 36641) with the metaconid exceeding the protoconid in height. The talonid exhibits a basin and a distinct hypoconid. The labial cingulid is well developed, especially in the anterolabial part of the crown, where it is more pronounced than in the recent $C$. lupus from Caucasus.

Bones of the postcranial skeleton are few and fragmentary. Their dimensions are smaller compared to those of the same bones in C. lupus from the Late Pleistocene layers in Kudaro caves and resemble postcranial bone parameters of C. mosbachensis from Untermaßfeld (Sotnikova, 2001). In the fragment of the second cervical vertebra (axis) (ZIN 36734), the breadth at the cranial articulatory surface constitutes $34.6 \mathrm{~mm}$.

By its size and dental morphology, the small wolf from the Middle Pleistocene fauna of Kudaro caves may be assigned to $C$. mosbachensis. Tooth measurements fall into the limits of their variation for the samples of this species from these European localities: 
Westbury Quarry in England, l'Escal in France, Untermaßfeld, Süßenborn and Voigstedt in Germany, Hundsheim in Austria, and Stránská Skála in Czech Republic (Soergel, 1928; Thenius, 1954, 1965; Schaefer, 1969; Bonifay, 1971; Musil, 1972; Bishop, 1982; Sotnikova, 2001). At the same time, the length of the lower carnassial tooth $\mathrm{m} 1$ from Kudaro caves is smaller than that in C. etruscus from the localities of Olivola and Upper Valdarno in Italy (Tab. 10) and Ozernoe in Ukraine (De1 Campana, 1913; Torre, 1967; Baryshnikov, 1986).

Discussion. Bone remains of $C$. mosbachensis are recorded only in the lowermost levels of both Kudaro caves: in layer 5 of Kudaro 1 Cave and in layers 8-8a of Kudaro 3 Cave. These findings testify the presence of this species in Southern Caucasus in the middle part of Middle Pleistocene, i.e. its survival there longer than in Western Europe.

The Mosbach small wolf was, presumably, a less specialized predator in comparison with $C$. lupus. It was capable of hunting smaller ungulates and hares, rodents, and birds and consuming carrion, fruits, and other vegetable food.

In the Southern Caucasus, C. mosbachensis appears to include the small wolf from the Early Pleistocene locality Akalkalaki in Georgia, whose remains were described as the new species C. tengesii (Vekua, 1962). The length of $\mathrm{m} 1$ teeth $(22.2$ and $23.0 \mathrm{~mm})$ of this species corresponds to that of $C$. mosbachensis. In the Northern Caucasus, C. mosbachensis has been identified in the Middle Pleistocene locality of Treugolnaya Cave, on the basis of two specimens of $\mathrm{m} 1$ measuring 21.9 and $23.0 \mathrm{~mm}$ (Baryshnikov, 1994).

Several researchers assign medium-size wolves from the Early and Middle Pleistocene of Europe to a single species C. etruscus (Bonifay, 1971; Pons Moya, 1987; Brugal \& Boudadi-Maligne, 2011). Other authors regard the Middle Pleistocene wolf as a separate species C. mosbachensis (Musil, 1972; Sotnikova, 2001; Tedford et al., 2009) or subspecies C. lupus mosbachensis (Thenius, 1954; Kurtén, 1969; Kurtén \& Poulianos, 1977). Brugal \& Boudadi-Maligne (2011) point out that $C$. etruscus mosbachensis differs from C. lupus in the ratio of the length of the trenchant portion of the lower tooth row (premolars $\mathrm{p} 1-\mathrm{p} 4+\mathrm{m} 1$ trigonid) to the length of its crushing portion ( $\mathrm{m} 1$ talonid + molars $\mathrm{m} 2$ m1). Sotnikova (2001) notes C. mosbachensis has a more derived lower carnassial tooth $\mathrm{m} 1$ compared to the carnassial tooth of $C$. etruscus and, in contrast to $C$. lupus, shows a trend to the complication of cusps on the talonid of $\mathrm{m} 1$. The latter peculiarity is clearly traced in the material from Kudaro 1 Cave.

Tedford et al. (2009), in their phylogenetic analysis, link C. mosbachensis to the species $C$. variabilis Pei, 1934 from China (Zhoukoudian locality 1) and to C. palmidens Teilhard de Chardin et Piveteaua, 1930 from China (Sangkanhe near Nihowan), considering these species as a sister group to the clade C. aureus/ latrans, which is derived by these authors from $C$. edwardii.

\section{$†$ Canis lunellensis Bonifay, 1971}

Referred specimens. Middle Pleistocene, Kudaro 3 Cave: left maxilla with isolated P3, P4 and M1-2 (ZIN 31885-2, 3, 4, layer 7, 1981); left maxilla with P2-M2 (ZIN 31884-1, layer 6, 1980); right maxilla with P4-M2 (ZIN 31885-1, layer 7, 1981); left P1 (ZIN 36646, layer 5, horizon 2, 1974); left P3 (ZIN 36647, layer 5, 1978); right P3 (ZIN 31884-5, layer 6, 1980); left mandible with p2-m2 (ZIN 31884-2, layer 6, 1980); right mandible with p2 and p3 (ZIN 31884-2, layer 6, 1980); fragment of right $\mathrm{m} 1$ (ZIN 36645, layer 7, 1980); right $\mathrm{m} 1$ (ZIN 31884-3, layer 6, 1980); distal fragment of right Mc3 (ZIN 31884-6, layer 6, 1980); proximal fragment of left Mc4 (ZIN 36644-1, layer 6, 1980); in total, 15 fossil fragments were examined.

Description. Earlier the fossil remains of the small wolf from layers 6-7 of the Kudaro 3 Cave were assigned to C. lupus ssp. of the same evolutionary stage as C. lupus lunellensis from Lunel-Viel (Baryshnikov, 1986). This taxon is sometimes considered to have a species rank C. lunellensis (Palombo \& Valli, 2004), which is used in the present study.

The maxillary fragments (ZIN 31884, 31885-2) from layers 6 and 7 in Kudaro 3 Cave have P4 and M1 longer compared to those in ZIN 36621 (C. mosbachensis) (Tab. 11), which corresponds to measurements of these teeth in C. lunellensis from Lunel-Viel (Bonifay, 1971). The upper carnassial teeth P4 within the Kudaro maxillas are nearly equal in length with the molar row M1M2 (97.4-100.9\%, n=3); at the same time, the specimens of P4 from Lunel-Viel virtually are always longer than the molar row. In the recent $C$. lupus from Caucasus, P4 is approximately equal in length with M1-M2 (92.2-109.4\%, n=39) (Baryshnikov, 1986)

Major axes of $\mathrm{P} 3$ and $\mathrm{P} 4$ coincide. $\mathrm{P} 2$ is worn, and it is hard to ascertain the level of development of its posterior cusp. The tooth P3 exhibits this cusp markedly developed. The upper carnassial tooth $\mathrm{P} 4$ resembles in its shape the corresponding tooth of C. lupus. Its protocone is situated at the level of the anterior margin of the tooth crown. This cusp may be large (ZIN 318851; Fig. 6B) or non-developed (ZIN 31884-1; Fig. 6A). The depression between anterior margins of the paraconid and protoconid is shallow. M1 has a large inner portion and well developed complete anterolingual cingulum (in C. lupus it is less marked and interrupted). There is a distinctive parastyle. The paraconule is present. The hypocone is high and may be occasionally divided. The labial cingulum is well developed and complete.

The mandible ZIN 31884-2 from layer 6 of Kudaro 3 Cave falls, by the length of the lower carnassial tooth $\mathrm{m} 1$ (Tab. 10), into the area of minimum length values for this tooth in C. lunellensis from Lunel-Viel and corresponds in alveolar length of $\mathrm{m} 1-\mathrm{m} 3$ to specimens of $C$. mosbachensis from Untermaßfeld (Sotnikova, 2001).

The lower premolar $\mathrm{p} 2$ is characterized by a posterior cusp and p3 has two posterior cusplets. The lower 
Table 10. Measurements (in mm) of mandibles in Canis etruscus and C. lunellensis.

\begin{tabular}{|c|c|c|c|}
\hline \multirow{3}{*}{ Measurements } & \multicolumn{2}{|c|}{ C. etruscus } & \multirow{3}{*}{$\begin{array}{c}\text { C. lunellensis } \\
\text { Kudaro } 3 \text { Cave, layer } 6 \\
\text { ZIN } 31884-2\end{array}$} \\
\hline & Ponte Molle, Italy & Olivola, Italy & \\
\hline & IGPR n/n & MNHN 1891-11 & \\
\hline \multicolumn{4}{|l|}{ Length $\mathrm{c} 1-\mathrm{m} 3$} \\
\hline \multicolumn{4}{|l|}{ Length $\mathrm{p} 2-\mathrm{m} 2$} \\
\hline Length $\mathrm{p} 3-\mathrm{m} 2$ & & & 61.4 \\
\hline \multicolumn{4}{|l|}{ Length p2-p4 } \\
\hline Length $\mathrm{m} 1-\mathrm{m} 3$ & 41.0 & ca39.0 & 39.3 \\
\hline Height before $\mathrm{m} 2$ & 27.4 & 24.5 & \\
\hline Height before p3 & 22.0 & & \\
\hline \multicolumn{4}{|c|}{ Teeth } \\
\hline p2 L & 11.2 & & \\
\hline $\mathrm{W}$ & 5.5 & & \\
\hline p3 L & & & 12.8 \\
\hline $\mathrm{W}$ & & & 6.0 \\
\hline p4 L & & & 14.9 \\
\hline $\mathrm{W}$ & & & 7.6 \\
\hline $\mathrm{m} 1 \mathrm{~L}$ & 25.6 & 23.6 & 24.1 \\
\hline Lpad & 8.7 & 7.3 & 8.0 \\
\hline Ltald & 7.4 & 7.3 & 5.7 \\
\hline W & 10.0 & 9.7 & 9.4 \\
\hline $\mathrm{m} 2 \mathrm{~L}$ & 10.9 & 10.2 & 10.9 \\
\hline $\mathrm{W}$ & 7.5 & 7.6 & 7.4 \\
\hline
\end{tabular}

Table 11. Measurements (in mm) of maxilla in Canis lunellensis and C. chihliensis.

\begin{tabular}{|c|c|c|c|c|}
\hline \multirow{3}{*}{ Measurements } & \multicolumn{3}{|c|}{ C. lunellensis } & \multirow{2}{*}{$\begin{array}{c}\text { C. chihliensis } \\
\text { Locality } 64, \text { Fengwo near } \\
\text { Huanglu, China }\end{array}$} \\
\hline & $\begin{array}{c}\text { Kudaro } 3 \text { Cave, } \\
\text { layer } 7 \\
\end{array}$ & $\begin{array}{c}\text { Kudaro } 3 \text { Cave, } \\
\text { layer } 7 \\
\end{array}$ & $\begin{array}{c}\text { Kudaro } 3 \text { Cave, } \\
\text { layer } 6 \\
\end{array}$ & \\
\hline & ZIN 31885-1 & ZIN 31885-2,3 & ZIN 31884-1 & MEU 3496, holotype \\
\hline Length P1-M2 & & & 81.7 & \\
\hline Length P4-M2 & 43.0 & & 42.7 & 46.0 \\
\hline Length P4-M1 & 36.3 & & 35.3 & \\
\hline Length M1-M2 & 24.0 & 24.1 & 23.3 & \\
\hline \multicolumn{5}{|c|}{ Teeth } \\
\hline $\mathrm{P} 2 \mathrm{~L}$ & & & 12.0 & \\
\hline $\mathrm{W}$ & & & 5.3 & \\
\hline P3 L & & 14.4 & 13.8 & 14.0 \\
\hline $\mathrm{W}$ & & 6.1 & 5.7 & 6.3 \\
\hline P4 L & 23.0 & 22.9 & 23.0 & 23.9 \\
\hline Lpa & 15.9 & 15.4 & 14.9 & 15.3 \\
\hline W & 13.2 & 12.45 & 11.5 & 13.3 \\
\hline M1 L & 15.0 & 14.6 & 14.3 & 16.6 \\
\hline Lpa & 7.9 & 7.9 & 7.7 & 8.8 \\
\hline W & 20.2 & 19.5 & 18.2 & 19.2 \\
\hline M2 L & 8.2 & 8.9 & 8.7 & 9.3 \\
\hline $\mathrm{W}$ & 12.9 & 13.35 & 12.2 & 13.0 \\
\hline
\end{tabular}

carnassial tooth $\mathrm{m} 1$ is morphologically similar to that of the recent $C$. lupus. The talonid of ZIN 31884-2, 31884-3 and 36645 (Fig. 3E, H) is more shortened with regard to the tooth greatest length than in $C$. mosbachensis. Both specimens show worn talonid; however, it may be hypothesized that it had no entoconulid and possessed shallow talonid basin. No clear postcristid on the hipoconulid shelf is observed. In C. lunellensis from Lunel-Viel, the entoconulid is also absent (Bonifay, 1971).
Tooth measurements of $C$. lunellensis from Kudaro 3 Cave conform to their minimum values in recent $C$. lupus from Caucasus. The length of P4 in the latter species varies from 22.8 to $29.0 \mathrm{~mm}(n=39)$, the length of $\mathrm{m} 1$ is measured $24.2-31.0 \mathrm{~mm}(n=40)$. In $C$. lunellensis from Lunel-Viel, these dimensions constitute 21.7-24.8 mm ( $n=14)$ for P4 and 23.8-27.4 mm $(n=12)$ for $\mathrm{m} 1$ (Bonifay, 1971). Thus, $C$. lunellensis and $C$. lupus are similar in length of the carnassial teeth, differing, however, in their proportions. 


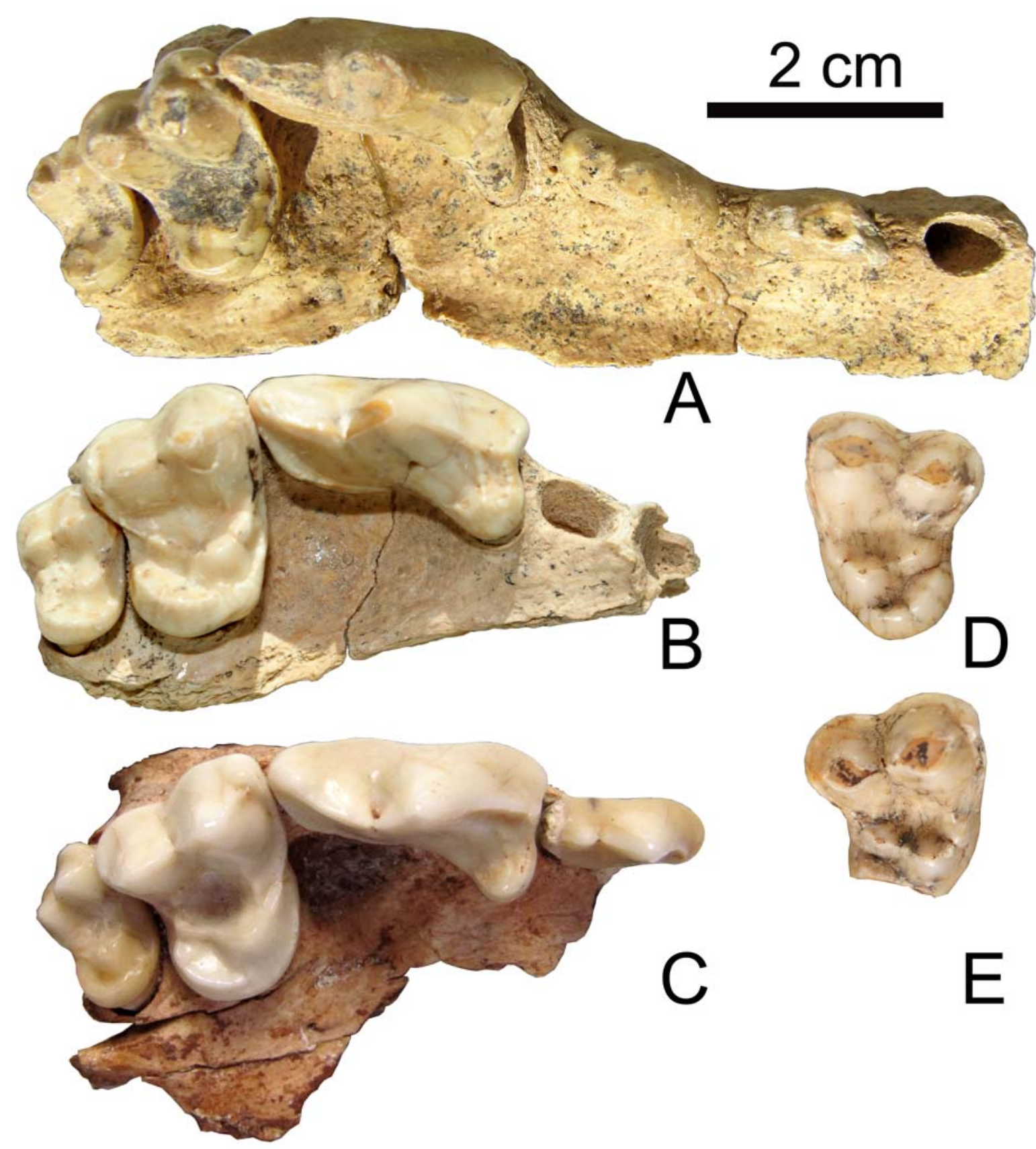

Figure 6. Maxilla fragments (A-C) and upper molar M1 (D, E) of Canis lunellensis (A, B) and C. lupus (D, E) from Kudaro 3 Cave, and C. chihliensis (C); occlusal view.

A — ZIN 31884-1; B - ZIN 31885-1; C — MEU 3496, holotype; D - ZIN 31882-2; E - ZIN 31882-1.

Discriminant Analisys was performed on the basis of three measurements of $\mathrm{m} 1$ (L, Ltald, W) for 6 samples of C. mosbachensis, C. lunellensis, and C. lupus. In the resulting scatterplot of canonical scores, the teeth of C. mosbachensis from Kudaro caves are grouped together with the teeth of this species from European localities (Fig. 7). These are well separated from teeth of $C$. lupus by Root 1 (measurements L, W; $95.4 \%$ of dispersion), i.e. by the total size. The sample of $C$. lunellensis from layers 6-7 of Kudaro 3 Cave locates near $C$. mosbachensis and does not exceed the bounds of variation of recent Caucasian C. lupus.

C. lunellensis from Kudaro 3 Cave resembles in size and morphology the upper cheek teeth of $C$. chihliensis Zdansky, 1924 from the Early Pleistocene of China (Tab. 11; Fig. 6C). Both species are characterized, in particular, by a pronounced development of the anterolingual cingulum in M1. 


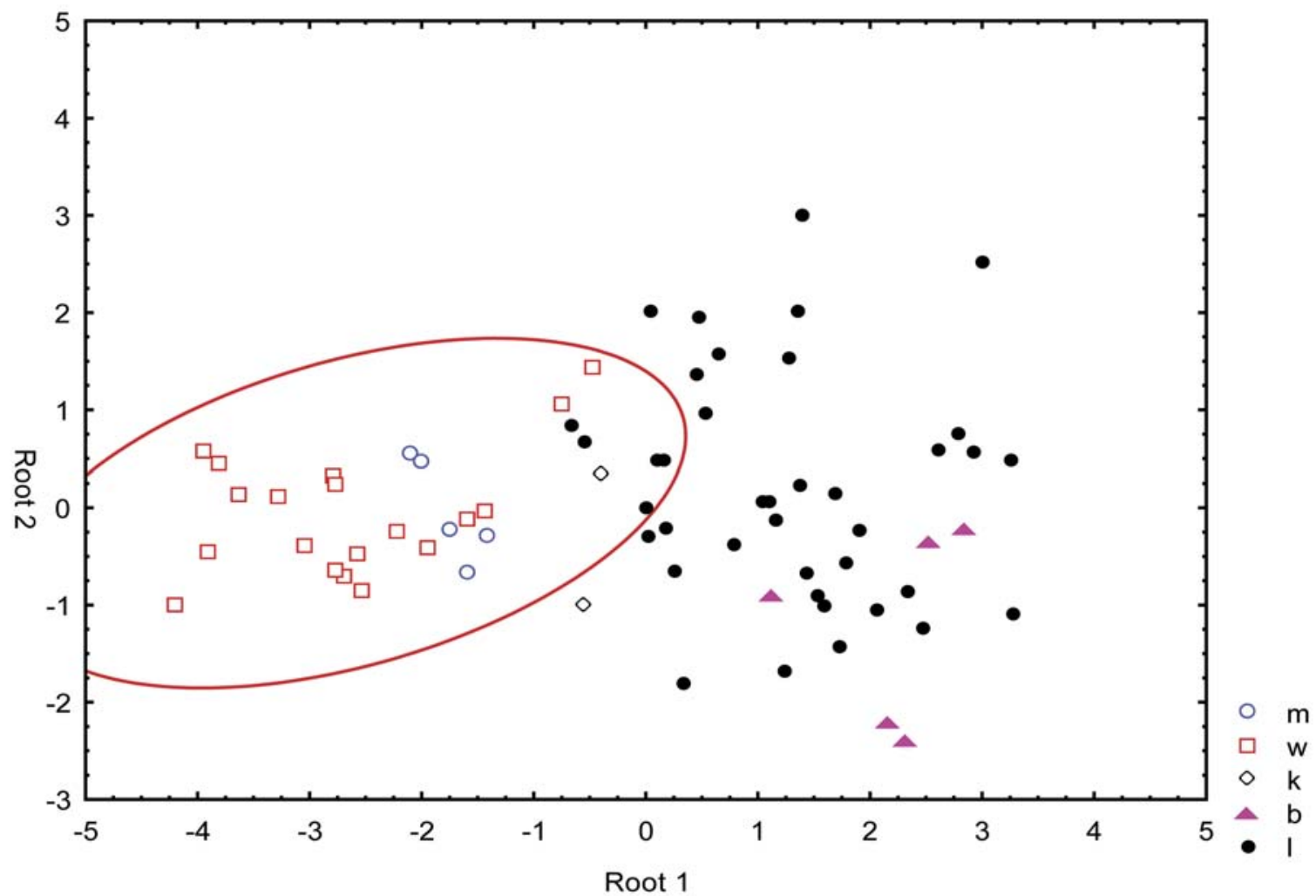

Figure 7. Scatterplot of canonical scores of Root 1 and Root 2 from discriminant analysis of lower carnassial tooth $\mathrm{m} 1$ in Canis. C. mosbachensis: $\mathrm{m}$ - Kudaro 1, layer 5, w - Westbury Quarry and Stránska skála; C. lunellensis: $\mathrm{k}$ - Kudaro 3, layer 6-7; C. lupus: $\mathrm{b}$ - Binagady, 1 - Caucasus, recent.

Discussion. Bones of a small wolf from the Middle Pleistocene layers 5-7 in Kudaro 3 Cave are assigned to $C$. lunellensis. This species, therefore, occurred in Caucasus until nearly the end of the Middle Pleistocene (Saalian, OIS 7, near 0.20-0.25 Ma; Baryshnikov, 2002).

Presumably, a considerable portion of large carnivore tooth-marks found on the bones from the lower layers of Kudaro 3 Cave was created by C. lunellensis. One bone (calcaneus ZIN 31885-5 from the layer 7 of the Kudaro 3 Cave) of $C$. lunellensis has the pathological enlargement of proximal end.

The small wolf $C$. lunellensis has been described from the Lunel-Viel collection as a subspecies C. lupus lunellensis (Bonifay, 1971). Later, new material was found resembling this subspecies in measurements and geological age (Rameaux, Coudoulous I, Balaruc VII and La Fage localities) (Argant, 2009; Brugal \& Boudadi-Maligne, 2011). Some researchers believe this small wolf should be treated as a separate species C.lunellensis, confined to the biochon MNQ23a-MNQ23b, i.e. to the middle and late Galerian, approximately 0.6-0.4 $\mathrm{Ma}$ (Palombo \& Valli, 2004). The discoveries from the Kudaro caves are consequently the youngest for this taxon.

Most researchers include $C$. lunellensis, as a subspecies, in C. lupus (Tedford et al., 2009; Brugal \& Boudadi-Maligne, 2011). C. chihliensis, which is described from Locality 64 in China (Zdansky, 1924), has been also compared with to $C$. lupus (Tedford et al., 2009). Hence, both taxa may be regarded as ancestral to C. lupus.

\section{Canis lupus Linnaeus, 1758}

Referred specimens. Late Pleistocene, Kudaro 1 Cave: right C1 (ZIN 36649-1, layer 4, 1958); left p3 (ZIN 36649-2, layer 4, 1958); right Mc3 (ZIN 36650-1, layer X-4, horizon 1, 1978); left Mc5 (ZIN 36648, layer 3b-c, 1957). Kudaro 3 Cave: skull fragment with incisor alveolar sockets (ZIN 36684-5, layers 3-4, 1975); right maxilla with P3-M1 (ZIN 31880, layer 3, horizon 2, 1959); two left C1 (ZIN 36657-1, layer 4f, 1978; 36654, layer 3b, horizon 2, 1977); left M1 (ZIN 318822, layer 4, horizon 5, 1975), right M2 (ZIN 31882-1, layer 4, horizon 5, 1975), right M2 (ZIN 31883-3, layer 4f, 1980); left mandible fragment with p3-m1 (ZIN 31883-1, 2, layer 4f, 1980); two left c1 (ZIN 36651, layer 4 , horizon 3,$1959 ; 36652$, layer 4 , horizon 6 , 1975); right $\mathrm{m} 1$ (ZIN 31881, layer 4, horizon 5, 1974); right humerus fragment (ZIN 36655, layer 3e, horizon 2, 1977); radius fragment (ZIN 36658-6, mixed layers, 1978); right Mc5, sad. (ZIN 36653, layer 3, horizon 2, 1977); left talus (ZIN 36658-1, mixed layers, 1978); right calcaneus (ZIN 36658-2, mixed layers, 1978); several vertebrates, phalanges and small bone fragments. Total 130 fossil remains. 
Description. Remains of C. lupus are not numerous in the Kudaro caves, being represented by several teeth and postcranial bone fragments. Tooth dimensions and morphology provide a basis for division of these findings into two groups.

Specimens of the first group are confined to the lowermost horizons of layer 4 of Kudaro 3 Cave. Two isolated upper molars M1 (ZIN 31882; Fig. 6D, E) exceed in their length those of $C$. lunellensis from Kudaro 3 Cave. Their metastyles are less developed and antero-lingual cinguli are interrupted.

Two lower carnassial teeth $\mathrm{m} 1$ (ZIN 31881, 318832; Fig. 3F, G) from the same stratigraphical level correspond by the greatest length $(25.6 \mathrm{~mm}, 26.1 \mathrm{~mm})$ to the largest specimens of $C$. lunellensis from Lunel-Viel in France (Bonifay, 1971) and correspond to mean value of this measurement of C. lupus from Middle Pleistocene locality La Fage in France (Martin, 1975). They are smaller in this measurement than the teeth of the wolf in the sample from Binagady in Azerbaijan (27.0 $29.7 \mathrm{~mm}, n=5$ ) and are placed near the lower limit for the values of this measurement in the recent $C$. lupus from Caucasus (25.2-31.0 mm, $n=38)$. In the length and width, these teeth are similar to the teeth of $C$. lunellensis from Lunel-Viel. Both Kudaro specimens noticeably diverge in shape. ZIN 31881 has a deep talonid basin, well-developed entocolulid, and protocristid. These characters associate it with C. mosbachensis. The second specimen ZIN 31883-2 resembles this tooth in C. lupus: its talonid basin is shallow and more opened on the lingual side in comparison with C. mosbachensis; entocolulid and protocristid are absent. In the scatterplot of canonical scores, obtained as a result of Discriminant Analysis, both Kudaro specimens are placed between the samples of C. mosbachensis and $C$. lupus and fall into the limits of variation of the measurements of C. lupus (Fig. 7).

Gray wolves from the second group of fossil remains from upper stratigraphical levels show size and tooth morphology similar to those of the recent Caucasian subspecies C. lupus cubanensis Ognev, 1922. For example, one of these parameters is the alveolar width of the of upper-incisor row $(32 \mathrm{~mm})$ in the skull fragment ZIN 36684-5.

The maxilla ZIN 31880 (Fig. 1D) found in layer 3 of Kudaro 3 Cave is characterized by the greatest length of the upper carnassial tooth P4 $(24.6 \mathrm{~mm})$ inconspicuously exceeding that of corresponding teeth within the sample from the Binagady locality $(23.8 \mathrm{~mm}, 23.8 \mathrm{~mm}$, $n=2)$ and falling into the range of variation of this dimension in the recent $C$. lupus from Caucasus (22.8$29.0 \mathrm{~mm}, n=39$ ). Similar size of P4 is known for the Late Pleistocene wolves from the West-European localities (Bigaj, 1963); their contemporaries were larger in European Russia (Tab. 12). The anterolingual cingulum of M1 is interrupted. Its labial cingulum is well developed at the basis of metacone and extremely weak at the basis of protocone, as in the recent C. lupus.

Discriminant Analysis performed on the basis of three measurements of $\mathrm{m} 1$ (L, Ltal, W) reveals that nearly all fossil teeth of $C$. lupus from Binagady in Azerbaijan are located on the graph within the area of the sample of recent $C$. lupus from Caucasus (Fig. 7), with only two fossil specimens differing in the longer talonid.

Vereshchagin (1951) described the wolf from Binagady as the fossil subspecies C. lupus apscheronicus,

Table 12. Measurements (in mm) of maxilla in Late Pleistocene Canis lupus.

\begin{tabular}{|c|c|c|c|c|c|c|c|c|c|}
\hline \multirow{2}{*}{ Measurements } & \multirow{2}{*}{$\begin{array}{c}\text { Kudaro } \\
3 \text { Cave, } \\
\text { layer } 3 \\
\\
\text { ZIN } \\
31880\end{array}$} & \multicolumn{2}{|c|}{$\begin{array}{l}\text { Bunagady, } \\
\text { Azerbaijan }\end{array}$} & \multicolumn{2}{|c|}{$\begin{array}{c}\text { Kostenki, Voronezh } \\
\text { Region, European } \\
\text { Russia }\end{array}$} & \multirow{2}{*}{$\begin{array}{c}\begin{array}{c}\text { Bern- } \\
\text { burg, } \\
\text { Germany }\end{array} \\
\text { NHM } \\
38144\end{array}$} & \multicolumn{2}{|c|}{$\begin{array}{l}\text { Zoolithen, } \\
\text { Germany }\end{array}$} & \multirow{2}{*}{$\begin{array}{c}\text { Khapta- } \\
\text { shinsky } \\
\text { Yar, } \\
\text { Yakutia } \\
\text { Russia } \\
\text { GMY } \\
3728\end{array}$} \\
\hline & & $\begin{array}{c}\text { ZIN } \\
21919- \\
1\end{array}$ & $\begin{array}{c}\text { ZIN } \\
22384- \\
53\end{array}$ & $\begin{array}{c}\text { ZIN } 34327, \\
\text { "brevis" } \\
\text { holotype }\end{array}$ & $\begin{array}{c}\text { ZIN } \\
36233\end{array}$ & & $\begin{array}{c}\text { NHM } \\
403\end{array}$ & $\begin{array}{l}\text { NHM } \\
404 b\end{array}$ & \\
\hline Length P3-M1 & 53.6 & 51.6 & 53.2 & 59.9 & & & & & \\
\hline Length P4-M1 & 38.3 & 36.0 & 37.5 & 42.0 & & & & & \\
\hline Length M1-M2 & & 23.5 & 25.0 & 25.6 & & 25.7 & 24.0 & 27.3 & \\
\hline \multicolumn{10}{|c|}{ Teeth } \\
\hline P2 L & & 13.0 & & 15.7 & 14.8 & 14.5 & & & \\
\hline $\mathrm{W}$ & & 5.7 & & 6.8 & 6.7 & 6.3 & & & \\
\hline P3 L & 16.2 & 14.4 & & 17.5 & & 15.7 & & & 17.5 \\
\hline $\mathrm{W}$ & 7.0 & 6.5 & & 8.0 & & 7.2 & & & 7.3 \\
\hline P4 L & 24.6 & 23.8 & 23.8 & 27.7 & 27.2 & 25.5 & 23.8 & 26.8 & 26.7 \\
\hline Lpa & 16.8 & 15.7 & 15.1 & 19.3 & 18.4 & 8.1 & 7.8 & 9.4 & 8.5 \\
\hline $\mathrm{W}$ & 13.5 & 13.1 & 10.6 & 17.6 & 14.6 & 12.8 & 15.0 & 16.3 & 13.4 \\
\hline M1 L & 15.3 & 14.9 & 16.4 & 16.8 & 17.6 & 16.7 & 15.9 & 17.8 & 16.2 \\
\hline Lpa & 8.1 & 8.0 & 8.8 & 9.4 & 8.8 & 8.8 & 9.0 & 10.2 & 8.4 \\
\hline $\mathrm{W}$ & 19.8 & 19.4 & 20.4 & 22.1 & 20.6 & 20.2 & 18.0 & 21.0 & 20.5 \\
\hline M2 L & & 8.1 & 8.5 & 9.4 & & 9.7 & 7.9 & 9.7 & 9.5 \\
\hline $\mathrm{W}$ & & 13.5 & 12.8 & 13.3 & & 13.4 & 10.7 & 12.6 & 12.9 \\
\hline
\end{tabular}


Table 13. Measurements (in $\mathrm{mm}$ ) of lower cheek teeth in Late Pleistocene Canis lupus.

\begin{tabular}{|c|c|c|c|c|c|c|c|c|c|}
\hline \multirow{2}{*}{ Measurements } & \multirow{2}{*}{$\begin{array}{l}\text { Museum } \\
\text { number }\end{array}$} & \multicolumn{2}{|c|}{ p3 } & \multicolumn{2}{|c|}{ p4 } & \multicolumn{4}{|c|}{$\mathrm{m} 1$} \\
\hline & & $\mathrm{L}$ & $\mathrm{W}$ & $\mathrm{L}$ & $\mathrm{W}$ & $\mathrm{L}$ & Lpad & Ltald & $\mathrm{W}$ \\
\hline \multicolumn{10}{|c|}{ Caucasus } \\
\hline Kudaro 1, layer 4 & ZIN 36649-2 & 13.7 & 5.8 & & & & & & \\
\hline \multirow{2}{*}{ Kudaro 3, layer 4} & ZIN 31883-1,2 & 12.9 & 5.9 & 14.0 & 7.3 & 26.1 & 8.0 & 8.0 & 9.8 \\
\hline & ZIN 31881 & & & & & 25.6 & 7.8 & 6.7 & 9.6 \\
\hline \multirow{2}{*}{ M. Vorontsovskaya } & ZIN 31977 & & & 15.7 & 8.3 & & & & \\
\hline & ZIN 31978 & 13.8 & 7.2 & & & 29.3 & 10.5 & 8.5 & 11.7 \\
\hline \multirow{5}{*}{ Binagady } & ZIN 22384-43 & & & & & 29.7 & 10.5 & 8.5 & 11.5 \\
\hline & ZIN 22384-46 & 13.8 & 6.6 & 16.7 & 8.6 & 29.0 & 11.1 & 8.1 & 11.6 \\
\hline & ZIN 22384-47 & 13.7 & 7.4 & 15.4 & 8.5 & 28.0 & 9.7 & 6.2 & 11.4 \\
\hline & ZIN 22384-51 & 13.2 & 6.8 & 15.6 & 8.0 & 28.4 & 10.2 & 6.2 & 11.2 \\
\hline & ZIN 24408-1 & 12.5 & 6.3 & 15.3 & 7.6 & 27.0 & 9.6 & 7.1 & 11.1 \\
\hline $\begin{array}{l}\text { Il'skaya 1, Northern } \\
\text { Caucasus }\end{array}$ & ZIN 16569 & 14.9 & 7.2 & 16.1 & 8.5 & & & & \\
\hline \multicolumn{10}{|c|}{ Europe } \\
\hline Tornewton, England & NHM 40345 & 13.7 & 6.6 & 16.4 & 7.5 & 28.6 & - & 5.1 & 10.9 \\
\hline \multirow{2}{*}{$\begin{array}{l}\text { Kent's Cavern, } \\
\text { England }\end{array}$} & NHM 15636 & 14.5 & 7.0 & 16.3 & 8.4 & 29.5 & - & 7.9 & 12.2 \\
\hline & NHM 849 & 13.5 & 6.7 & 15.8 & 7.8 & & & & \\
\hline \multirow{3}{*}{ Zoolithen, Germany } & NHM 403a & 14.4 & 7.1 & 15.8 & 8.1 & 28.1 & - & 7.3 & 12.1 \\
\hline & NHM 404 & 14.3 & 7.1 & 16.5 & 8.5 & 29.0 & - & 7.2 & 12.1 \\
\hline & NHM 404c & 14.1 & 7.4 & 17.1 & 8.9 & 30.4 & - & 8.6 & 12.6 \\
\hline Bernburn, Germany & NHM 38144 & 13.6 & 6.7 & 16.5 & 7.9 & 28.8 & - & 7.7 & 11.2 \\
\hline \multirow{2}{*}{$\begin{array}{l}\text { Wierzchowska } \\
\text { Górna, Poland }\end{array}$} & ISAK 5967 & 12.8 & 5.7 & 14.8 & 6.4 & 24.5 & - & 7.5 & 10.1 \\
\hline & ISAK 5967 & 12.9 & 5.0 & 14.4 & 6.3 & 24.0 & - & 6.4 & 9.9 \\
\hline \multirow{2}{*}{$\begin{array}{l}\text { Vykhvatintsy, } \\
\text { Moldova }\end{array}$} & IZKM n/n & 13.2 & 6.6 & 15.9 & 8.4 & & & & \\
\hline & IZKM n/n & & & 16.1 & 8.1 & 27.0 & 9.7 & 7.9 & 11.5 \\
\hline
\end{tabular}

regarding the presence of alveolus of M3 in two specimens from 33 examined as a primitive trait. He noted that the wolf from Binagady is distinguished from the recent subspecies C. l. cubanensis by skull proportions: comparatively longer braincase, longer upper tooth row, wider palate, and shorter temporal constriction.

The upper molar M1 demonstrates the interrupted anterolingial cingulum in both examined skulls from Binagady (ZIN 21919-1 and 22384-53). The talonid of $\mathrm{m} 1$ is markedly worn in most mandibles. Two unworn specimens are characterized by the talonid basin shallower as compared to C. mosbachensis; the entoconulid is developed in ZIN 22381-40 and absent in ZIN 2238446. Measurements of $\mathrm{m} 1$ are given in Tab. 13.

Discussion. The paucity of bone remains of $C$. lupus in the Kudaro caves may be explained by their coming into the cave only on occasion. Wolf might have been sporadic prey of large cats (cave lion and leopard) using these karst cavities as shelters (see Baryshnikov, 2011).

Fossil remains of wolf occur throughout all Late Pleistocene cave layers, beginning with the earliest ones (lowermost horizons of layer 4 in Kudaro 3 Cave). The time of formation of these early levels is assigned to the Last Interglacial (Baryshnikov, 2002), but their age may be even older.

Wolf is represented in faunal lists for many Paleolithic sites of the Southern Caucasus (Bronzovaya, Bizonovaya, Medvezhiya and Verkhnyaya caves, Ortv- ala, Gvardzhikas-Klde in Georgia, Dashsalakhly in Azerbaijan, Erevanskaya in Armenia) and Northern Caucasus (Il'skaya, Barakaevskaya). The earliest record of the species in the Caucasus is associated with layer 5 of Azhych Cave in Azerbaijan, being ascribed to the second half of the Middle Pleistocene (Mindel-Riss and Riss) (Lioubine, 1989), and with the locality of Binagady near Baku dated by the Latest Interglacial (Eem) (Baryshnikov, 2002).

The appearance of C. lupus in Western Europe has been considered an important biostratigraphical marker of the late Middle Pleistocene (lupus-event; Azzaroli, 1983). However, this opinion was later replaced with the view that the most important events of the canid radiation took place earlier, during the latest Pliocene (Sardella \& Palombo, 2007).

The subspecies C. lupus lunellensis is frequently regarded as the earliest European wolf (Bonifay, 1971; Tedford et al., 2009). Other researchers give this wolf the status of a separate species $C$. lunellensis, associating the earliest record of $C$. lupus with the local fauna of the upper complexes of grotte Caune de L'Arago in France, which correlates with OIS 9, near 0.30-0.35 Ma (Palombo \& Valli, 2004), or in Pietra F.U. (about MIS 10-8) in Italy (Petronio et al., 2011). The earliest North American records of C. lupus are the arctic fossils from Yukon Territory (Old Crow) in Canada and from Alaska (Cripple Creek Sump), which date to the middle Pleistocene (Tedford et al., 2009). 
The subsequent evolution of C. lupus was accompanied by an increase in size and comparative lengthening of its muzzle. The large fossil wolf has been described on the basis of the material from the Upper Paleolithic site Kostenki 1 (layer 1) in European Russia as the extinct subspecies C. lupus brevis, which is characteristic by shortened limbs (Kuzmina \& Sablin, 1994). In the late Pleistocene, wolves inhabiting the northern part of Europe and the Arctic area of Siberia were not strictly predators, but also scavenged carcasses of mammoths, rhinos, and other megafauna. Presumably, they were more strongly pronounced osteophages than the recent animals (Baryshnikov et al., 2010).

The study of mitochondrial DNA of the recent $C$. lupus in Europe revealed two geographically overlapped haplogroups (Pilot et al., 2010). One of them also includes all fossil wolf samples from Western Europe. In North-America, this haplogroup was associated with a distinct wolf ecomorph becoming extinct to the end of the Pleistocene (Leonard et al., 2007).

Genus Cuon Hodgson, 1838

Cuon alpinus (Pallas, 1811)

$\uparrow$ Cuon alpinus caucasicus Baryshnikov, 1978

Referred specimens. Late Pleistocene, Kudaro 1 Cave: skull fragment (ZIN 34350, layers 3-4, 1957); right I3 (ZIN 36665, layer 3a, 1961); right C1 (ZIN 36660, layer 3a, 1957; ZIN 36662, layer 3b, 1958), left C1 (ZIN 36736-1, layer 3b, 1961); left P1 (ZIN 366612, layer 3a, 1958), left P1 (ZIN 36659, layer 3c-4, 1957); left mandible with p4-m1 (ZIN 34339, layer 3a, 1959); right $\mathrm{c} 1$ (ZIN 36736-2, layer 3b, 1961); right $\mathrm{p} 1$ (ZIN 36661-1, layer 3a, 1958); atlas (ZIN 36738, layer $X$, horizon 4, 1978); left humerus (ZIN 36669, layer 3c, 1961); humerus fragment (ZIN 36667, mixed layers, 1977); left ulna ((ZIN 36733-1, layer 4, 1958); right ulna (ZIN 36739, layer X-2, horizon 1, 1980); left scaphoid (ZIN 36664-2, layer 3, 1959); right pelvis (ZIN 36668, layer X, horizon 4, 1978); left tibia (ZIN 36737-2, layer 3c, 1961); left calcaneus (ZIN ; 367301, layer 3c, 1958); right Mt2 (ZIN 36731-1, layer 3c-4, 1958); left Mt3 (ZIN 36663, layer 4, 1958); left Mt4 (ZIN 3666, lens “Z”, 1961).

Kudaro 3 Cave: left maxilla with P4-M1 (ZIN34343, layers 3-4, 1975); left C1 (ZIN 36705-6, mixed layers, 1978; 36708-6, mixed layers, 1957); right C1 (ZIN 36684-4, layers 3-4, 1975); left mandible with p3-m1 (ZIN 31241, layer 3, horizon 3, 1959, holotype); left mandibles with p4-m1 (ZIN 34340, layer 4, horizon 2, 1974; 34342, layers 3-4, 1975); left mandible with p2, m1 (ZIN 34341, layers 3-4, 1975); left mandible with p1, p2, p4 (ZIN 34338, layer 4, horizon 3, 1959); left mandible fragment with p2 (ZIN 36675-1, layer 3, 1959); right mandible with p1, p4-m1 (ZIN 34344, mixed layers, 1978); left c1 (ZIN 36683, layer 4, horizon 3, 1974); right c1 (ZIN 36678, layer 3, horizon 2, 1974; 36696-1, layer 3e, horizon 1, 1977); right p1 (ZIN 36699, layer 3a, 1978); right p2 (ZIN 36703-2, layer 4d, 1978); axis (ZIN 36703-1, layer 4d, 1978; $36677-1$, layer 3 , horizon 1,$1974 ; 36679-2$, layer 3 , horizon 2, 1974; 36682-1, layer 4, horizon 2, 1974; 36697-1, layer 3e, 1977); right scapula fragments (ZIN 36705-3, mixed layers, 1977); left scapula fragments (ZIN 36692-1, layer 3d, 1977; 36696-3, layer 3e, horizon 1, 1977; 36708-4, mixed layers, 1957;); left humerus (ZIN 31241-2, layer 3, horizon 3, 1959; 36674, layer 3 , horizon 5 , 1959; 36684-1, layers 3-4, 1975; 367081, mixed layers, 1957); right humerus (ZIN 36679-1, layer 3, horizon 2, 1974; 36708-3, mixed layers, 1977); left ulna (ZIN 36698-1, layer 4a, 1977; 36677-2, layer 3 , horizon 1, 1974; 31241-3, layer 3, horizon 3, 1959; 36705-7, mixed layers, 1978); right ulna (ZIN 36670-1, layer 2, 1959; 36697-2, layer 3e, 1977); left radius (ZIN 31241-4, layer 3, horizon 3, 1959; 36705-4, mixed layers, 1978); right radius (ZIN 36698-2, layer 4a, 1977; 36670-2, layer 2, 1959); left pisiform (ZIN 36704, layer 4d, 1979); left Mc2 (ZIN 36681-1, layer 3, horizon 4, 1974; 36702-4, layer 4ab, 1978); right Mc3 (ZIN 36673-3, layer 3, horizon 4, 1959); left Mc4 (ZIN 36698-4, layer 4a, 1977); left Mc5 (ZIN 36684-2, layers 3-4, 1975); right Mc5 (ZIN 36692-3, layer 3d, 1977); right pelvis (ZIN 36688-1, layer 3c, horizon 1, 1977); pelvis fragments (ZIN 31241-5, layer 3, horizon 3, 1959; 36681-3, layer 3, horizon 4, 1974); right femur (ZIN 36692-2, layer 3d, 1977; 36700-2, layer 3e, horizon 1, 1978); patella (ZIN 36688-5, layer 3c, horizon 1, 1977); left tibia (ZIN 36705-1, mixed layers, 1978; 36708-2, mixed layers, 1957); left tibia (ZIN 36702-3, layer 4ab, 1978); fibula fragments (ZIN 36691-4, layer 3c, horizon 3, 1977; 36685-2, layers 3-4, 1975); left talus (ZIN 36694-1, layer 3e, horizon 1, 1977; 366912, layer 3c, horizon 3, 1977); right talus (ZIN 36680-5, layer 3, horizon 3, 1974; 36695-1, layer 3e, horizon 1, 1977; 36693, layer 3d, 1977); left calcaneus (ZIN 36701, layer 3e, horizon 2, 1978; 36706, layer 4d, 1980; 366711 , layer 3, horizon 1,$1959 ; 36672-2$, layer 3, horizon 2 , 1959); right calcaneus (ZIN 36676-1, layers 2-3, 1974); left navicular (ZIN 36676-3, layers 2-3, 1974; 366924, layer 3d, 1977); right navicular (ZIN 36691-3, layer 3c, horizon 3, 1977); left Mt2 (ZIN 36681-2, layer 3, horizon 4, 1974; 36700-1, layer 3e, horizon 1, 1978; 36671-2, layer 3, horizon 1, 1959); right Mt2 (ZIN 36698-3, layer 4a, 1977); left Mt3 (ZIN 36676-2, layers 2-3, 1974; 36691-1, layer 3c, horizon 3, 1977); right Mt3 (ZIN 36672-1, layer 3, horizon 2, 1959; 36685-1, layers 3-4, 1975); left Mt4 (ZIN 36708-5, mixed layers, 1957; 36684-3, layers 3-4, 1975; 367058 , mixed layers, 1977; 36687, layer 4, horizon 5, 1975); right Mt4 (ZIN 36671-3, layer 3, horizon 1, 1959; 36702-1, layer 4ab, 1978); left Mt5 (ZIN 36682-4, layer 4, horizon 2, 1974; 36705-5, mixed layers, 1978; 36686, layer 4, horizon 3, 1975); right Mt5 (ZIN 366891, layer 3, horizon 3, 1974; 36690-1, layer 3c, horizon 2, 1977; 36705-2, mixed layers, 1978; 36707, mixed layers, 1981). Total is 205 fossil remains.

Description. The fossil skull fragment ZIN 34350 resembles skulls of the recent subspecies $C$. a. alpinus 
Table 14. Measurements (in mm) of maxilla Cuon alpinus.

\begin{tabular}{|c|c|c|c|c|c|c|c|c|c|}
\hline \multirow{3}{*}{ Measurements } & $\begin{array}{c}\text { C. a. caucasicus, } \\
\text { Late Pleistocene }\end{array}$ & \multicolumn{4}{|c|}{ C. a. alpinus, Recent } & \multicolumn{3}{c|}{ C. a. hespericus, Recent } \\
\cline { 2 - 11 } & $\begin{array}{c}\text { Kudaro 3, } \\
\text { layers 3-4 }\end{array}$ & \multicolumn{3}{|c|}{ Russian Far East } & \multicolumn{5}{c|}{ Tian-Shan and Altai } \\
\cline { 2 - 11 } & ZIN 34343 & $n$ & lim & M & SD & $n$ & lim & M & SD \\
\hline Length P4-M1 & 31.7 & 9 & $30.6-33.2$ & 31.80 & 1.00 & 9 & $30.1-33.0$ & 31.47 & 1.01 \\
\hline Teeth & & & & & & & & & \\
\hline P4 L & 21.2 & 9 & $19.9-21.6$ & 20.73 & 0.62 & 9 & $19.8-21.6$ & 20.61 & 0.66 \\
\hline Lpa & 12.9 & 9 & $12.2-13.7$ & 12.93 & 0.42 & 9 & $12.2-14.5$ & 12.86 & 0.70 \\
\hline W & 10.5 & 9 & $9.3-10.9$ & 10.10 & 0.57 & 9 & $9.0-10.5$ & 9.80 & 0.46 \\
\hline M1 L & 13.0 & 9 & $12.3-14.2$ & 13.08 & 0.76 & 9 & $12.2-13.9$ & 13.08 & 0.50 \\
\hline Lpa & 7.1 & 9 & $6.7-7.9$ & 7.19 & 0.40 & 9 & $6.8-7.9$ & 7.42 & 0.35 \\
\hline W & 14.2 & 9 & $13.0-14.2$ & 13.63 & 0.40 & 9 & $13.3-14.6$ & 13.79 & 0.44 \\
\hline
\end{tabular}

Table 15. Measurements (in mm) of upper and lower canines and premolars Late Pleistocene Cuon alpinus.

\begin{tabular}{|c|c|c|c|c|c|c|c|c|c|c|c|}
\hline \multirow{3}{*}{ Localities } & \multirow{3}{*}{$\begin{array}{c}\text { Museum } \\
\text { number }\end{array}$} & \multicolumn{10}{|c|}{ Measurements, mm } \\
\hline & & \multicolumn{2}{|c|}{$\mathrm{C} 1$} & \multicolumn{2}{|c|}{ P1 } & \multicolumn{2}{|c|}{$\mathrm{cl}$} & \multicolumn{2}{|c|}{$\mathrm{p} 1$} & \multicolumn{2}{|c|}{$\mathrm{p} 2$} \\
\hline & & $\mathrm{L}$ & $\mathrm{W}$ & $\mathrm{L}$ & $\mathrm{W}$ & $\mathrm{L}$ & $\mathrm{W}$ & $\mathrm{L}$ & W & $\mathrm{L}$ & $\mathrm{W}$ \\
\hline \multicolumn{12}{|c|}{ Caucasus } \\
\hline \multirow{4}{*}{ Kudaro 1} & ZIN 36660 & 10.4 & 6.5 & & & & & & & & \\
\hline & ZIN 36662 & 10.6 & 6.7 & & & & & & & & \\
\hline & ZIN 36735 & 11.1 & 6.8 & & & & & & & & \\
\hline & ZIN 36736-1 & 10.8 & 6.9 & & & & & & & & \\
\hline \multirow{3}{*}{ Kudaro 3} & ZIN 36684-4 & 11.0 & 6.8 & & & & & & & & \\
\hline & ZIN 36708-6 & 11.2 & 6.8 & & & & & & & & \\
\hline & ZIN 36705-6 & 10.7 & 7.0 & & & & & & & & \\
\hline \multirow{2}{*}{ Kudaro 1} & ZIN 36661-2 & & & 6.8 & 4.9 & & & & & & \\
\hline & ZIN 36659 & & & 6.4 & 4.7 & & & & & & \\
\hline Kudaro 1 & ZIN 36736-2 & & & & & 10.8 & 6.7 & & & & \\
\hline \multirow{3}{*}{ Kudaro 3} & ZIN 36683 & & & & & 10.9 & 7.3 & & & & \\
\hline & ZIN 36678 & & & & & 11.3 & 7.1 & & & & \\
\hline & ZIN 36696-1 & & & & & 10.9 & 6.7 & & & & \\
\hline Kudaro 1 & ZIN 36661-1 & & & & & & & 5.2 & 3.8 & & \\
\hline \multirow{3}{*}{ Kudaro 3} & ZIN 36699 & & & & & & & 5.9 & 3.8 & & \\
\hline & ZIN 36703-2 & & & & & & & & & 9.4 & 5.2 \\
\hline & ZIN 36675-1 & & & & & & & & & 8.8 & 5.1 \\
\hline \multicolumn{12}{|c|}{ Europe } \\
\hline \multirow{2}{*}{$\begin{array}{l}\text { Caune de l'Arago, } \\
\text { France }\end{array}$} & MHP 1558 & & & & & 10.7 & 6.6 & & & & \\
\hline & MHP 6214 & & & & & 10.3 & 6.9 & & & & \\
\hline
\end{tabular}

by its greatest width at the occipital condyles $(41.1 \mathrm{~mm})$ and by the height of the occiput $(64.6 \mathrm{~mm})$. The maxilla ZIN 34343 (Fig. 1C) is indistinguishable in size and shape of the upper molars from continental subspecies of the recent $C$. alpinus (Tab. 14), being, however, markedly smaller in comparison with the fossil subspecies C. a. antiquus Mattew et Granger, 1923 from the late Middle Pleistocene of China (Colbert \& Hoojer, 1953). The comparison between the Kudaro find and European fossil dholes in the length and width of M1, as well as in the proportion of these dimensions, revealed it to be more similar to C. a. europaeus Bourguignat, 1868 from the Late Pleistocene than to $C$. priscus Thenius, 1954 and C. a. fossilis Nehring, 1890 from the Middle Pleistocene (Nehring, 1890; Thenius, 1954; Argant, 1991; Pérez Ripoll et al., 2010).
The width of the upper canine $(6.5-7.0 \mathrm{~mm}, n=5$; Tab. 15) does not exceed the bounds of its variation in recent $C$. alpinus (4.9-6.9 $\mathrm{mm}, n=17$ ); however, the mean value of this measurement in the fossil sample is considerably higher, which may be explained by predominance of males within this sample. Measurements of the Kudaro specimens are similar to those of the upper canine in the Late Pleisocene $C$. alpinus from the localities of Parpalló and Santa Maira in Spain (Pérez Ripoll et al., 2010).

A series comprising seven fossil mandibles (ZIN 31241, 34338-34342, 34344; Fig. 5C-F, 8) displayed no morphometric difference from the recent $C$. alpinus. The length of the tooth row $\mathrm{p} 1-\mathrm{m} 1$ is analogous to that of the nominative subspecies C. a. alpinus (60.7-67.2, $n=7)$; meanwhile, the $\mathrm{p} 1-\mathrm{m} 1$ row was found to be 


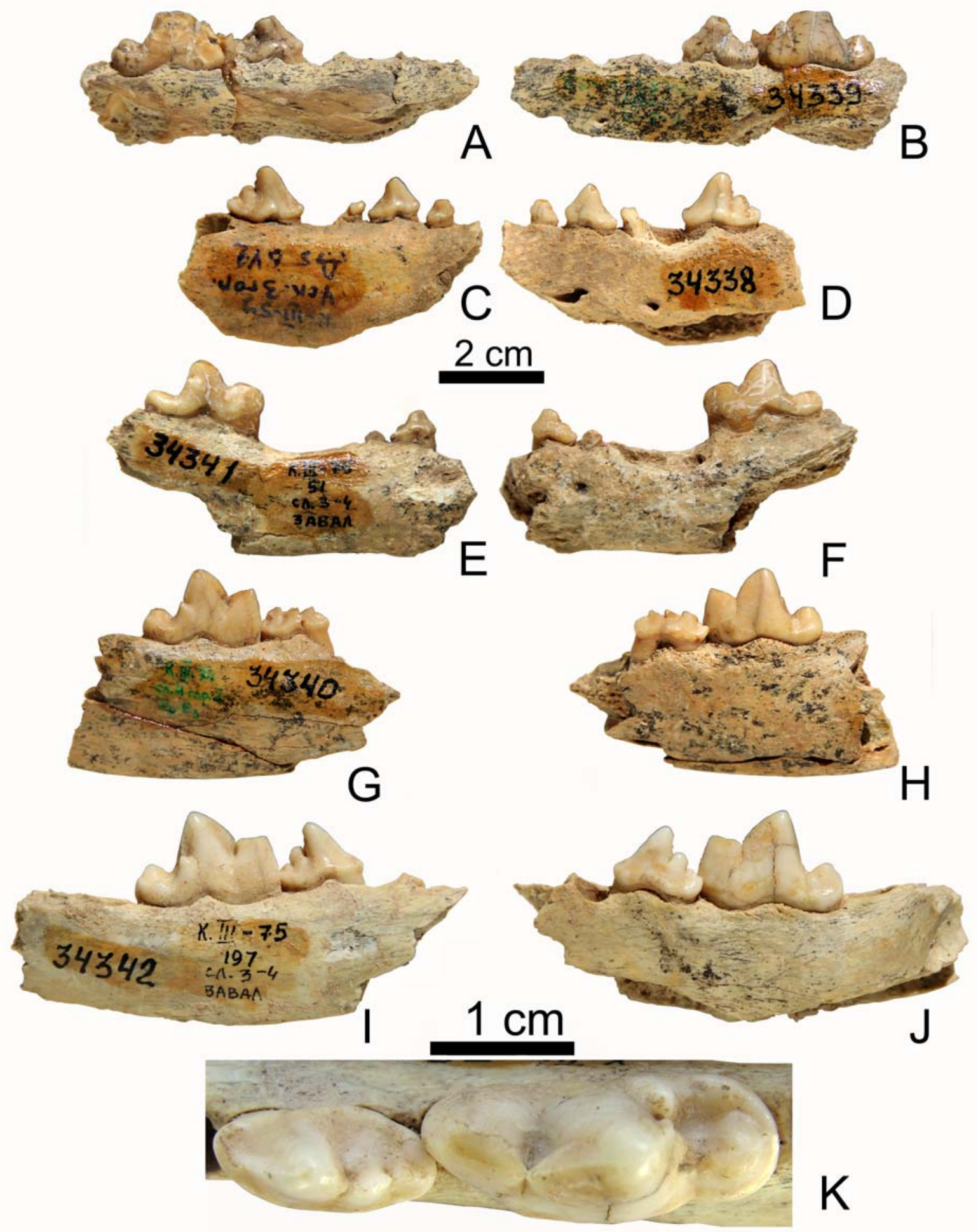

Fig. 8. Mandibular fragments of Cuon alpinus caucasicus from Kudaro 3; labial (B, D, F, H, J), lingual (A, C, E, G, I) and occlusal (K) views.

A, B - ZIN 34339; C, D — ZIN 34338; E, F — ZIN 34341; G, H - ZIN 34340; I-K — ZIN 34342. 
Table 16. Measurements (in mm) of mandibles Cuon alpinus.

\begin{tabular}{|c|c|c|c|c|c|c|c|c|c|}
\hline \multirow{2}{*}{ Measurements } & \multirow{2}{*}{$\begin{array}{c}\text { Kudaro 3, } \\
\text { layer 3 } \\
\text { ZIN } \\
\text { 31341, } \\
\text { holotype } \\
\end{array}$} & \multirow{2}{*}{$\begin{array}{c}\begin{array}{c}\text { Kudaro } 3, \\
\text { mixed } \\
\text { layers }\end{array} \\
\text { ZIN } 34344\end{array}$} & \multicolumn{2}{|c|}{$\begin{array}{l}\text { Kudaro 3, } \\
\text { layers 3-4 }\end{array}$} & \multicolumn{2}{|c|}{$\begin{array}{c}\text { Kudaro } 3, \\
\text { layer } 4\end{array}$} & \multirow{2}{*}{$\begin{array}{c}\begin{array}{c}\text { Kudaro 1, } \\
\text { layer 3a }\end{array} \\
\text { ZIN } \\
34339\end{array}$} & \multicolumn{2}{|c|}{$\begin{array}{c}\text { La Caune de l'Arago, } \\
\text { France }\end{array}$} \\
\hline & & & $\begin{array}{c}\text { ZIN } \\
34342\end{array}$ & $\begin{array}{c}\text { ZIN } \\
34341\end{array}$ & $\begin{array}{c}\text { ZIN } \\
34338\end{array}$ & $\begin{array}{c}\text { ZIN } \\
34340\end{array}$ & & $\begin{array}{l}\text { MHP } \\
1558\end{array}$ & $\begin{array}{l}\text { MHP } \\
6214\end{array}$ \\
\hline Length $\mathrm{p} 1-\mathrm{m} 2$ & & 68.3 & & & & & & 70.6 & 69.9 \\
\hline Length $\mathrm{p} 1-\mathrm{m} 1$ & & 61.4 & & & 65.1 & & 65.1 & & \\
\hline Length $\mathrm{p} 2-\mathrm{m} 1$ & & & & 55.6 & & & & 56.6 & 56.2 \\
\hline Length $\mathrm{p} 3-\mathrm{m} 1$ & 46.3 & & & 46.3 & & & & 46.1 & 46.1 \\
\hline Length $\mathrm{p} 4-\mathrm{m} 1$ & 35.6 & 35.1 & 35.5 & & & 35.9 & 36.4 & 35.3 & 35.5 \\
\hline Length $\mathrm{p} 1-\mathrm{p} 4$ & & 40.4 & & & 43.2 & & 43.7 & 41.9 & \\
\hline $\begin{array}{l}\text { Height before } \\
\text { m1 }\end{array}$ & 22.7 & 23.7 & & $\begin{array}{c}\text { ca. } 21 . \\
7\end{array}$ & & 25.7 & & & 23.8 \\
\hline \multicolumn{10}{|c|}{ Teeth } \\
\hline p1 L & & 5.6 & & & 5.6 & & & 5.5 & 5.7 \\
\hline $\mathrm{W}$ & & 3.6 & & & 3.6 & & & 3.5 & 3.9 \\
\hline p2 L & & & & 8.7 & 9.8 & & & 9.4 & 9.5 \\
\hline $\mathrm{W}$ & & & & 4.7 & 5.1 & & & 4.6 & 4.9 \\
\hline p3 L & 11.0 & & & & & & & 10.5 & 10.4 \\
\hline $\mathrm{W}$ & 5.5 & & & & & & & 5.0 & 5.7 \\
\hline $\mathrm{p} 4 \mathrm{~L}$ & 13.9 & 14.0 & 13.7 & & 14.6 & 14.0 & 14.4 & 13.8 & - \\
\hline $\mathrm{W}$ & 6.8 & 6.7 & 6.7 & & 7.2 & 6.5 & 7.6 & 6.6 & 6.7 \\
\hline $\mathrm{m} 1 \mathrm{~L}$ & 22.8 & 22.9 & 22.5 & 22.6 & & 22.8 & 23.6 & 22.2 & 23.0 \\
\hline Lpad & 8.0 & 8.0 & 8.5 & 8.1 & & 8.2 & 8.7 & 8.0 & 7.2 \\
\hline Ltald & 6.7 & 6.3 & 6.8 & 6.5 & & 6.5 & 6.7 & 6.0 & 5.9 \\
\hline $\mathrm{W}$ & 9.3 & 8.9 & 9.2 & 8.8 & & 8.7 & 9.1 & 8.8 & 8.8 \\
\hline
\end{tabular}

noticeably shorter in other recent subspecies. A marked metric likeness of Kudaro mandibles to fossil specimens from grotte La Caune de l'Arago in France is observed (Tab. 16). The height of mandible at $\mathrm{m} 1$ in the Kudaro samples is somewhat lower than that in the fossil subspecies C. a. europaeus (Bonifay, 1971).

Lower cheek teeth from the Kudaro caves are more robust than in recent subspecies of $C$. alpinus, excepting their largest representative, C. a. alpinus. The latter subspecies, however, is characterized by smaller (on average) premolar width. A comparison with fossil specimens from European localities revealed p4 and $\mathrm{m} 1$ to be markedly longer in $C$. priscus (Hundsheim, Mosbach, Petralona) and in C. alpinus fossilis (Heppenloch, Lunel-Viel) than in C. a. caucasicus (Thenius, 1954; Adam, 1959; Bonifay, 1971; Kurtén \& Poulianos, 1977). Similarly long $\mathrm{p} 4$ and $\mathrm{m} 1$ were found in Cuon sp. from Cripple Creek Sump in Alaska (Youngmann, 1993).

The resemblance with $C$. a. caucasicus in dimensions of the cheek teeth was established for $C$. alpinus cf. priscus from La Caune de l'Arago (Tab. 16) and for two mandibles from the Middle Pleistocene locality Trinchera-Galería in Sierra de Atapuerca, Spain, which were assigned to C. a. europaeus (Cervera, 1992).

In the Late Pleistocene European subspecies $C$. $a$. europaeus, the length of lower carnassial tooth $\mathrm{m} 1$ is similar to that of C. a. caucasicus; however, the lower premolar $\mathrm{p} 4$ of the former subspecies is somewhat longer (Schütt, 1973; Cordy, 1983) (Fig. 9). The ratio of $\mathrm{p} 4$ length to $\mathrm{m} 1$ length is markedly larger in $C$. $a$. europaeus $(63.5-67.0 \%, n=5)$ than this index in $C$. $a$. caucasicus $(60.9-61.4 \%, n=5)$ and in the specimen from Trinchera-Galería $(60.8 \%, n=1)$. In C. alpinus from the Late Pleistocene localities of Iberian Peninsula, values of this index vary noticeably $(58.9-65.3 \%$, $n=5$; according measurements in Pérez Ripoll et al., 2010); however, its maximum values are comparable to those of $C$. a. europaeus from other European sites. Among recent subspecies, C. a. caucasicus may by compared with this index to C. a. alpinus (58.1-61.2\%, $n=6)$; at the same time, other subspecies exhibit this proportion less markedly $(50.9-59.5 \%, n=28)$ (Baryshnikov, 1995).

The Kudaro specimens possess one cusp on the lower premolars p1; $\mathrm{p} 2$ is characterized by a high main cusp (protoconid) with a small cuspid on the labiodistal side; $\mathrm{p} 4$ has a robust protoconid, a diminutive anterior cusp, and two posterior cuspids. Fossil specimens from other localities show size variation of the anterior cusp of p4 (Tedford et al., 2009; Pérez Ripoll et al., 2010); in the recent $C$. alpinus, this cusp is small.

Lower carnassial teeth $\mathrm{ml}$ from the Kudaro cave collection exhibit a well-developed metaconid, which may be occasionally reduced in the recent $C$. alpinus (in 7 of 41 specimens). The cingulid, running along the lingual wall of talonid, frequently expands beyond the posterior margin of the latter and may reach the hypo- 


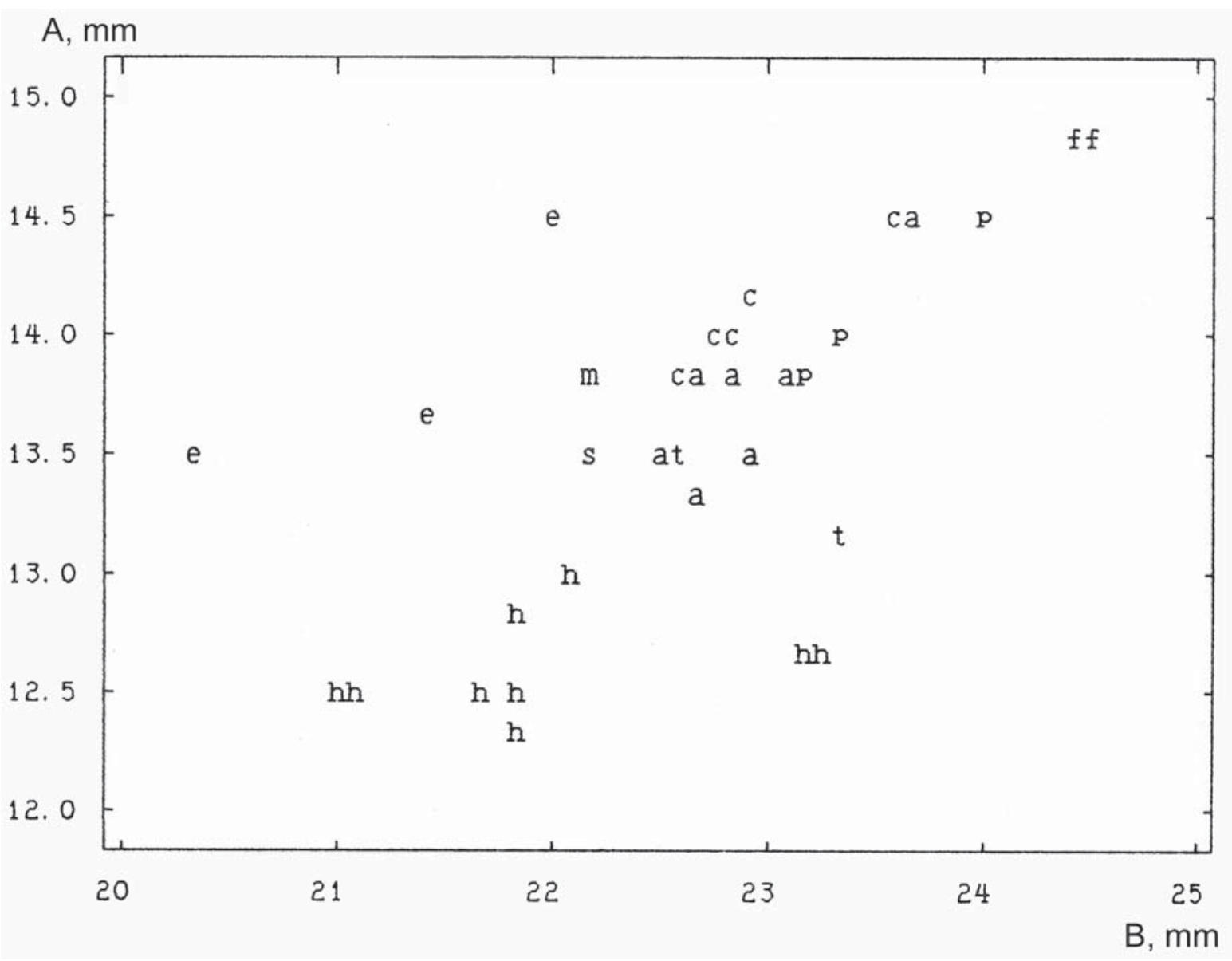

Figure 9. Correlation between greatest length of $\mathrm{p} 4$ (A) and greatest length of $\mathrm{m} 1$ (B) in Cuon alpinus.

Pleistocene: $\mathrm{c}-$ C. a. caucasicus, Kudaro 1 and Kudaro 3, e - C. a. europeus, Čertova Dira, Sipka, Chokier, f - C. a. fossilis, Heppenloch, Lunel-Viel, $\mathrm{m}-$ C. alpinus cf. priscus, Arago, $\mathrm{p}-$ C. priscus, Hundsheim, Mosbach, s - C. a. europeus, Atapuerca, $\mathrm{t}-$ C. a. antiquus, Yenchingkou. Recent: a - C. a. alpinus, h-C. a. hespericus.

conid base (in recent C. alpinus, it generally does not spread beyond the posterior margin of talonid). The hypoconid is large (Fig. 8K). The entoconid is not developed; a small tubercle (in 4 of 5 cases), which may be a rudimentary entoconid, is visible at its place. It is characteristic of $C$. priscus and is recorded in $C$. $a$. fossilis from Lunel-Viel in France (Thenius, 1954; Bonifay, 1971). The recent $C$. alpinus lacks this small tubercle and it is also absent on fossil teeth from Trinchera-Galería, Obarreta and Cova Negra in Spain (Cervera, 1992; García, 2003; Pérez Ripoll et al., 2010).

Summarizing, although the $\mathrm{m} 1$ of $C$. a. caucasus from Kudaro caves resembles C. a. europaeus from the Late Pleistocene in length and width, the shape of the talonid of this tooth suggests a possible link between the Caucasian subspecies and the archaic species $C$. fossilis (including C. priscus) from the Middle Pleistocene.

The best-preserved Kudaro mandible retains the alveolus of $\mathrm{m} 2$; no traces of $\mathrm{m} 3$ are observed. Judging from the alveolus, $\mathrm{m} 2$ had fused roots with a marked groove at their juncture on the labial side. In C. priscus, the roots are separate (Thenius, 1954). Adult individu- als of the recent $C$. alpinus generally show fused roots of $\mathrm{m} 2$; however, these roots are found to be separated in several young animals.

The material from Kudaro caves includes elements of all parts of the vertebral column, with the exception of the tail. Most of the fossil vertebrae are larger in size than those of recent $C$. alpinus, more similar, at the same time, in their robusticity to $C$. alpinus instead of C. lupus (Baryshnikov, 1995). The first cervical vertebra (atlas) with small transversarium and several specimens of second cervical vertebra (axis) with widened anterior portion of the processus spinosus (which is characteristic of C. alpinus) were examined (Tab. 17; Fig. 10A).

Limb bones from the Kudaro collection (Figs 10 13) exceed corresponding bones of examined skeletons of recent dholes in size, being similar to those of the Late Pleistocene $C$. alpinus from the Iberian localities (Pérez Ripoll et al., 2010). Diagnostic characters reflecting osteological differences between C. alpinus and $C$. lupus were discussed by Gromova (1950) and Pérez Ripoll et al. (2010). Two complete humeri (ZIN 36708-1, 36708-3; Fig. 11A, B) are comparable in their 
Table 17. Measurements (in mm) of cervical vertebrates of Cuon alpinus caucasicus.

\begin{tabular}{|c|c|c|c|c|c|c|c|c|c|c|}
\hline \multirow{2}{*}{ Localities } & \multirow{2}{*}{$\begin{array}{l}\text { Museum } \\
\text { number }\end{array}$} & \multicolumn{9}{|c|}{ Measurements } \\
\hline & & GL & BFcr & BFcd & LAd & $\mathrm{H}$ & LCDe & $\mathrm{LAPa}$ & SBV & BPacd \\
\hline \multicolumn{11}{|c|}{ Atlas } \\
\hline Kudaro 1, layer X & ZIN 36738 & 40.1 & 42.3 & 34.9 & 20.4 & 31.0 & & & & \\
\hline \multicolumn{11}{|c|}{ Axis } \\
\hline \multirow{2}{*}{ Kudaro 3, layer 4} & ZIN 36682-1 & & 34.0 & 19.0 & & ca.42 & & 57.5 & 26.2 & 33.7 \\
\hline & ZIN 36703-1 & & 35.9 & 23.1 & & 45.9 & 56.1 & 60.6 & 28.9 & 40.7 \\
\hline \multirow{3}{*}{ Kudaro 3, layer 3} & ZIN 36697 & & 33.5 & 19.8 & & 43.1 & 59.1 & & 26.2 & 32.0 \\
\hline & ZIN 36677-1 & & 32.0 & ca. 20 & & ca.43 & & 58.9 & 21.5 & 34.6 \\
\hline & ZIN 36679-2 & & 32.9 & 22.2 & & & & & 21.0 & \\
\hline
\end{tabular}
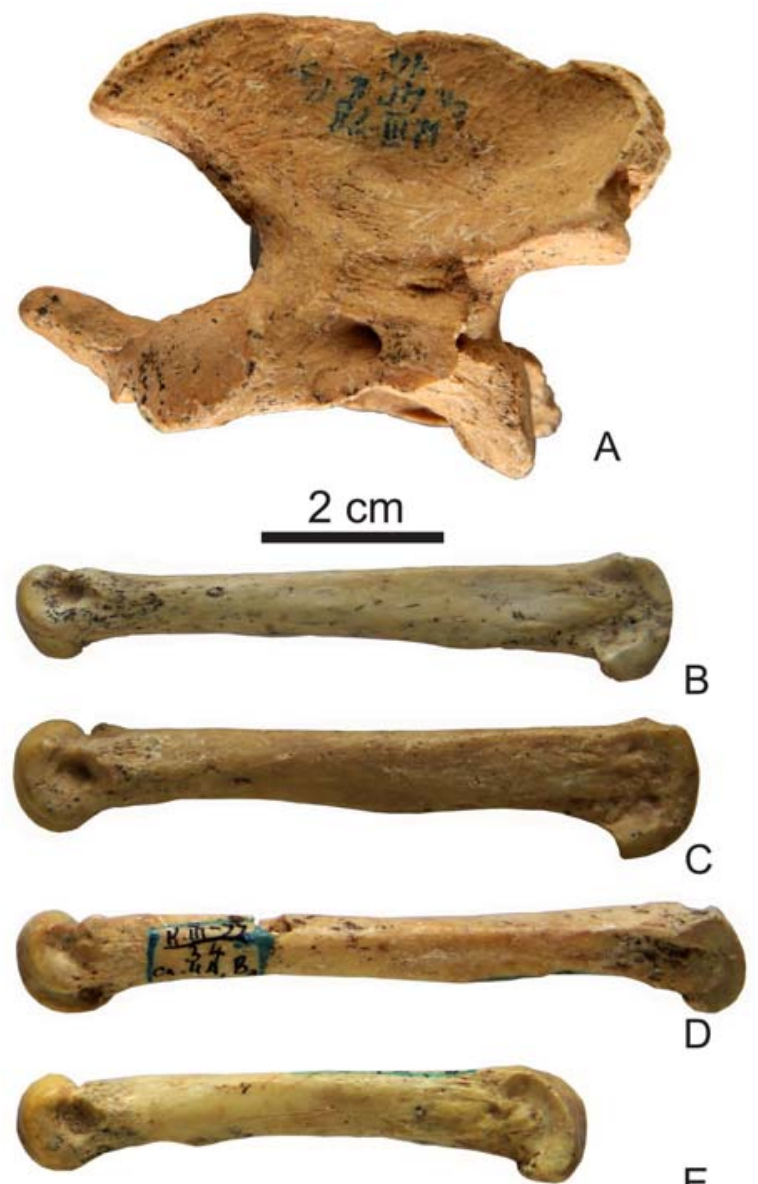

E

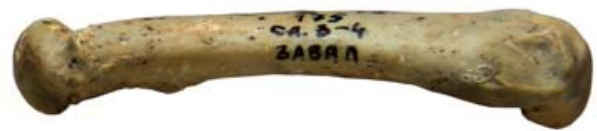

F

Figure 10. Second cervical vertebra (axis) (A) and metacarpal bones (B-F) of Cuon alpinus caucasicus from Kudaro 3 Cave; lateral (A-D, F) and medial (E) views.

A - ZIN 36703-1; B - left Mc2, ZIN 36702-4; C - left Mc2, ZIN 36681-1; D — left Mc4, ZIN 36698-4; E — right Mc5, ZIN 366923; F — left Mc5, ZIN 36684-2.

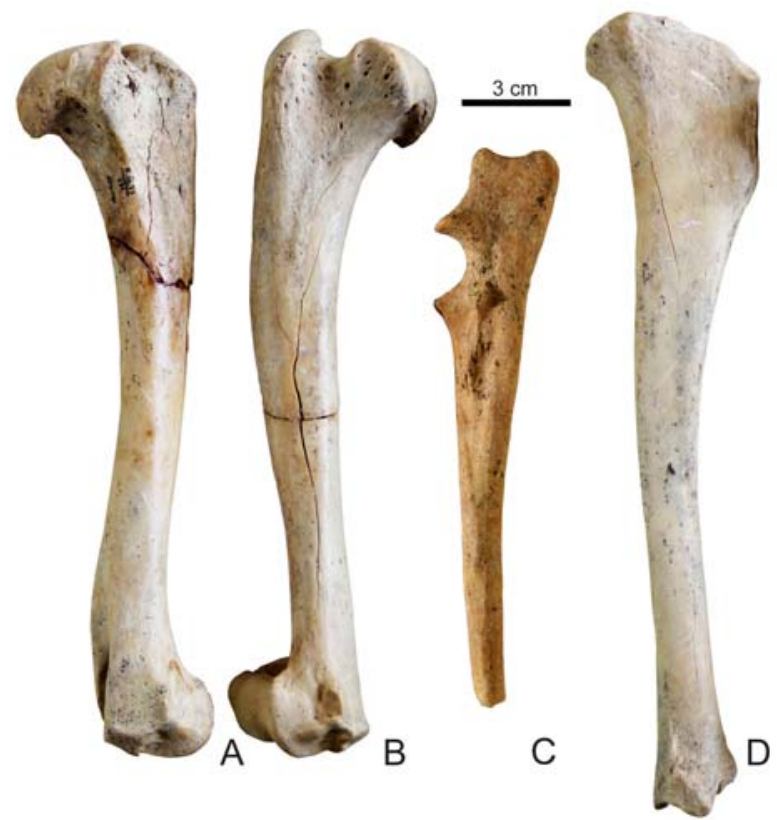

Figure 11. Right (A) and left (B) humerus, left ulna (C) and left tibia (D) of Cuon alpinus caucasicus from Kudaro 3 Cave; caudomedial (A-B), lateral (C) and medial (D) views. A - ZIN 36708-3; B - ZIN 36708-1; C - ZIN 36698-1; D - ZIN 36708-2.

greatest length to bones of $C$. lupus from Binagady in Azerbaijan, the width of fossa olecrani in former bones being at the same time approximately equal to its length, and their foramen supratrochleare occupying more than half the space of the fossa olecrani, as in C. alpinus. The radius (Fig. 11C) shows tuber olecranoni slightly widened backwards (in C. lupus it is markedly widened in the same direction); two ridges extend along the radial shaft from the median prominence restricting incisura radii (a single ridge is observed in C. lupus). The longitudinal ridge in the middle portion of the posterior surface of the tibial shaft (Fig. 11D) runs along the centerline or medial to it; this ridge is absent in C. lupus. Bones of the limb distal parts are more robust and shorter in C. a. caucasus as compared to those of C. lupus (Tab. 18, 19). 

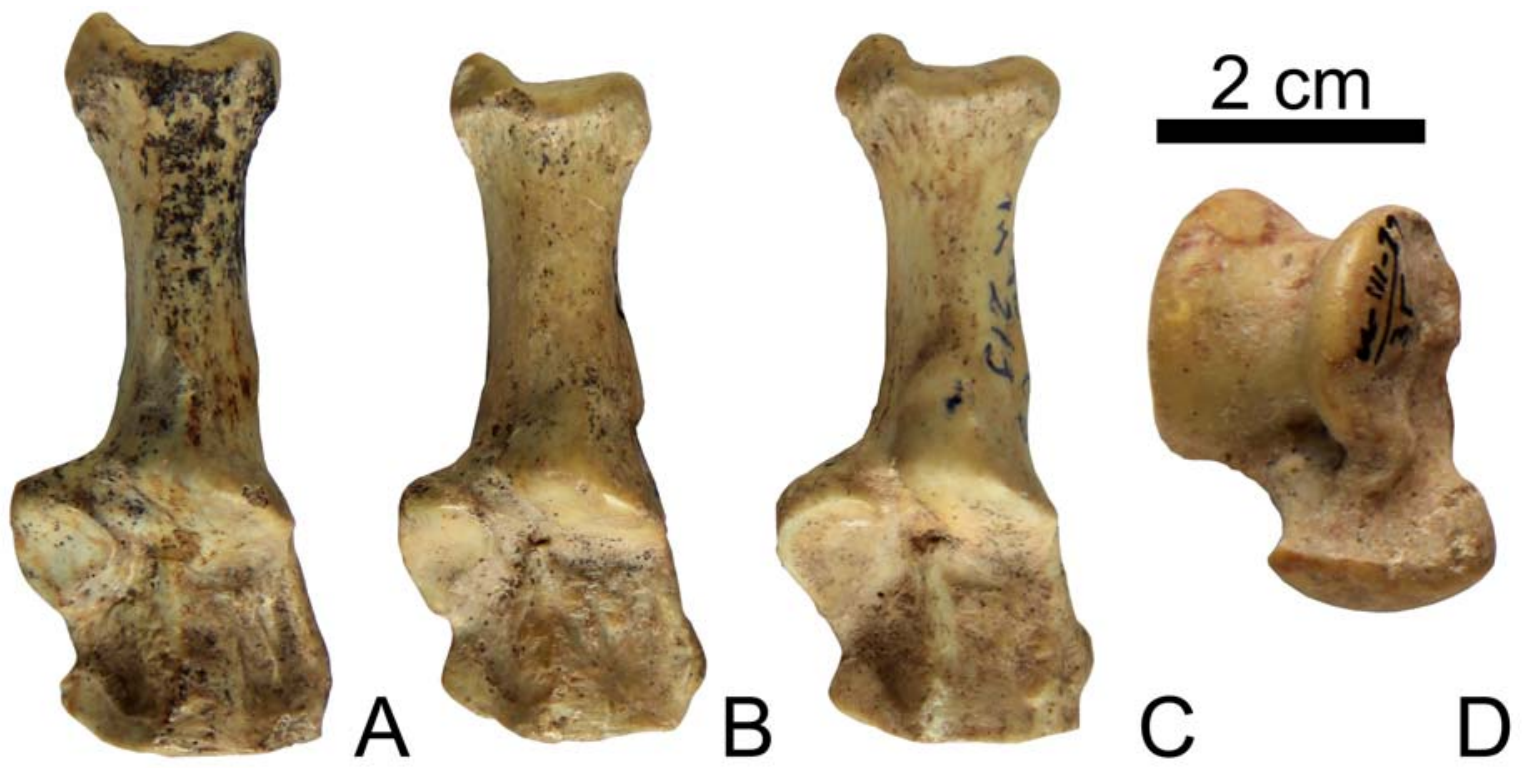

Figure 12. Left calcanei (A-C) and right talus (D) of Cuon alpinus caucasicus from Kudaro 3 Cave; dorsal views. A - ZIN 36672-2; B - ZIN 36701; C - ZIN 36671-1; D - ZIN 36693.

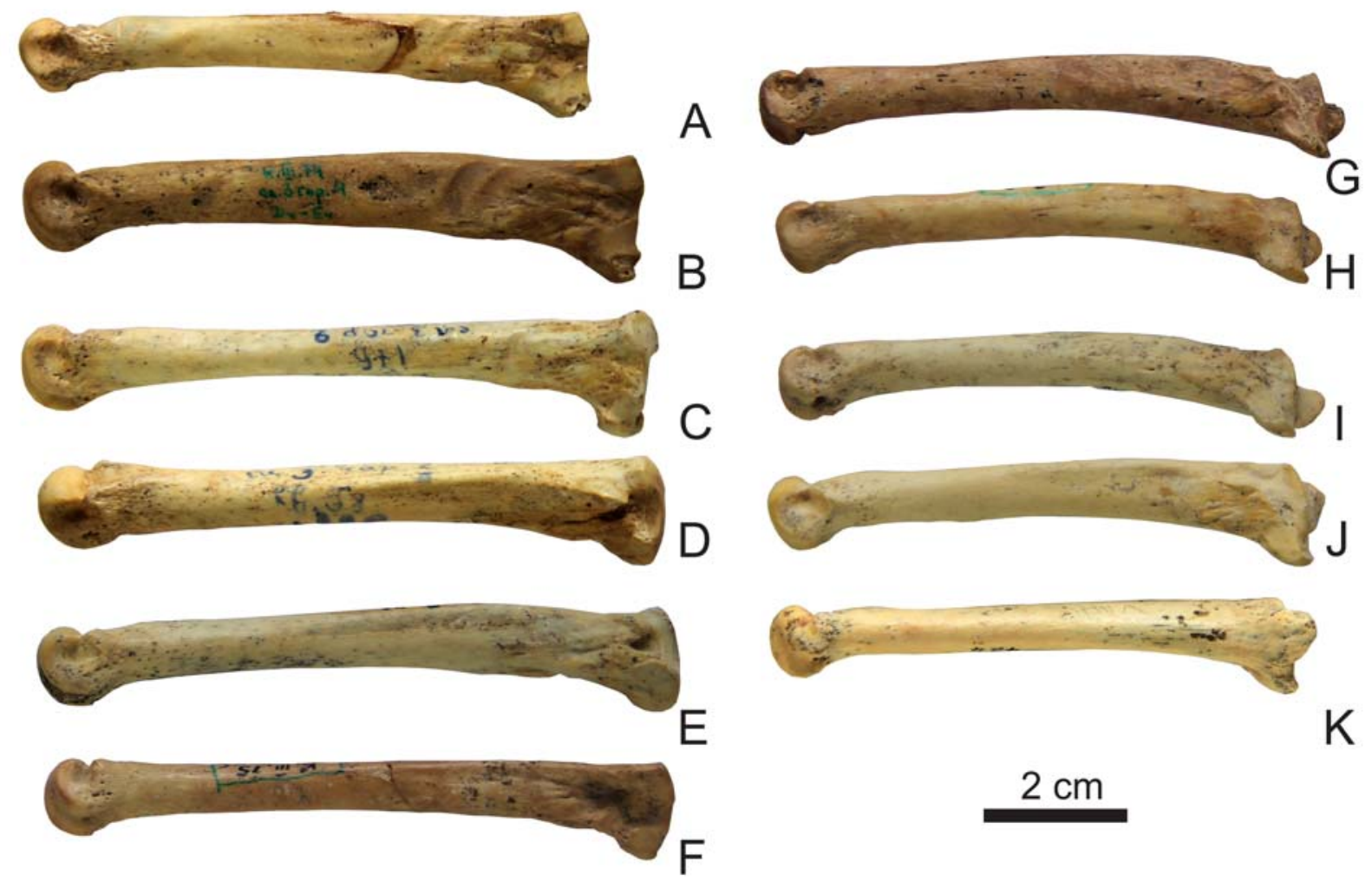

Figure 13. Left (A, B, F, K) and right (C, E, G-J) metatarsal bones of Cuon alpinus caucasicus from Kudaro 3 Cave; lateral $(\mathrm{L})$ and medial $(\mathrm{A}-\mathrm{J})$ views.

A — left Mt2, ZIN 36671-2; B — left Mt2, ZIN 36681-2; C — right Mt3, ZIN 36672-1; D — right Mt4, ZIN 36671-3; E — right Mt4, ZIN 36702-1; F — left Mt4, ZIN 36687; G-J — right Mt5 (G — ZIN 36707, H — ZIN — 36689-1, I — ZIN — 36690-1, J — ZIN 36705-2); K - left Mt5, ZIN 36705-5. 
Table 18. Measurements (in mm) of fore limb bones Cuon alpinus caucasicus.

\begin{tabular}{|c|c|c|c|c|c|c|c|c|c|c|c|c|c|c|}
\hline Bones & $\begin{array}{l}\text { Localities } \\
\text { and } \\
\text { museum } \\
\text { number } \\
\text { (ZIN) }\end{array}$ & GL & GB & $\mathrm{Bp}$ & $\mathrm{Dp}$ & SD & $\overline{\mathrm{Bd}}$ & $\mathrm{Dd}$ & SLC & GLP & BG & $\overline{D P A}$ & SDO & $\mathrm{BPC}$ \\
\hline \multirow{4}{*}{ Scapula } & $\begin{array}{c}\text { Kudaro } 3 \\
(36692-1)\end{array}$ & & & & & & & & 29.1 & 34.7 & 22.2 & & & \\
\hline & $\begin{array}{c}\text { Kudaro 3 } \\
(36696-3)\end{array}$ & & & & & & & & & 30.5 & 21.0 & & & \\
\hline & $\begin{array}{c}\text { Kudaro } 3 \\
(36708-4) \\
\end{array}$ & & & & & & & & 27.7 & 34.4 & 20.8 & & & \\
\hline & $\begin{array}{l}\text { Kudaro } 3 \\
(36705-3)\end{array}$ & & & & & & & & & 31.5 & 18.4 & & & \\
\hline \multirow{8}{*}{$\begin{array}{l}\text { Hume- } \\
\text { rus }\end{array}$} & $\begin{array}{c}\text { Kudaro 1 } \\
(36669)\end{array}$ & & & $\begin{array}{l}\text { ca. } \\
34\end{array}$ & 49.5 & & & & & & & & & \\
\hline & $\begin{array}{c}\text { Kudaro 1 } \\
(36667)\end{array}$ & & & & & 17.8 & & & & & & & & \\
\hline & $\begin{array}{c}\text { Kudaro 3 } \\
(36708-3)\end{array}$ & $\begin{array}{c}196 . \\
0\end{array}$ & & 34.6 & 50.7 & 15.1 & 37.3 & 30.0 & & & & & & \\
\hline & $\begin{array}{l}\text { Kudaro } 3 \\
(36708-1)\end{array}$ & $\begin{array}{c}198 . \\
0\end{array}$ & & 34.7 & 50.8 & 15.4 & 37.4 & 29.9 & & & & & & \\
\hline & $\begin{array}{l}\text { Kudaro } 3 \\
(36684-1)\end{array}$ & & & & & 16.3 & 35.9 & 28.6 & & & & & & \\
\hline & $\begin{array}{c}\text { Kudaro } 3 \\
(36674) \\
\end{array}$ & & & & & & 33.9 & 26.5 & & & & & & \\
\hline & $\begin{array}{c}\text { Kudaro } 3 \\
(31241-2) \\
\end{array}$ & & & 31.9 & 46.6 & & & & & & & & & \\
\hline & $\begin{array}{c}\text { Kudaro } 3 \\
(36679-1)\end{array}$ & & & & & 14.6 & 34.9 & 28.1 & & & & & & \\
\hline \multirow{8}{*}{ Ulna } & $\begin{array}{c}\text { Kudaro 1 } \\
(36733-1)\end{array}$ & & & & & & & & & & & & & 18.3 \\
\hline & $\begin{array}{c}\text { Kudaro 1 } \\
(36739)\end{array}$ & & & & & & & & & & & 32.2 & - & 17.2 \\
\hline & $\begin{array}{c}\text { Kudaro } 3 \\
(36698-1)\end{array}$ & & & & & & & & & & & 28.7 & 24.5 & 18.9 \\
\hline & $\begin{array}{l}\text { Kudaro 3 } \\
(36697-2)\end{array}$ & & & & & & & & & & & 34.0 & 29.5 & 21.5 \\
\hline & $\begin{array}{l}\text { Kudaro } 3 \\
(36677-2)\end{array}$ & & & & & & & & & & & 33.6 & 28.6 & 21.7 \\
\hline & $\begin{array}{c}\text { Kudaro } 3 \\
(31241-3) \\
\end{array}$ & & & & & & & & & & & 30.3 & 26.5 & 17.0 \\
\hline & $\begin{array}{c}\text { Kudaro } 3 \\
(36670)\end{array}$ & & & & & & & & & & & 28.8 & & 18.5 \\
\hline & $\begin{array}{c}\text { Kudaro } 3 \\
(36705-7)\end{array}$ & & & & & & & & & & & & & 15.0 \\
\hline \multirow{4}{*}{ Radius } & $\begin{array}{c}\text { Kudaro 3 } \\
(36698-2)\end{array}$ & & & & & 15.3 & 28.5 & 15.8 & & & & & & \\
\hline & $\begin{array}{c}\text { Kudaro } 3 \\
(31241-4)\end{array}$ & & & 20.3 & 13.5 & & 28.0 & 15.2 & & & & & & \\
\hline & $\begin{array}{c}\text { Kudaro } 3 \\
(36670-2)\end{array}$ & & & 20.5 & 13.6 & & & & & & & & & \\
\hline & $\begin{array}{c}\text { Kudaro } 3 \\
(36705-4)\end{array}$ & & & 20.3 & 13.2 & & & & & & & & & \\
\hline $\begin{array}{l}\text { Sca- } \\
\text { phoid }\end{array}$ & $\begin{array}{c}\text { Kudaro 1 } \\
(36664-2)\end{array}$ & & 24.9 & & & & & & & & & & & \\
\hline $\begin{array}{l}\text { Pisi- } \\
\text { form }\end{array}$ & $\begin{array}{c}\text { Kudaro } 3 \\
(36704)\end{array}$ & 22.0 & & & & & & & & & & & & \\
\hline \multirow{2}{*}{ Mc2 } & $\begin{array}{c}\text { Kudaro } 3 \\
(36702-4)\end{array}$ & 69.3 & & 10.2 & 13.8 & 8.6 & 11.7 & 9.8 & & & & & & \\
\hline & $\begin{array}{c}\text { Kudaro } 3 \\
(36681-1)\end{array}$ & 74.2 & & 10.9 & 15.2 & 9.4 & 13.4 & 12.6 & & & & & & \\
\hline
\end{tabular}


Table 18 (continued).

\begin{tabular}{|c|c|c|c|c|c|c|c|c|c|c|c|c|c|c|}
\hline Bones & $\begin{array}{c}\text { Localities } \\
\text { and } \\
\text { museum } \\
\text { number } \\
(\mathrm{ZIN})\end{array}$ & GL & GB & $\mathrm{Bp}$ & $\mathrm{Dp}$ & SD & $\overline{B d}$ & $\mathrm{Dd}$ & SLC & GLP & $\mathrm{BG}$ & DPA & SDO & BPC \\
\hline Mc3 & $\begin{array}{c}\text { Kudaro } 3 \\
(36673-3)\end{array}$ & & & 10.3 & 13.1 & 7.9 & & & & & & & & \\
\hline Mc4 & $\begin{array}{c}\text { Kudaro } 3 \\
(36698-4)\end{array}$ & 77.0 & & 8.7 & 12.5 & 7.7 & 10.6 & 10.9 & & & & & & \\
\hline \multirow{2}{*}{ Mc5 } & $\begin{array}{c}\text { Kudaro } 3 \\
(36684-2)\end{array}$ & 61.5 & & 13.6 & 12.7 & 8.5 & 12.2 & 10.5 & & & & & & \\
\hline & $\begin{array}{c}\text { Kudaro } 3 \\
(36692-3)\end{array}$ & 60.6 & & 11.9 & 12.6 & 8.6 & 11.9 & 10.5 & & & & & & \\
\hline
\end{tabular}

Table 19. Measurements (in mm) of hind limb bones Cuon alpinus caucasicus.

\begin{tabular}{|c|c|c|c|c|c|c|c|c|c|c|c|c|}
\hline Bones & $\begin{array}{l}\text { Localities and museum } \\
\text { number }\end{array}$ & GL & GB & $\mathrm{Bp}$ & $\mathrm{Dp}$ & $\mathrm{SD}$ & $\mathrm{Bd}$ & $\mathrm{Dd}$ & $\mathrm{DC}$ & LA & $\mathrm{SH}$ & SB \\
\hline \multirow{4}{*}{ Pelvis } & Kudaro 1 (ZIN 36668) & & & & & & & & & 23.2 & 20.8 & \\
\hline & Kudaro 3 (ZIN 31241-5) & & & & & & & & & 23.8 & 23.3 & 9.7 \\
\hline & Kudaro 3 (ZIN 36688-1) & & & & & & & & & 24.5 & & \\
\hline & Kudaro 3 (ZIN 36681-3) & & & & & & & & & & 24.2 & 10.6 \\
\hline \multirow{2}{*}{ Femur } & Kudaro 3 (ZIN 36692-2) & & & 48.7 & & & & & 22.7 & & & \\
\hline & Kudaro 3 (ZIN 36700-2) & & & & & 15.2 & & & 21.7 & & & \\
\hline Patella & Kudaro 3 (ZIN 36688-5) & 19.2 & 13.1 & & & & & & & & & \\
\hline \multirow{4}{*}{ Tibia } & Kudaro 1 (ZIN 36737-2) & & & & & & 24.8 & 17.6 & & & & \\
\hline & Kudaro 3 (ZIN 36708-2) & 217.6 & & & 47.1 & 15.9 & 27.8 & 19.4 & & & & \\
\hline & Kudaro 3 (ZIN 36702-3) & & & & & & 26.3 & 19.3 & & & & \\
\hline & Kudaro 3 (ZIN 36705-1) & & & & & & 28.2 & 19.6 & & & & \\
\hline \multirow{2}{*}{ Fibula } & Kudaro 3 (ZIN 36691-4) & & & & & & 16.0 & & & & & \\
\hline & Kudaro 3 (ZIN 36685-2) & & & & & & 13.9 & & & & & \\
\hline \multirow{6}{*}{$\begin{array}{l}\text { Calca- } \\
\text { neus }\end{array}$} & Kudaro 1 (ZIN 36730-1) & 51.1 & 20.8 & & & & & & & & & \\
\hline & Kudaro 3 (ZIN 36706-1) & 47.6 & 20.6 & & & & & & & & & \\
\hline & Kudaro 3 (ZIN 36672-2) & 53.7 & 22.5 & & & & & & & & & \\
\hline & Kudaro 3 (ZIN 36701) & 50.9 & 21.7 & & & & & & & & & \\
\hline & Kudaro 3 (ZIN 36671-1) & 52.4 & 22.8 & & & & & & & & & \\
\hline & Kudaro 3 (ZIN 36676-1) & & 23.2 & & & & & & & & & \\
\hline \multirow{5}{*}{ Talus } & Kudaro 3 (ZIN 36691-2) & 29.0 & 26.9 & & & & & & & & & \\
\hline & Kudaro 3 (ZIN 36694-1) & 31.9 & 29.4 & & & & & & & & & \\
\hline & Kudaro 3 (ZIN 36693) & 30.2 & 28.2 & & & & & & & & & \\
\hline & Kudaro 3 (ZIN 36680-5) & 31.5 & 29.4 & & & & & & & & & \\
\hline & Kudaro 3 (ZIN 36695-2) & 31.9 & 23.0 & & & & & & & & & \\
\hline \multirow{3}{*}{$\begin{array}{l}\text { Navi- } \\
\text { cular }\end{array}$} & Kudaro 3 (ZIN 36692-4) & 10.4 & 20.0 & & & & & & & & & \\
\hline & Kudaro 3 (ZIN 36691-3) & 10.8 & 20.9 & & & & & & & & & \\
\hline & Kudaro 3 (ZIN 36676-3) & 11.0 & 20.9 & & & & & & & & & \\
\hline \multirow{5}{*}{ Mt2 } & Kudaro 1 (36731-1) & & & 9.9 & - & 7.4 & & & & & & \\
\hline & Kudaro 3 (ZIN 36698-3) & & & 8.8 & 15.8 & 9.0 & & & & & & \\
\hline & Kudaro 3 (ZIN 36671-2) & 79.4 & & 9.7 & 14.6 & 8.7 & 13.2 & 10.7 & & & & \\
\hline & Kudaro 3 (ZIN 36681-2) & 86.0 & & 11.4 & 17.5 & 9.5 & 13.3 & 12.7 & & & & \\
\hline & Kudaro 3 (ZIN 36700-2) & 77.3 & & 9.4 & 15.5 & 8.1 & 11.9 & 10.4 & & & & \\
\hline \multirow{5}{*}{ Mt3 } & Kudaro 1 (ZIN 36663) & & & 11.9 & & & & & & & & \\
\hline & Kudaro 3 (ZIN 36685-1) & & & 12.2 & 17.4 & 9.3 & & & & & & \\
\hline & Kudaro 3 (ZIN 36672-1) & 89.4 & & 11.9 & 17.4 & 9.0 & 11.8 & 12.0 & & & & \\
\hline & Kudaro 3 (ZIN 36691-1) & & & 11.2 & & 8.8 & & & & & & \\
\hline & Kudaro 3 (ZIN 36676-2) & & & 12.2 & 17.5 & 9.2 & & & & & & \\
\hline
\end{tabular}


Table 19 (continued).

\begin{tabular}{|c|c|c|c|c|c|c|c|c|c|c|c|c|}
\hline Bones & $\begin{array}{c}\text { Localities and museum } \\
\text { number }\end{array}$ & GL & GB & $\mathrm{Bp}$ & $\mathrm{Dp}$ & SD & $\mathrm{Bd}$ & $\mathrm{Dd}$ & $\overline{\mathrm{DC}}$ & LA & $\mathrm{SH}$ & SB \\
\hline \multirow{7}{*}{ Mt4 } & Kudaro 1 (ZIN 36666) & & & 11.6 & 15.5 & & & & & & & \\
\hline & Kudaro 3 (ZIN 36702-1) & 87.4 & & 11.6 & 14.8 & 8.6 & 11.0 & 11.0 & & & & \\
\hline & Kudaro 3 (ZIN 36687) & 85.1 & & 10.3 & 13.5 & 7.9 & 10.1 & 10.8 & & & & \\
\hline & Kudaro 3 (ZIN 36684-3) & & & 10.9 & 14.9 & 8.6 & & & & & & \\
\hline & Kudaro 3 (ZIN 36671-3) & 87.4 & & 12.1 & 15.0 & 9.2 & 11.7 & 12.0 & & & & \\
\hline & Kudaro 3 (ZIN 36708-5) & & & 10.7 & 16.3 & 8.8 & & & & & & \\
\hline & Kudaro 3 (ZIN 36705-8) & 94.9 & & 11.5 & 16.1 & 8.5 & 12.0 & 12.3 & & & & \\
\hline \multirow{7}{*}{ Mt5 } & Kudaro 3 (ZIN 36682-4) & 76.7 & & 9.7 & 10.3 & 8.1 & 10.4 & 9.4 & & & & \\
\hline & Kudaro 3 (ZIN 36686) & & & 11.0 & 11.9 & 7.7 & & & & & & \\
\hline & Kudaro 3 (ZIN 36690-1) & 75.5 & & 11.9 & 13.1 & 7.8 & 11.3 & 10.1 & & & & \\
\hline & Kudaro 3 (ZIN 36707) & 81.6 & & 10.4 & 12.9 & 8.0 & 11.3 & 10.6 & & & & \\
\hline & Kudaro 3 (ZIN 36705-2) & 78.5 & & 11.6 & 14.3 & 8.4 & 11.7 & 10.5 & & & & \\
\hline & Kudaro 3 (ZIN 36705-5) & 75.7 & & 10.5 & 12.6 & 7.9 & 11.7 & 10.3 & & & & \\
\hline & Kudaro 3 (ZIN 36689-1) & 75.7 & & 11.7 & 13.0 & 7.4 & 11.0 & 10.1 & & & & \\
\hline
\end{tabular}

Discussion. Fossil remains of $C$. alpinus are widespread in Upper Pleistocene layers 3-4 of both Kudaro caves; this species may comprise several earlier fragmentary fossils from layer 5 of Kudaro 3 Cave. The lower portion of layer 4 yielded fewer finds of dhole bones in comparison with layer 3 , when these caves were situated, judging from the palynological data, at the upper border of forest belt (Lioubine, 1989).

The Pleistocene representatives of $C$. alpinus were larger than the recent animals, being heavier, stronger and hardier predators. Presumably, similar to recent Caucasian dholes, they lived in packs, migrating great distances. The abundance and variety of bone fragments, including several vertebrae arranged in anatomical order, suggest burial of the complete carcasses or their large fragments in the Kudaro caves. Most probably, these burials took place at the time of seasonal migrations of dholes to the upper belt of mountain forest and alpine meadows.

In the Caucasus, lower carnassial teeth of $C$. alpinus have been also found in Tsona Cave in Georgia (Vekua et al., 1987) and in Matuzka Cave in the Northern Caucasus (Baryshnikov, Golovanova, 1989). The specimen from Tsona Cave shows a reduced metaconid; nevertheless, the tooth dimensions $(\mathrm{L}=22.1 \mathrm{~mm}, \mathrm{~W}=9.0$ $\mathrm{mm}$ ) are typical of C. a. caucasus. Two fragmented teeth $\mathrm{m} 1$ from Matuzka Cave are noticeably smaller and exhibit shape characteristic for the recent $C$. alpinus.

C. alpinus is regarded as the descendant of $C$. priscus from the Middle Pleistocene of Europe (Fontana Ranuccio F.U. in Italy, near $0.5 \mathrm{Ma}$; Brugal \& BoudadiMaligne, 2011; Petronio et al., 2011), which inhabited Eurasia and, via Beringia, came to North America, reaching the northeastern part of Mexico (San Josecito Cave) (Tedford et al., 2009).

As a result of cladistic analysis, Cuon was combined in a single cluster with the recent genus Lycaon and with the extinct genus Xenocyon (Tedford et al., 2009). Molecular analyses also affiliate Cuon alpinus with Lycaon pictus (Temminck, 1820), placing these species together with wolves, coyotes, and jackals in a group of wolf-like canids (Zravý \& Řičánková, 2004; Bardeleben et al., 2005). Tropical populations of $C$. alpinus from the Asian mainland comprise two major phylogeographical groupings (Iyengar et al., 2005).

Genus Vulpes Frisch, 1775

$\dagger$ Vulpes praeglacialis (Kormos, 1932)

Referred specimens. Middle Pleistocene, Kudaro 1 Cave: right $\mathrm{m} 2$ (ZIN 36600-2, layer 5, horizon 9, 1958), distal fragment of right humerus (ZIN 36598-1, layer 5, horizon 5, 1959), proximal fragment of right ulna (ZIN 36600-1, layer 5, horizon 9, 1958), fragment of right radius (ZIN 36599, layer 5, horizon 6, 1958), fragment of left metacarpal 4 (ZIN 36600-3, layer 5, horizon 9, 1958), left calcaneus (ZIN 36598-2, layer 5, horizon 5, 1959); total 6 remains.

Description. The lower molar m2 (ZIN 36600-2) of a small fox from the lower part of layer $5 \mathrm{c}$ is markedly smaller in length and width than the specimens of this tooth of the red fox $V$. vulpes found in Kudaro caves. The length of ZIN 36600-2 is smaller than the mean value of this dimension calculated for the sample of the recent $V$. vulpes (L., 1758) from the Caucasus, whereas the width of the fossil tooth is located within the area of minimum width parameters of $\mathrm{m} 2$ for the recent sample. At the same time, ZIN 36600-2 shows no size difference with this tooth of $V$. praeglacialis from the Early and Middle Pleistocene of Europe (Tab. 20).

Layer $5 \mathrm{c}$ was found to contain several bone fragments of small-fox limbs. The humerus (ZIN 36598-1) corresponds in width of the distal epiphysis $(\mathrm{Bd}=18.5$ $\mathrm{mm}$ ) to that of recent arctic fox $V$. lagopus (L., 1758) and $V$. praeglacialis from grotto l'Escale in France (Bonifay, 1971).

The ulna fragment (ZIN 36600-1), in the dimensions of the olecranon $(\mathrm{SDO}=11.4 \mathrm{~mm}, \mathrm{DPA}=13.3$ $\mathrm{mm}$ ), is similar to the ulna of $V$. lagopus and corsak fox, $V$. corsak (L., 1768). Unlike the fossil $V$. vulpes from Kudaro 1, in $V$. lagopus the upper margin of olecranon is not elevated posteriorly and forms, thus, nearly a 
Table 20. Measurements (in $\mathrm{mm}$ ) of lower molar $\mathrm{m} 2$ in Pleistocene Vulpes.

\begin{tabular}{|c|c|c|c|}
\hline Species & Locality and reference & $\mathrm{L}$ & $\mathrm{W}$ \\
\hline \multirow{15}{*}{$\begin{array}{l}\text { V.prae- } \\
\text { glacialis }\end{array}$} & $\begin{array}{l}\text { Kudaro 1, layer } 5 \text { (ZIN } \\
36600-2)\end{array}$ & 6.5 & 4.8 \\
\hline & Kalkberg (Kormos, 1932) & 5.6 & 4.4 \\
\hline & Brassó (Kormos, 1932) & 6.3 & 4.3 \\
\hline & \multirow{9}{*}{ l'Escale (Bonifay, 1971) } & 6.4 & 4.8 \\
\hline & & 6.8 & 5.1 \\
\hline & & 6.8 & 4.9 \\
\hline & & 6.0 & 4.9 \\
\hline & & 6.4 & 4.2 \\
\hline & & 6.1 & 4.8 \\
\hline & & 6.5 & 4.6 \\
\hline & & 5.0 & 4.1 \\
\hline & & 5.1 & 4.3 \\
\hline & Stránská skála (Musil, 1972) & 5.9 & 4.2 \\
\hline & Hundsheim (Thenius, 1954) & 7.1 & 4.5 \\
\hline & $\begin{array}{l}\text { Cal Guardiola (Madurell- } \\
\text { Malapeira et al., 2009) }\end{array}$ & 6.6 & 4.9 \\
\hline \multirow{12}{*}{ V. vulpes } & \multirow{2}{*}{ Kudaro 1, layer 5} & 7.2 & 5.8 \\
\hline & & 7.2 & 5.4 \\
\hline & \multirow{4}{*}{ Kudaro 3, layers 3-4 } & 6.8 & 5.5 \\
\hline & & 6.7 & 4.8 \\
\hline & & 7.6 & 5.2 \\
\hline & & 6.9 & 5.7 \\
\hline & \multirow{6}{*}{ l'Escale (Bonifay, 1971) } & 7.1 & 5.4 \\
\hline & & 6.5 & 5.0 \\
\hline & & 7.6 & 5.6 \\
\hline & & 7.7 & 5.4 \\
\hline & & 8.8 & 6.4 \\
\hline & & 8.5 & 5.5 \\
\hline
\end{tabular}

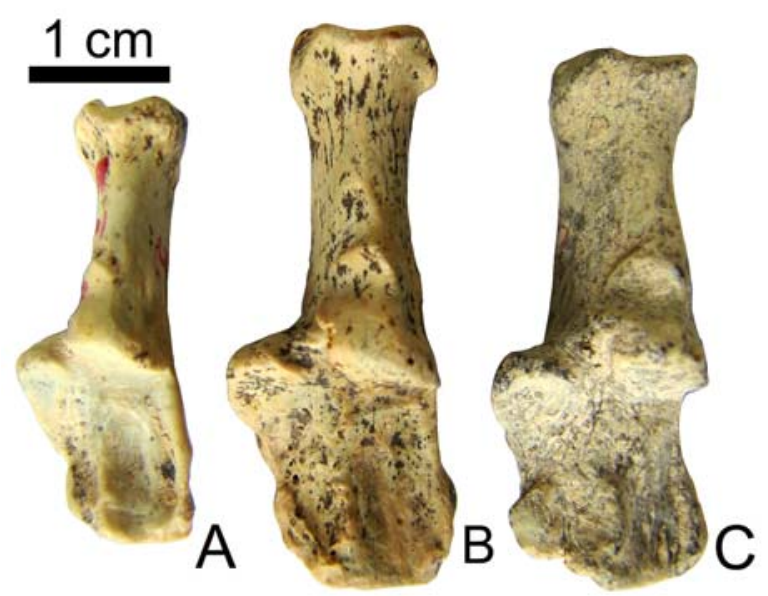

Figure 14. Left calcanei of Pleistocene foxes Vulpes praeglacialis (A) and $V$. vulpes $(\mathrm{B}, \mathrm{C})$ from Kudaro 1 Caves; dorsal views.

A - ZIN 36598-2; B — ZIN 36542-1; C - ZIN 36529-1.

right angle with the posterior (palmar) margin of this bone.

The proximal fragment of a radius (ZIN 36599), with measurements $(\mathrm{Bp}=9.4 \mathrm{~mm}, \mathrm{Bd}=5.8 \mathrm{~mm})$, is noticeably smaller than this bone in $V$. vulpes and resembles $V$. lagopus.
The fragment of a metacarpal 4 (ZIN 36600-3) is similar in size $(\mathrm{SD}=3.2 \mathrm{~mm}, \mathrm{Bd}=4.3 \mathrm{~mm}, \mathrm{Dd}=5.6 \mathrm{~mm})$ to $\mathrm{Mc} 4$ of the recent $V$. lagopus.

The calcaneus (ZIN 36598-2; Fig. 14A) from layer 5 is markedly smaller $(\mathrm{GL}=28.0 \mathrm{~mm}, \mathrm{~GB}=10.8 \mathrm{~mm})$ in comparison with this bone in $V$. vulpes from Kudaro caves (Fig. 14B, C), revealing similarity in length and width with that of $V$. praeglacialis from grotto l'Escale (Bonifay, 1971). It is larger and more robust than the same bone in $V$. corsak and raccoon dog Nyctereutes procyonoides (Gray, 1834), both latter species having a calcaneus, as a rule, shorter than $27 \mathrm{~mm}$. In addition, the fossil bone differs from the calcaneus of $N$. procyonoides in the development of a longitudinal ridge on the dorsal wall of bone distal part, which is absent in the raccoon dog. By its size, ZIN 36598-2 corresponds to the calcaneus of $V$. lagopus; however, the distal part (below coracoid facet) of the fossil specimens is longer. The length of distal part constitutes $55.7 \%$ of the length of proximal part; at the same time, this ratio does not exceed $52 \%$ in $V$. lagopus. The correlation between the length of the distal part and maximum width of calcaneus is calculated as $94.5 \%$, being less than $90 \%$ in $V$. lagopus. These indices link the fossil bone with that of the recent $V$. vulpes (Gromova, 1960).

Discussion. Isolated remains of a small fox found in the lower part of layer 5 in Kudaro 1 Cave reveal a metric resemblance to $V$. praeglacialis and indicate, for the first time, the presence of this species in Caucasus. These fox remains are also similar in size to the recent $V$. lagopus, differing from the latter by several morphological characters.

The earliest fossil foxes are recorded in Europe in the middle Villafranchian (Les Etouaires, Villaroya, Saint-Vallier, Val d'Arno, Varshets, Dafnero 1) with $V$. alopecoides Forsyth Major (biochron MN16b-18; Bonifay, 1971; Spassov, 2003; Argant, 2004; Palombo \& Vialli, 2004). Later, it was replaced by $V$. praeglacialis resembling in size the recent polar fox, but differing from it in the details of structure of the cheek teeth, including a larger $\mathrm{m} 2$ (Kormos, 1932). The species has been found in numerous European localities of the Early Pleistocene (Venta Micena, Cal Guardiola, Fuente Nueva-3, Barranco León, Quibas, Kalkberg, Beremend, Püspökfürdö, Brassó, Stránská skála 1) and Middle Pleistocene (l'Escale, Vergranne, Hundsheim, Heppenloch, Achenheim, Petralona) (biochron MNQ2023b; Kormos, 1932; Thenius, 1954; Bonifay, 1971, 1983; Kurtén \& Poulianos, 1977, 1981; Martínez-Navarro et al., 2003; Palombo \& Vialli, 2004; Calero et al., 2006; Madurell-Malapeira et al., 2009).

\section{Vulpes vulpes (Linnaeus, 1758)}

Referred specimens. Middle Pleistocene, Kudaro 1 Cave: upper cheek teeth (ZIN 36485, 36486), fragment of left mandible with m1-m2 (ZIN 36497, layer 5, horizon 5, 1958), lower cheek teeth (ZIN 36487, 36496-2, 36503-36506); Kudaro 3 Cave: upper cheek teeth (ZIN 36518-1), lower cheek teeth (ZIN 36518-2, 36593-11). 


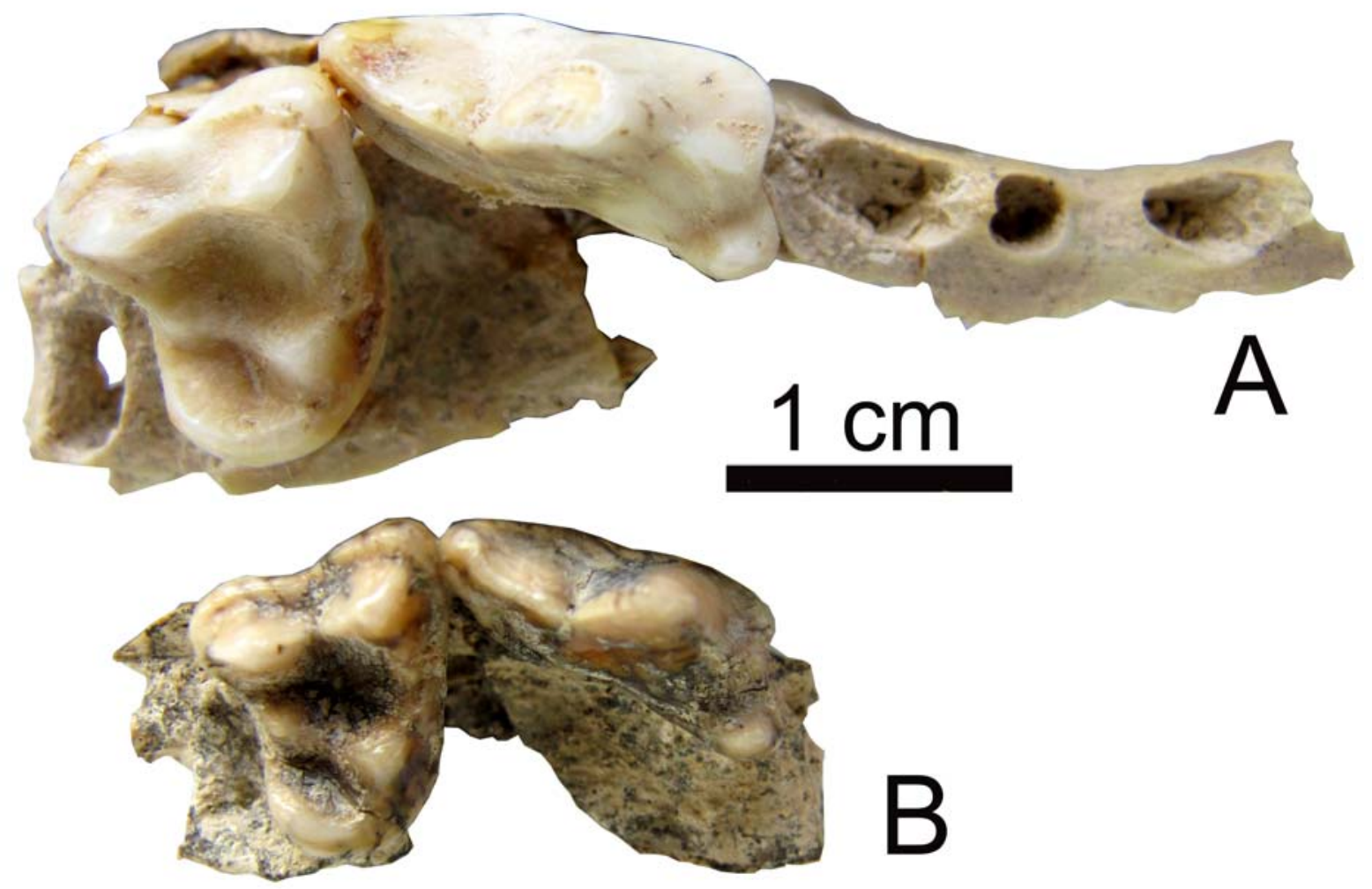

Figure 15. Maxilla fragments with P4-M1 of Vulpes vulpes from Kudaro 3 (A) and Kudaro 1 (B); occlusal view. A - ZIN 36492; B - ZIN 36488.

Late Pleistocene, Kudaro 1 Cave: fragment of right maxilla with P4-M1 (ZIN 36488, layer 4, 1961), upper cheek teeth (ZIN 36484-1, 36489-3), fragment of left mandible with p3-p4 (ZIN 36495, layer 3c, 1958), fragment of left mandible with p3def-p4 (ZIN 36493, layer 3, 1957), fragment of left mandible with $\mathrm{p} 1-\mathrm{m} 1$ (ZIN 36501, layer X-3, 1980), fragment of right mandible (ZIN 36499-1, layer 4, 1961), fragment of right mandible with p2 (ZIN 36500-1, mixed layers, 1961), fragment of left mandible with p4 (ZIN 36502-1, layer X-1, horizon 4, 1980), lower cheek teeth (ZIN 36494-2, 36498-3,4, 26503, 36507); Kudaro 3 Cave: fragment of left maxilla with P4-M1 (ZIN 36490, layer 3c, horizon $1,1977)$, fragment of right maxilla with P4-M2 (ZIN 36492, layer 3e, horizon 1, 1978), upper cheek teeth (ZIN 36489-3, 36491-3, 36584-2), fragment of left mandible (ZIN 36491-1, layer 3e, horizon 1, 1977), fragment of left mandible with p2 and $\mathrm{m} 2$ (ZIN 36508, layer 3, horizon 3, 1959), fragment of left mandible with p4 and m2 (ZIN 36509, layer 4, 1959), fragment of left mandible with p3-p4 (ZIN 36510-1, layer 3, horizon 4, 1974), fragment of right mandible with p2 and p4 (ZIN 36511, layer 4, horizon 5, 1975), fragment of right mandible with p2-m2 (ZIN 36517, mixed layers, 1979), fragment of right mandible with $m 2$ (ZIN $36512-$ 1 , layer 4 , horizon 3,1975$)$, lower cheek teeth (ZIN 36513-36516).
All layers of both caves also are found to contain isolated canines $(\sim 60)$, large fragments of limb bones $(>70)$, and portions of vertebrae, phalanges, and small bone fragments. A total of approximately 365 fossil remains have been collected.

Description. Numerous fossil remains of $V$. vulpes are represented in both Kudaro caves, primarily by fragmented bones and isolated teeth, which complicate the description of Pleistocene Caucasian red fox.

Fossil maxillary fragments (ZIN 36488, 36492; Fig. 15) exhibit no difference in the shape as well as in the length of the tooth row P4-M1 $(21.2 \mathrm{~mm}$ and $21.6 \mathrm{~mm}$, respectively) with maxillae of recent $V$. vulpes. In the fossil specimens, the protocone of $\mathrm{P} 4$ is markedly shifted forward, extending beyond the level of the anterior margin of the paracone; the metastyle blade is short (Fig. 16).

The recent Caucasian fauna includes three subspecies of red fox (V. v. caucasica Dinnik, 1914, V. v. alpherakyi Satunin, 1906 and V. v. alticola Ognev, 1926) (Aristov \& Baryshnikov, 2001). The red fox from Kudaro caves resembles, with respect to the mean value of the length of upper teeth $\mathrm{P} 4$ and M1, $V . v$. alticola, which is found in the Lesser Caucasus and in the Armenian Highland; however, the latter subspecies is characterized by significantly wider teeth (Tab. 21).

The available mandible fragments from Kudaro caves suggest a rather small size for fossil $V$. vulpes 
Table 21. Measurements (in $\mathrm{mm}$ ) of upper cheek teeth in Pleistocene and recent Vulpes vulpes from Caucasus.

\begin{tabular}{|c|c|c|c|c|c|}
\hline \multirow{2}{*}{\multicolumn{2}{|c|}{ Measurements }} & \multirow{3}{*}{$\begin{array}{c}\text { Middle and Late Pleistocene } \\
\text { Kudaro } 1 \text { and Kudaro } 3 \\
2\end{array}$} & \multicolumn{3}{|c|}{ Recent subspecies (males and females) } \\
\hline & & & \multirow{2}{*}{$\frac{V . v \cdot \text { caucasica }}{22}$} & \multirow{2}{*}{$\frac{V . v . \text { alpherakyi }}{5}$} & \multirow{2}{*}{$\frac{V . v \cdot \text { alticola }}{14}$} \\
\hline \multirow{4}{*}{$\mathrm{P} 2, \mathrm{~L}$} & $n$ & & & & \\
\hline & $\lim$ & $7.8,7.9$ & $7.5-9.4$ & $7.6-8.9$ & $7.7-9.5$ \\
\hline & mean & - & 8.58 & 8.12 & 8.45 \\
\hline & SD & - & 0.47 & 0.65 & 0.51 \\
\hline \multirow{4}{*}{$\mathrm{P} 2, \mathrm{~W}$} & $n$ & 2 & 22 & 5 & 14 \\
\hline & $\lim$ & $2.9,2.9$ & $2.6-3.4$ & $2.7-3.0$ & $2.6-4.3$ \\
\hline & mean & - & 3.04 & 2.90 & 3.05 \\
\hline & SD & - & 0.21 & 0.12 & 0.41 \\
\hline \multirow{4}{*}{ P3, L } & $n$ & 5 & 23 & 6 & 14 \\
\hline & $\lim$ & $8.5-9.5$ & $8.4-9.9$ & $8.3-9.2$ & $8.1-9.7$ \\
\hline & mean & 9.11 & 9.22 & 8.77 & 8.99 \\
\hline & SD & 0.44 & 0.42 & 0.39 & 0.51 \\
\hline \multirow{4}{*}{ P3, W } & $n$ & 5 & 23 & 6 & 14 \\
\hline & $\lim$ & $3.1-4.0$ & $2.8-4.1$ & $3.2-3.5$ & $2.9-3.7$ \\
\hline & mean & 3.49 & 3.31 & 3.38 & 3.27 \\
\hline & SD & 0.44 & 0.32 & 0.14 & 0.26 \\
\hline \multirow{4}{*}{$\begin{array}{l}\text { P4, total } \\
\text { length* }\end{array}$} & $n$ & 8 & 23 & 6 & 14 \\
\hline & $\lim$ & $13.4-14.9$ & $13.1-15.8$ & $12.8-14.4$ & $13.3-15.8$ \\
\hline & mean & 14.37 & 14.77 & 13.69 & 14.36 \\
\hline & SD & 0.53 & 0.66 & 0.52 & 0.70 \\
\hline \multirow{4}{*}{ P4, L } & $n$ & 9 & & & \\
\hline & $\lim$ & $13.0-14.3$ & & & \\
\hline & mean & 13.40 & & & \\
\hline & SD & 0.41 & & & \\
\hline \multirow{4}{*}{ P4, Lpa } & $n$ & 9 & 23 & 6 & 14 \\
\hline & $\lim$ & $7.9-8.8$ & $7.7-9.1$ & $6.7-8.5$ & $7.3-8.7$ \\
\hline & mean & 8.33 & 8.31 & 7.62 & 8.08 \\
\hline & SD & 0.24 & 0.42 & 0.65 & 0.47 \\
\hline \multirow{4}{*}{$\mathrm{P} 4, \mathrm{~W}$} & $n$ & 8 & 23 & 6 & 14 \\
\hline & $\lim$ & $5.8-6.7$ & $5.4-7.5$ & $5.2-6.6$ & $6.0-7.6$ \\
\hline & mean & 6.34 & 6.55 & 5.90 & 6.60 \\
\hline & SD & 0.34 & 0.51 & 0.48 & 0.48 \\
\hline \multirow{4}{*}{ M1, L } & $n$ & 4 & 23 & 6 & 14 \\
\hline & $\lim$ & $9.1-9.8$ & $8.3-10.2$ & $8.5-9.6$ & $8.8-10.0$ \\
\hline & mean & 9.50 & 9.26 & 9.12 & 9.51 \\
\hline & SD & 0.32 & 0.49 & 0.49 & 0.42 \\
\hline \multirow{4}{*}{ M1, Lpa } & $n$ & 4 & 23 & 6 & 14 \\
\hline & $\lim$ & $4.4-5.0$ & $4.3-5.7$ & $4.4-5.3$ & $4.6-5.5$ \\
\hline & mean & 4.74 & 4.97 & 4.74 & 5.04 \\
\hline & SD & 0.23 & 0.37 & 0.33 & 0.28 \\
\hline \multirow{4}{*}{ M1, W } & $n$ & 4 & 23 & 6 & 14 \\
\hline & $\lim$ & $10.9-11.8$ & $10.2-12.1$ & $10.4-11.4$ & $10.4-12.9$ \\
\hline & mean & 11.34 & 11.23 & 10.93 & 11.51 \\
\hline & SD & 0.41 & 0.56 & 0.42 & 0.67 \\
\hline \multirow{4}{*}{$\mathrm{M} 2, \mathrm{~L}$} & $n$ & 1 & 23 & 6 & 14 \\
\hline & $\lim$ & 5.1 & $4.4-8.0$ & $4.6-55$ & $4.4-6.0$ \\
\hline & mean & - & 5.34 & 5.12 & 5.22 \\
\hline & SD & - & 0.67 & 0.35 & 0.53 \\
\hline \multirow{4}{*}{$\mathrm{M} 2, \mathrm{~W}$} & $n$ & 1 & 23 & 6 & 14 \\
\hline & $\lim$ & 7.6 & $6.7-9.0$ & $7.3-8.7$ & $7.5-10.0$ \\
\hline & mean & - & 7.96 & 8.05 & 8.54 \\
\hline & SD & - & 0.59 & 0.55 & 0.69 \\
\hline
\end{tabular}

* Distances between protocon and posterior end of tooth. 


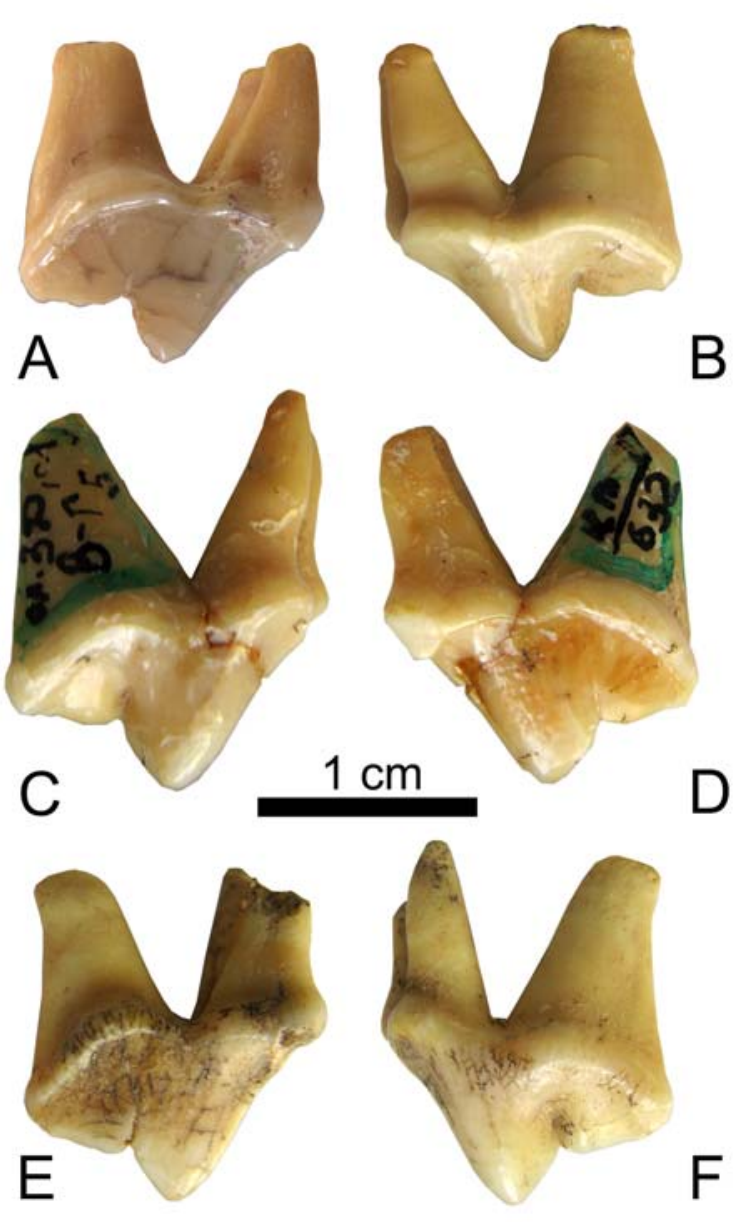

Figure 16. Upper carnassial tooth $\mathrm{P} 4$ of Vulpes vulpes from Kudaro 1 (A, B) and Kudaro 3 (C-F); labial (B, D, E, H, J, $\mathrm{K})$ and lingual (A, C, F, G, I, L) views.

A, B - ZIN 36486; C, D - ZIN 36491-3; E, F - ZIN 36489-3.

(Tab. 22). The length of p1-m1 (46.9-50.1 mm, $n=3)$ falls into the range of variation for this measurement in modern red fox from the Caucasus $(42.7-55.0 \mathrm{~mm}$, $n=40$ ). The shape of the mandibles and development of the posterior additional cusp on p3-p4 also corresponds to the modern species (Fig. 17).

With respect to the length of the premolar $\mathrm{p} 4$ and the length of the molar m2, the red fox from Kudaro caves resembles $V$. v. alticola, although the lower carnassial tooth $\mathrm{m} 1$ is longer and comparatively narrower in the fossil collection (Tab. 23).

The length of upper cheek teeth P4 and M1 and the length of the lower carnassial tooth $\mathrm{m} 1$ of red fox from Kudaro caves are similar to those in the fossil subspecies $V$. vulpes jansoni Bonifay from grotte de l'Escale in France (Bonifay, 1971).

Szuma (2004), examining morphological variability of the occlusal surface of the talonid in $\mathrm{m} 1$ of $V$. vulpes in the Holarctic, identified in recent red fox from the Caucasus the presence of morphotypes "P1", "P3" and "P4", the last being present nearly in half of the studied specimens $(n=27)$. The Kudaro collection (Fig. 18) revealed morphotypes "P1" (2 specimens), "P2" (1), "P3" (3), and "P4" (5), which show that the frequency of occurrence of the morphotypes in the fossil sample is similar to that in the recent Caucasian $V$. vulpes. Therefore, the dental characters of the red fox are highly conservative and reveal minimal change throughout time. In recent $V$. vulpes, the geographical variation of morphotype char-

Table 22. Measurements (in mm) of mandibles of Pleistocene Vulpes vulpes.

\begin{tabular}{|c|c|c|c|c|c|c|c|}
\hline \multirow[t]{3}{*}{ Measurements } & \multicolumn{2}{|c|}{ Kudaro 1} & \multirow{2}{*}{\multicolumn{4}{|c|}{$\begin{array}{c}\text { Kudaro } 3 \\
\text { Layers 3-4 }\end{array}$}} & \multirow{3}{*}{$\begin{array}{c}\text { Petralona, } \\
\text { Greece }\end{array}$} \\
\hline & \multirow{2}{*}{$\begin{array}{c}\text { Layer } 5 \\
\text { ZIN } 36497\end{array}$} & \multirow{2}{*}{$\begin{array}{l}\text { Layers 3-4 } \\
\text { ZIN 36501 }\end{array}$} & & & & & \\
\hline & & & $\begin{array}{c}\text { ZIN } \\
36511\end{array}$ & $\begin{array}{c}\text { ZIN } \\
36508\end{array}$ & $\begin{array}{c}\text { ZIN } \\
36491-1\end{array}$ & ZIN 36517 & \\
\hline Length $\mathrm{p} 1-\mathrm{m} 3$ & & 52.3 & & 61.4 & & 59.3 & \\
\hline Length p1-p4 & & 37.1 & 32.5 & & 34.8 & 34.1 & \\
\hline Length $\mathrm{m} 1-\mathrm{m} 3$ & & & & 27.4 & & 26.4 & 23.7 \\
\hline Length $\mathrm{m} 1-\mathrm{m} 2$ & 23.3 & & & & & & \\
\hline $\begin{array}{l}\text { Height behind } \\
\text { m1 }\end{array}$ & 15.8 & & 13.4 & & & & \\
\hline & & & & & & & \\
\hline p1 L & & 3.65 & & & 3.9 & & \\
\hline $\mathrm{W}$ & & 2.25 & & & 2.8 & & \\
\hline p2 L & & 8.65 & 8.4 & 8.55 & 9.3 & 8.9 & \\
\hline W & & 3.0 & 3.3 & 3.3 & 3.3 & 3.4 & \\
\hline p3 L & & 8.95 & & & 10.0 & 9.4 & \\
\hline $\mathrm{W}$ & & 3.1 & & & 3.4 & 3.4 & \\
\hline p4 L & & 8.95 & 9.1 & & 10.0 & & 8.5 \\
\hline $\mathrm{W}$ & & 3.8 & 4.0 & & 4.0 & & 3.8 \\
\hline $\mathrm{m} 1 \mathrm{~L}$ & 15.3 & 15.0 & & & & 16.05 & 14.2 \\
\hline $\mathrm{W}$ & 6.5 & 6.0 & & & & 6.15 & 5.7 \\
\hline $\mathrm{m} 2 \mathrm{~L}$ & 7.2 & & & 7.65 & & 6.95 & 6.5 \\
\hline W & ca. 5.8 & & & 5.2 & & 5.75 & 5.3 \\
\hline
\end{tabular}



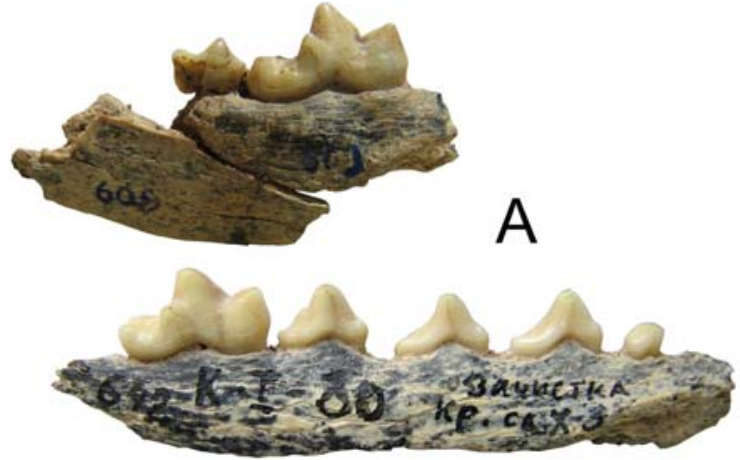

C

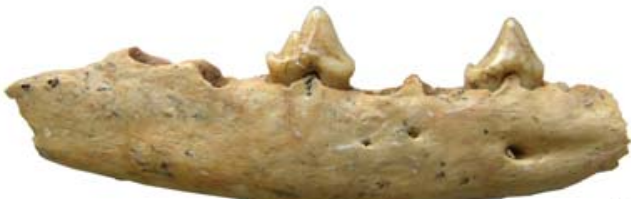

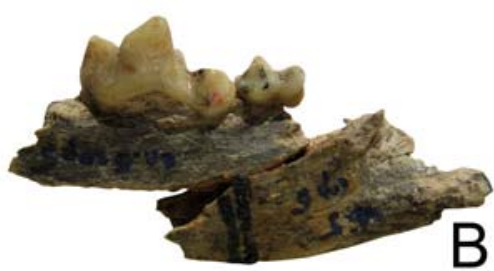

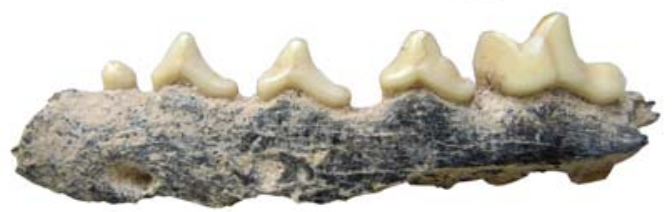

D
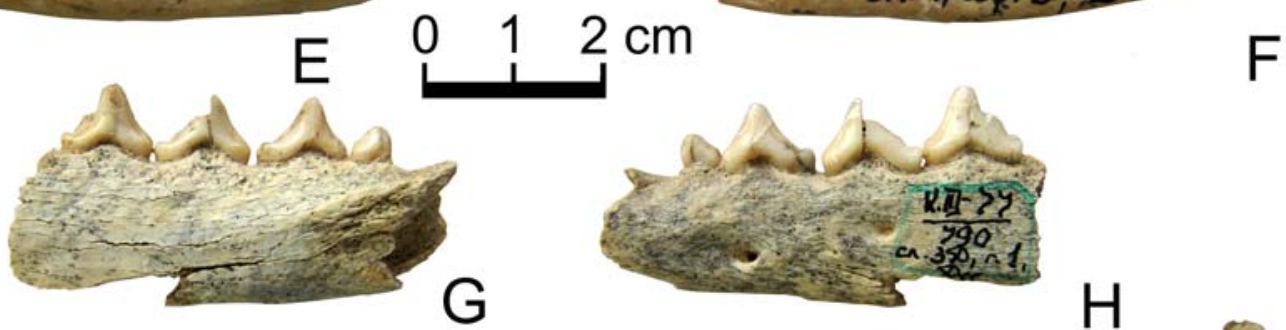

$\mathrm{H}$
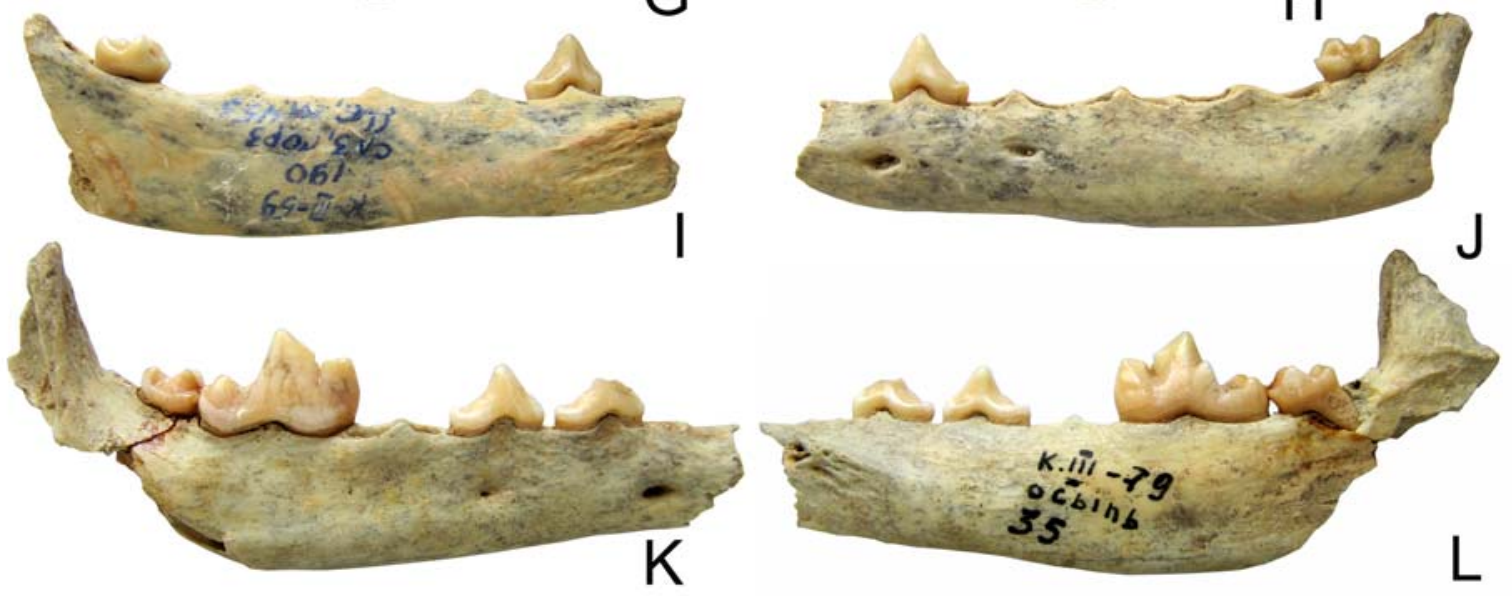

Figure 17. Fragments of mandibles of Vulpes vulpes from Kudaro 1 (A-D) and Kudaro 3 (E-L); labial (B, D, E, H, J, K) and lingual (A, C, F, G, I, L) views.

A, B - ZIN 36497; C, D - ZIN 36501; E, F - ZIN 36511; G, H - ZIN 36491-1; I, J - ZIN 36508; K, L — ZIN 36517.

acters is found to correspond to changes in geo-climatic factors (Szuma, 2007, 2008).

The male red fox is somewhat larger than the female, which is indicated by the size of the upper and lower canines (Fig. 19). The frequency distribution of the width of the upper canine in the Kudaro sample reveals that males and females are almost equally represented, whereas frequency distribution of the width of lower canine suggests predominance of females.
The dimensions of the limb bones reveal that the size of the fossil specimens only slightly exceeds that of recent red fox from the Caucasus (Tab. 24).

Therefore, no marked difference was found between fossil $V$. vulpes from Kudaro and the modern Caucasian representatives of this species. In addition, I failed to find reliable metric differences between Middle and Late Pleistocene red fox. 
Table 23. Measurements (in $\mathrm{mm}$ ) of lower cheek teeth in Pleistocene and recent Vulpes vulpes from Caucasus.

\begin{tabular}{|c|c|c|c|c|c|}
\hline \multirow{2}{*}{\multicolumn{2}{|c|}{ Measurements }} & \multirow{3}{*}{$\begin{array}{c}\text { Middle and Late Pleistocene } \\
\text { Kudaro } 1 \text { and Kudaro } 3 \\
4 \\
\end{array}$} & \multicolumn{3}{|c|}{ Recent subspecies (males and females) } \\
\hline & & & \multirow{2}{*}{$\frac{V . v \cdot \text { caucasica }}{20}$} & \multirow{2}{*}{$\frac{V . v \cdot \text { alpheraki }}{5}$} & \multirow{2}{*}{$\frac{V . v \cdot \text { alticola }}{12}$} \\
\hline \multirow{4}{*}{$\mathrm{p} 1, \mathrm{~L}$} & $n$ & & & & \\
\hline & $\lim$ & $3.6-3.9$ & $3.2-4.2$ & $3.4-4.0$ & $3.2-4.3$ \\
\hline & mean & 3.78 & 3.73 & 3.79 & 3.66 \\
\hline & SD & - & 0.27 & 0.25 & 0.33 \\
\hline \multirow{4}{*}{$\mathrm{p} 1, \mathrm{~W}$} & $n$ & 4 & 20 & 5 & 12 \\
\hline & $\lim$ & $2.2-2.8$ & $1.7-3.3$ & $2.4-2.8$ & $2.1-2.8$ \\
\hline & mean & 2.48 & 2.39 & 2.55 & 2.43 \\
\hline & SD & - & 0.30 & 0.16 & 0.19 \\
\hline \multirow{4}{*}{$\mathrm{p} 2, \mathrm{~L}$} & $n$ & 12 & 23 & 6 & 13 \\
\hline & $\lim$ & $7.8-9.3$ & $5.2-9.1$ & $7.3-8.7$ & $7.1-8.9$ \\
\hline & mean & 8.42 & 7.96 & 8.03 & 8.01 \\
\hline & SD & 0.49 & 0.73 & 0.53 & 0.43 \\
\hline \multirow{4}{*}{$\mathrm{p} 2, \mathrm{~W}$} & $n$ & 12 & 23 & 6 & 13 \\
\hline & $\lim$ & $3.0-3.4$ & $2.5-3.3$ & $2.7-3.2$ & $2.7-3.9$ \\
\hline & mean & 3.17 & 3.03 & 2.99 & 3.12 \\
\hline & SD & 0.15 & 0.21 & 0.20 & 0.32 \\
\hline \multirow{4}{*}{ p3, L } & $n$ & 11 & 23 & 6 & 13 \\
\hline & $\lim$ & $8.5-10.3$ & $8.3-9.7$ & $8.0-9.5$ & $7.5-9.4$ \\
\hline & mean & 9.33 & 8.80 & 8.61 & 8.82 \\
\hline & SD & 0.55 & 0.41 & 0.60 & 0.52 \\
\hline \multirow{4}{*}{$\mathrm{p} 3, \mathrm{~W}$} & $n$ & 11 & 23 & 6 & 13 \\
\hline & $\lim$ & $3.0-3.5$ & $2.6-3.5$ & $2.9-3.4$ & $2.7-3.7$ \\
\hline & mean & 3.28 & 3.18 & 3.13 & 3.21 \\
\hline & SD & 0.16 & 0.23 & 0.19 & 0.29 \\
\hline \multirow{4}{*}{$\mathrm{p} 4, \mathrm{~L}$} & $n$ & 16 & 23 & 6 & 13 \\
\hline & $\lim$ & $8.8-10.1$ & $8.4-10.1$ & $8.6-9.9$ & $8.3-10.1$ \\
\hline & mean & 9.37 & 9.26 & 9.02 & 9.21 \\
\hline & SD & 0.38 & 0.40 & 0.49 & 0.46 \\
\hline \multirow{4}{*}{$\mathrm{p} 4, \mathrm{~W}$} & $n$ & 16 & 23 & 6 & 13 \\
\hline & $\lim$ & $3.4-4.2$ & $3.2-4.3$ & $3.7-4.3$ & $3.5-4.3$ \\
\hline & mean & 3.87 & 3.87 & 3.91 & 3.92 \\
\hline & SD & 0.26 & 0.27 & 0.21 & 0.30 \\
\hline \multirow{4}{*}{$\mathrm{ml}, \mathrm{L}$} & $n$ & 11 & 23 & 6 & 13 \\
\hline & $\lim$ & $15.0-16.7$ & $13.4-16.1$ & $13.1-15.9$ & $13.4-16.4$ \\
\hline & mean & 15.79 & 14.86 & 14.45 & 15.15 \\
\hline & SD & 0.55 & 0.73 & 0.98 & 0.71 \\
\hline \multirow{4}{*}{$\mathrm{m} 1$, Ltald } & $n$ & 11 & 23 & 6 & 13 \\
\hline & $\lim$ & $4.3-5.4$ & $3.8-5.2$ & $3.8-5.0$ & $4.0-5.1$ \\
\hline & mean & 5.00 & 4.38 & 4.45 & 4.64 \\
\hline & SD & 0.32 & 0.34 & 0.43 & 0.42 \\
\hline \multirow{4}{*}{$\mathrm{m} 1, \mathrm{~W}$} & $n$ & 11 & 23 & 6 & 13 \\
\hline & $\lim$ & $5.1-6.5$ & $5.2-6.6$ & $5.5-6.3$ & $5.5-6.4$ \\
\hline & mean & 5.99 & 5.93 & 5.89 & 6.01 \\
\hline & SD & 0.43 & 0.35 & 0.31 & 0.28 \\
\hline \multirow{4}{*}{$\mathrm{m} 2, \mathrm{~L}$} & $n$ & 9 & 23 & 6 & 13 \\
\hline & $\lim$ & $6.5-7.6$ & $6.1-7.5$ & $6.6-7.2$ & $5.7-7.9$ \\
\hline & mean & 7.01 & 6.84 & 6.86 & 7.04 \\
\hline & SD & 0.33 & 0.42 & 0.18 & 0.59 \\
\hline \multirow{4}{*}{$\mathrm{m} 2, \mathrm{~W}$} & $n$ & 9 & 23 & 6 & 13 \\
\hline & $\lim$ & $4.8-5.8$ & $4.5-5.6$ & $4.9-5.7$ & $4.4-6.4$ \\
\hline & mean & 5.29 & 5.03 & 5.18 & 5.64 \\
\hline & SD & 0.36 & 0.29 & 0.32 & 0.58 \\
\hline
\end{tabular}



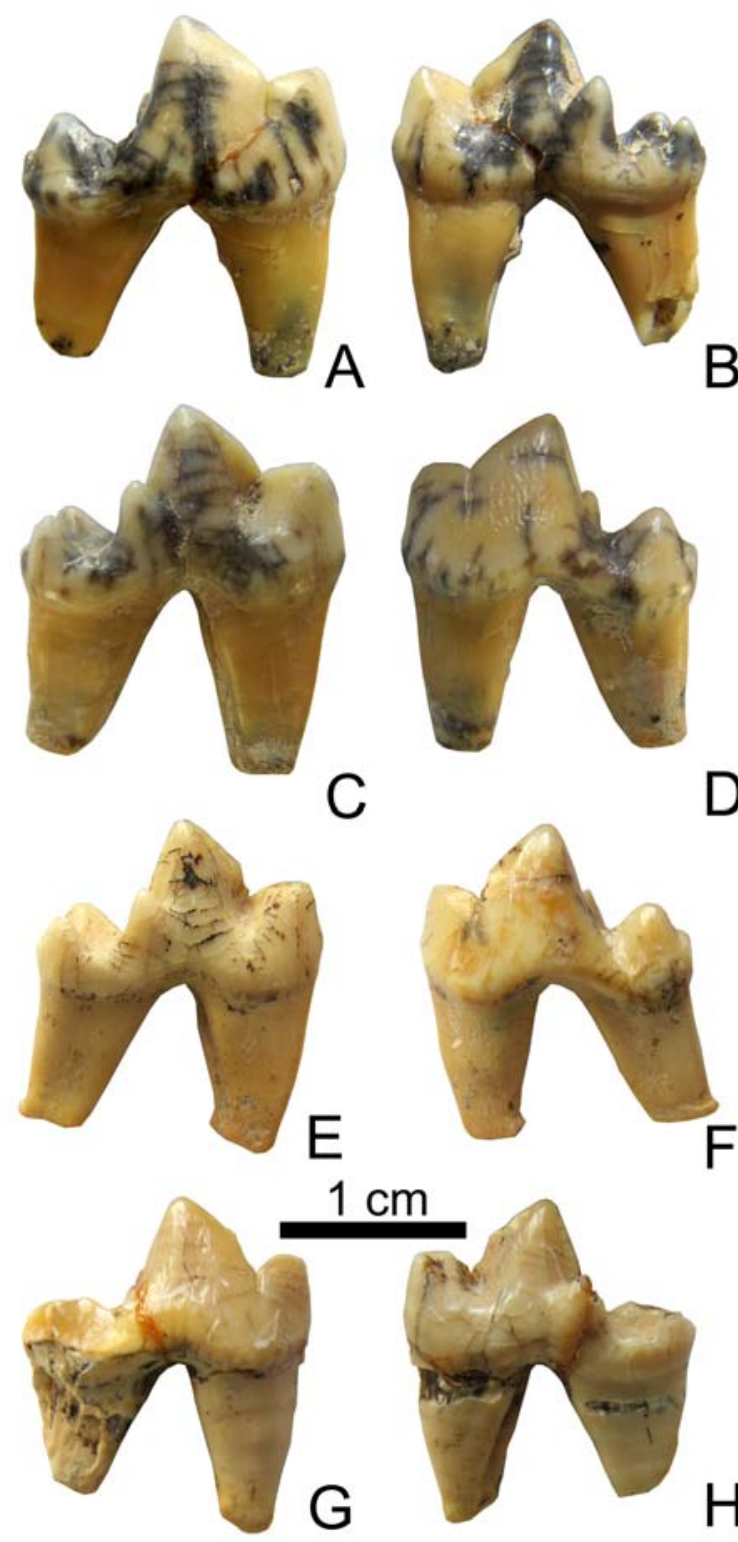

Figure 18. Lower carnassial tooth $\mathrm{P} 4$ of Vulpes vulpes from Kudaro 1 (A-D) and Kudaro 3 (E-H); labial (A, D, F, G) and lingual $(B, C, E, H)$ views.

A, B - ZIN 36506-1; C, D - ZIN 36503; E, F - ZIN 36518-2; G, $\mathrm{H}-\mathrm{ZIN} 36593-11$.

Discussion. Remains of $V$. vulpes occur in all layers of both Kudaro caves. These fossils are the most numerous among examined species of canids.

The bones of red fox may have accumulated in several ways. The animals often dig holes inside caves, near the entrance, and may perish there. Foxes also could have been hunted by ancient hominins; however, no cut-marks or any other signs of butchering were found on the bones. The primary agent of accumulation probably was large carnivores. For examples, in the southern part of Russian Far East, red fox is recorded as the prey of wolf (Canis lupus) and, less commonly, of tiger (Panthera tigris) and leopard (P. pardus) (Yudin, 1992; Pikunov \& Korkishko, 1992; Yudin \& Yudina, 2009). Foxes also are attacked by eagles and large owls (Yudin, 1986).

Vulpes vulpes is found in many sites of the Southern Caucasus (Bronzovaya, Medvezhiya, Verkhnayay, Dzhchula and Sakazhiya in Georgia, Erevanskaya in Armenia, Binagady and Taglar in Azerbaijan), as well of the Northern Caucasus (Barakaevskaya) (Vereshchagin, 1959; Lioubine, 1989). Vereshchagin (1951) recorded two species of fox in the Binagady fauna: Vulpes corsak and $V$. vulpes aff. alpherakyi, indicating considerable morphological similarity between fossil red fox and the recent subspecies $V$. v. alpherakyi, comprising animals from semi-desert plains of Azerbaijan. Presumably, the subspecies of $V$. vulpes evolved in the Southern Caucasus as early as the Late Pleistocene.

The genus Vulpes is known in North America from the Late Miocene ( $V$. kernensis Tedford et al., 2009, $V$. stenognathus Savage, 1941) (Tedford et al., 2009). Small foxes are recorded in the Pliocene and early Pleistocene fauna of Eurasia (Bonifay, 1971; Qiu \& Tedrord, 1990). The origin of $V$. vulpes is associated with the Old Word, and this species is derived from the Late Pliocene $V$. alopecoides Del Campana, 1913; in the Late Pleistocene, this species dispersed to North America (Kurtén \& Anderson, 1980).

The molecular phylogeny of canids reveals the monophyly of the genus Vulpes, species of which exhibit limited variability (Zravý \& Řičánková, 2004). Another molecular study shows that the basal position to Vulpes is occupied by the genus Fennecus and Vulpes vulpes is clustered with $V$. corsak (Bardeleben et al., 2005b).

\section{Conclusions}

The Kudaro caves yield more canid species than other sites in the Caucasus and adjacent regions. Seven canid species have been identified here: Canis arnensis kudarensis ssp. nov., C. mosbachensis, C. lunellensis, C. lupus, Cuon alpinus caucasicus, Vulpes praeglacialis, and $V$. vulpes. Only two species (Canis lupus and Vulpes vulpes) have survived in the Caucasus until the present.

The Kudaro fauna does not contain Vulpes corsak, which is recorded for the Pleistocene of eastern areas of Southern Caucasus (Binagady). As in other Caucasian sites, the arctic fox Vulpes lagopus, a typical representative of mammoth biome, did not occur here.

Baryshnikov (2002) established several faunal units (f. u.) for the Pleistocene of the Caucasus. The earliest finds of canids in Kudaro caves (Kudaro 1 Cave, layer $5 \mathrm{c}$ and Kudaro 3 Cave, layer 8) are assigned to the Kudaro f. u., which is characteristic of the middle Middle Pleistocene: Canis arnensis kudarensis ssp. nov., C. mosbachensis, Vulpes praeglacialis, and $V$. 

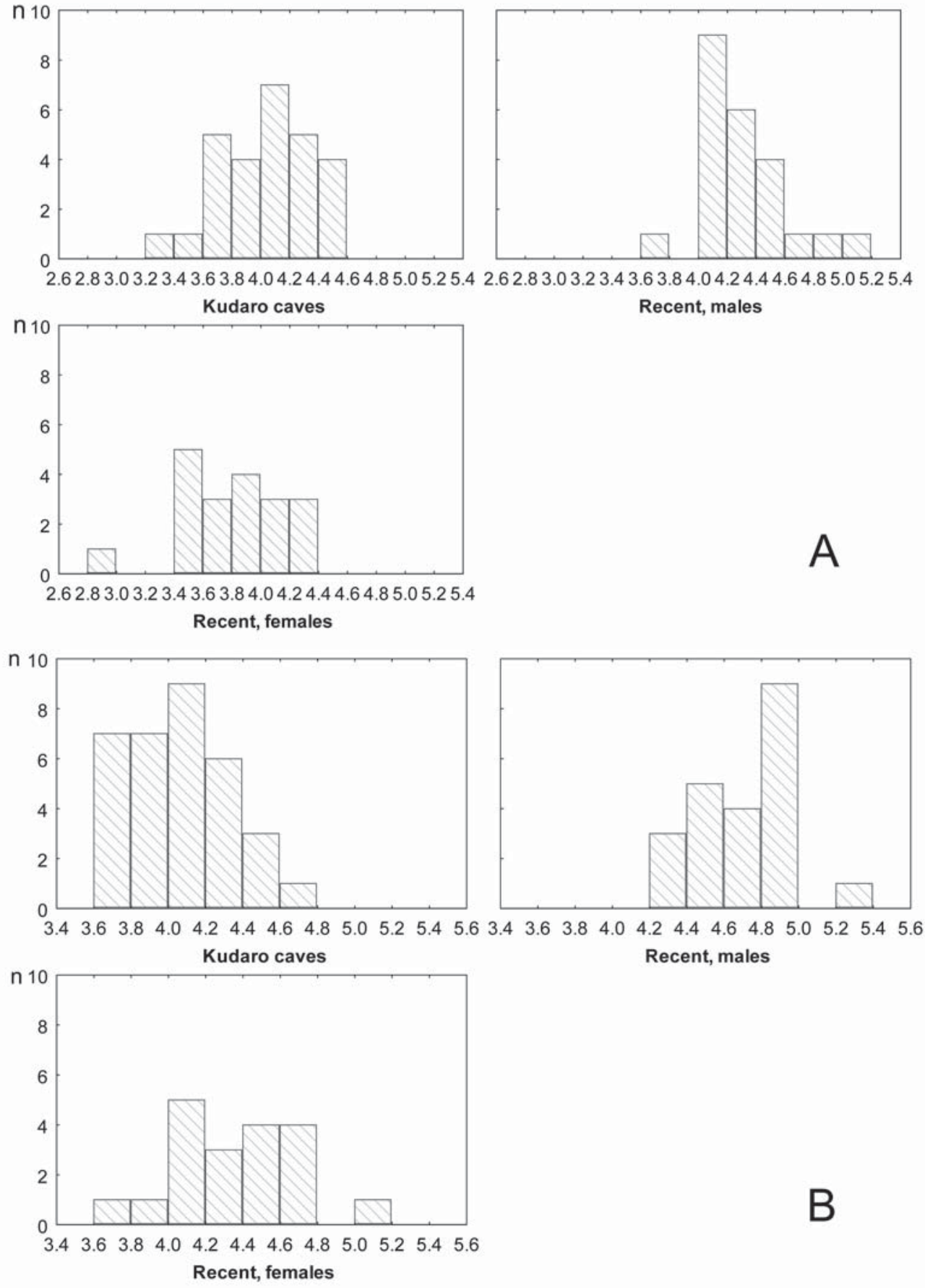

B

Figure 19. Frequency distribution of upper (A) and lower (B) canines width (in mm) of Vulpes vulpes from Caucasus: Pleistocene (Kudaro 1 and Kudaro 3) and Recent.

vulpes. It was replaced by the Kvaisa f. u. (Kudaro 3 Cave, layers 5-7) of the late Middle Pleistocene age, comprising $C$. lunellensis and $V$. vulpes. At the same time, Canis arnensis, C. mosbachensis, and C. lunellensis survived in the Southern Caucasus longer than in Europe, which was a factor of local environmental conditions. The Late Pleistocene Binagady f. u. and
Chasaval f. u. (Kudaro caves, layers 3-4) include three species: Canis lupus, Cuon alpinus caucasicus, and Vulpes vulpes. Therefore, only Vulpes vulpes has been found at all levels within the caves.

The majority of the identified species are characteristic of the Caucasus and Mediterranean European regions. At the same time, Canis lupus and Cuon alpinus 
Table 24. Measurements (in mm) of limb bones of Pleistocene and recent Vulpes vulpes from Caucasus.

\begin{tabular}{|c|c|c|c|c|c|c|c|c|c|c|c|c|c|}
\hline \multirow{2}{*}{ Bones } & \multirow{2}{*}{$\begin{array}{l}\text { Measu- } \\
\text { rements }\end{array}$} & \multicolumn{4}{|c|}{ Kudaro 1 and Kudaro 3} & \multicolumn{4}{|c|}{ Binagady } & \multicolumn{4}{|c|}{ Recent (males and females) } \\
\hline & & $n$ & $\lim$ & $\mathrm{M}$ & SD & $n$ & $\lim$ & $\mathrm{M}$ & $\mathrm{SD}$ & $n$ & $\lim$ & $\mathrm{M}$ & SD \\
\hline \multicolumn{14}{|c|}{ Fore limb } \\
\hline \multirow{3}{*}{ Scapula } & SLC & 2 & $14.7,16.7$ & - & - & 6 & $14.0-15.8$ & 14.92 & 0.60 & & & & \\
\hline & GLP & 2 & $16.4,18.5$ & - & - & 6 & $16.0-17.5$ & 16.67 & 0.62 & & & & \\
\hline & BG & 2 & $9.0,11.4$ & - & - & 6 & $8.9-11.0$ & 10.11 & 0.73 & & & & \\
\hline \multirow{4}{*}{$\begin{array}{l}\text { Hume- } \\
\text { rus }\end{array}$} & $\mathrm{Bp}$ & 2 & $19.5,20.0$ & - & - & 2 & $19.3,19.4$ & - & - & 4 & $15.9-17.4$ & 16.32 & 0.72 \\
\hline & $\mathrm{Dp}$ & 2 & $24.2,24.5$ & - & - & 2 & $23.7,23.8$ & - & - & 4 & $23.1-24.9$ & 23.8 & 0.77 \\
\hline & $\mathrm{Bd}$ & 4 & $18.5-21.2$ & 19.92 & 1.33 & 2 & $18.6,19.1$ & - & - & 4 & $18.7-20.4$ & 19.41 & 0.72 \\
\hline & $\mathrm{Dd}$ & 4 & $13.5-15.1$ & 14.17 & 0.70 & 2 & $13.5,14.9$ & - & - & 4 & $13.7-15.8$ & 14.31 & 0.99 \\
\hline \multirow{6}{*}{ Radius } & GL & 1 & 115.5 & - & - & 1 & 112.2 & - & - & 4 & $\begin{array}{c}108.0- \\
114.4\end{array}$ & 111.0 & 2.72 \\
\hline & $\mathrm{Bp}$ & 11 & $10.2-12.0$ & 11.12 & 0.60 & 2 & $10.5,10.9$ & - & - & 4 & $10.6-11.3$ & 11.05 & 0.31 \\
\hline & $\mathrm{Dp}$ & 13 & $6.3-7.5$ & 7.08 & 0.34 & 2 & $7.0,7.0$ & - & - & 3 & $6.7-6.9$ & 6.80 & - \\
\hline & SD & 4 & $7.2-10.2$ & 8.45 & 1.27 & 3 & $8.0-8.7$ & 8.37 & - & & & & \\
\hline & $\mathrm{Bd}$ & 2 & $11.6,14.8$ & - & - & 1 & 14.4 & - & - & 3 & $13.6-14.2$ & 14.02 & - \\
\hline & $\mathrm{Dd}$ & 2 & $7.9,7.9$ & - & - & 1 & 8.3 & - & - & 3 & $7.4-8.3$ & 7.90 & - \\
\hline \multirow{3}{*}{ Ulna } & DPA & 7 & $14.0-15.7$ & 15.07 & 0.61 & 16 & $14.1-16.0$ & 15.06 & 0.58 & 3 & $14.2-14.7$ & 14.43 & - \\
\hline & SDO & 5 & $12.4-13.5$ & 13.10 & 0.45 & 16 & $12.2-13.6$ & 12.89 & 0.46 & 3 & $11.7-12.9$ & 12.40 & - \\
\hline & $\mathrm{BPC}$ & 8 & $7.8-10.2$ & 8.89 & 0.77 & 16 & $8.1-10.3$ & 8.97 & 0.63 & 3 & $8.1-10.3$ & 8.93 & - \\
\hline \multirow{2}{*}{$\mathrm{Mc} 2$} & GL & 3 & $37.7-48.1$ & 37.7 & - & 1 & 48.5 & - & - & & & & \\
\hline & SD & 3 & $4.3-4.9$ & 4.70 & - & 1 & 4.0 & - & - & & & & \\
\hline \multirow{2}{*}{ Mc3 } & GL & 4 & $44.2-48.1$ & 46.20 & 1.59 & & & & & 3 & $42.4-44.6$ & 43.37 & - \\
\hline & SD & 3 & $3.5-4.8$ & 3.93 & - & & & & & 3 & $3.4-3.6$ & 3.50 & - \\
\hline \multirow{2}{*}{ Mc5 } & GL & 4 & $36.5-45.6$ & 41.42 & 4.01 & & & & & 4 & $35.3-38.9$ & 36.52 & 1.67 \\
\hline & SD & 4 & $3.9-5.3$ & 4.65 & 0.60 & & & & & 4 & $4.0-4.3$ & 4.15 & 0.13 \\
\hline \multicolumn{14}{|c|}{ Hind limb } \\
\hline \multirow{2}{*}{ Pelvis } & LA & 3 & $11.5-15.6$ & 13.33 & - & 10 & $11.9-14.4$ & 13.33 & 0.81 & 4 & $11.6-13.4$ & 12.32 & 0.76 \\
\hline & $\mathrm{SH}$ & 2 & $12.1,13.1$ & - & - & 9 & $9.6-12.1$ & 10.98 & 0.71 & & & & \\
\hline Femur & $\mathrm{Bd}$ & 1 & 25.5 & - & - & 1 & 19.0 & - & - & & & & \\
\hline \multirow{4}{*}{ Tibia } & $\mathrm{Bp}$ & 1 & 20.4 & - & - & & & & & & & & \\
\hline & SD & 1 & 8.3 & - & - & & & & & & & & \\
\hline & $\mathrm{Bd}$ & 6 & $14.5-18.0$ & 15.52 & 1.34 & 14 & $13.7-15.2$ & 14.37 & 0.50 & 4 & $13.4-15.2$ & 14.28 & 0.83 \\
\hline & $\mathrm{Dd}$ & 7 & $10.1-12.2$ & 10.71 & 0.79 & 14 & $9.2-11.8$ & 10.53 & 0.81 & 4 & $9.6-11.0$ & 10.30 & 0.62 \\
\hline \multirow{2}{*}{ Talus } & GL & 2 & $18.9,20.0$ & - & - & & & & & 4 & $17.1-18.7$ & 17.65 & 0.72 \\
\hline & GB & 2 & $11.4,13.1$ & - & - & & & & & 4 & $10.9-12.8$ & 11.85 & 0.88 \\
\hline \multirow{2}{*}{$\begin{array}{l}\text { Calca- } \\
\text { neus }\end{array}$} & GL & 11 & $30.6-33.5$ & 32.25 & 1.18 & & & & & 4 & $27.7-30.3$ & 28.97 & 1.12 \\
\hline & GB & 14 & $10.7-13.6$ & 12.22 & 0.92 & & & & & 4 & $10.6-12.6$ & 11.60 & 0.82 \\
\hline
\end{tabular}

may be regarded as the northern invaders of the Caucasus region.

During formation of the Kudaro cave sediments, representatives of the genus Canis exhibit changes in the size and morphology of their cheek teeth, which provide a basis for recognizing the replacement of several taxa over time; in contrast, the genus Vulpes ( $V$. vulpes) exhibits conservatism in its dental characteristics.

ACKNOWLEDGEMENTS. I am grateful to Prof. V.P. Lioubine (St. Petersburg) for the invitation to participate in the study of the Kudaro cave sites. Comparative fossil collections were provided by Dr. G.G. Boeskorov (Yakutsk), Prof. A. Lister and Dr. A. Currant (London), Dr. V. Eisenmann and Dr. St. Péan (Paris), Prof. C. Guérin (Lyon), Dr. H. Lutz and Mr. T. Engel (Mainz), Prof. C. Petronio (Roma), Dr. E. Tsoukala (Thessaloniki), Prof. A. Nadachowski (Krakow), Dr. J. Wagner (Prague), Dr. M. Galetová (Brno), Prof. A. David and Dr. T. Obade (Kishinev), Prof. M. Zeder
(Washington). Elena Syromiatnikova (St. Petersburg) assisted me in working with the collection. My wife, Svetlana Baryshnikova, helped improve the manuscript. I am very grateful to Dr. J. Hoffecker (Boulder, CO, USA) for correction of the English text of my paper.

The study was supported financially by the Russian Foundation for Basic Research (grant \# 09-04-01770a). This work was supported by the Ministry of Education and Science of the Russian Federation.

\section{References}

Argant A. 1991. Carnivores Quaternaires de Bourgogne // Documents des Laboratoires de Géologie Lyon. Vol.115. P.1-301.

Argant A. 2004. Les carnivores du gisement Pliocène final de Saint-Vallier (Drôme, France) // Geobios. Vol.37. P.133-182.

Argant A. 2009. Biochronologie et grands mammifères au Pléistocène moyen et supérieur en Europe occidentale: 
l'apport des canidés, des ursidés et des carnivores en general // Quaternaire Vol.20. No.4. P.467-480.

Aristov A.A. \& Baryshnikov G.F. 2001. [The Mammals of Russia and Adjacent Territories. Carnivores and Pinnipeds]. St. Petersburg. 560 p. [in Russian]

Azzaroli A. 1983. Quaternary mammals and the "end-Villafranchian" dispersal event - A turning point in the history of Eurasia. Palaeogeography, Palaeoclimatology, Palaeoecology. Vol.44. P.117-139.

Bardeleben C., Moore R.L. \& Wayne R.K. 2005a. Isolation and Molecular Evolution of the Selenocysteine tRNA (Cf TRSP) and RNase P RNA (Cf RPPH1) Genes in the Dog Family, Canidae // Molecular Biology and Evolution. Vol.22. No.2. P.347-359.

Bardeleben C., Moore R.L. \& Wayne R.K. 2005b. A molecular phylogeny of the Canidae based on six nuclear loci // Molecular Phylogenetics and Evolution. Vol.37. P.815831.

Baryshnikov G. 1978. [Dhole from Caucasus] // Trudy Zoologicheskogo Instituta AN SSSR. T.79. P.79-84 [in Russian]

Baryshnikov G. 1986. [Pleistocene wolfs (genus Canis) of the Greatest Caucasus] // Trudy Zoologicheskogo Instituta AN SSSR. T.149. P.33-52 [in Russian].

Baryshnikov G. 1994. [Large mammals of the Acheulean site in the Treugolnaya Cave of the North Caucasus] // Trudy Zoologicheskogo Instituta AN SSSR. 1993. T.249. P.347 [in Russian].

Baryshnikov G. 1995. [Pleistocene dhole, Cuon alpinus (Carnivora, Canidae), from Paleolithic sites of the Greatest Caucasus] // Trudy Zoologicheskogo Instituta AN SSSR. T.263. P.92-120 [in Russian].

Baryshnikov G. 1996. The dhole, Cuon alpinus (Carnivora, Canidae), from the Upper Pleistocene of the Caucasus // Acta Zoologica Cracovensis. Vol.39. No.1. P.67-73.

Baryshnikov G. 1998. Cave bears from the Paleolithic of the Greater Caucasus // Saunders J.J., Styles B.W. \& Baryshnikov G.F. (eds.). Quaternary Paleozoology in the Northern Hemisphere. Springfield. P.69-118. (Illinois State Mus. Sci. Papers, Vol.27.)

Baryshnikov G. 2010a. Middle Pleistocene Ursus thibetanus (Mammalia, Carnivora) from Kudaro caves in the Caucasus // Proceeding of the Zoological Institute RAS. Vol.314. P.67-79.

Baryshnikov G. 2010b. Pleistocene Mustelidae (Carnivora) from Paleolithic site in Kudaro Caves in the Caucasus // Russian Journal of Theriology. Vol.8 (for 2009). P.75-95.

Baryshnikov G. 2011a. Late Pleistocene brown bear (Ursus arctos) from the Caucasus // Russian Journal of Theriology. Vol.9 (for 2010). P.9-17.

Baryshnikov G. 2011b. Pleistocene Felidae (Mammalia, Carnivora) from Paleolithic site in Kudaro Caves in the Caucasus // Proceeding of the Zoological Institute RAS. Vol.315. No.3. P.197-226.

Baryshnikov G., Mool D. \& Tikhonov A. 2010. Finding of the Late Pleistocene Carnivora in Taimyr Peninsula (Russia, Siberia) with paleoecological context // Russian Journal of Theriology. Vol.8 (for 2009). No.2. P.107-113.

Baryshnikov G. \& Tsoukala E. 2011. New analysis of the Pleistocene carnivores from Petralona Cave (Macedonia,
Greece) based on the Collection of the Thessaloniki Aristotle University // Geobios. Vol.43. P.389-402.

Bigaj J. 1963. Szczątki Canidae z Pleistocenu polski // Folia Quaternaria. Krakow. No.13. P.1-18.

Bishop J. 1982. The mammal fauna of the early middle Pleistocene cavern infull site of Westburry-sub-Mendip // Somerset. Special Papers in Palaeontology. London. Vol.28. P.1-108.

Bonifay M.-F. 1971. Carnivores quaternaries du sud-est de la France // Mémoires du Muséum National d'Histoire Naturelle, Ser. C. T.21. Fasc.2. P.43-377 + XXVII Pls.

Bonifay M.-F. 1983. Les canidés de Vergranne // Annales Scientifiques de l'Université de France-Comté. Géologie. Fasc.5. 4éme série. P.111-123.

Brugal J.-Ph. \& Boudadi-Maligne M. 2011. Quaternary small to large canids in Europe: Taxonomic status and biochronological contribution // Quaternary International. Vol.243. No.1. P.171-182.

Calero J.A.C., Montoya P., Mancheno M.A. \& Morales J. 2006. Presencia de Vulpes praeglacialis (Kormos, 1932) en el yacimiento pleistoceno de la Sierra de Quibas (Abanilla, Murcia) // Estudios Geológicos. Vol.62. No.1. P.395-400.

Colbert E.H. \& Hooijer D.A. 1953. Pleistocene mammals from the limestone fissures of Szechwan, China // Bulletin of the American Museum of Natural History. Vol.102. Art. P.1-134 + Pls. 40.

Cordy J.-M. 1983. Découverte de Cuon alpinus europeaeus Bourguignat dans le Quaternaire de Belgique // Mémoire de la Société Préhistorique Française. Vol.16. S.49-54.

Del Campana D. 1913. I cani pliocenici di Toscana // Palaeontographica Italica. T.19. P.189-254.

Delson E., Faure M., Guérin C., Aprile L., Argant J., Blackwell B.A.B., Debard E., Harcourt-Smith W., MartinSuarez E., Monguillon A., Parenti F., Pastre J.-F., Sen S., Skinner A.R., Swisher C.C. \& Valli A.M.F. 2006. Franco-American renewed research at the Late Villafranchian locality of Senèze (Haute-Loire, France) // Courier Forschungsinstitut Senckenberg. T.256. P.275-290.

Driesch A., von den. 1976. A guide to the measurement of animal bones from archaeological sites // Peabody Museum Bulletin. Vol.1. P.1-136.

Gadzhiev D.V. \& Aliev S.D. 1966. [Some carnivorous mammals (Mammalia, Carnivora) from Palaeolithic sediments in Azykh Cave] // Uzenye Zapiski Azerbaijanskogo Gosudarstvennogo Meditsinskogo Instituta. T.23. P.7-13 [in Russian]

Garrido G. \& Arribas A. 2008. Canis accitanus nov. sp., a new small dog (Canidae, Carnivora, Mammalia) from the Fonelas P-1 Plio-Pleistocene site (Guadix basin, Granada, Spain) // Geobios. Vol.41. P.751-761.

García N. 2003. Osos y Otros Carnívoros de la Sierra de Atapuerca. Oviedo: Fundacio'n Oso de Asturias. 575 p. Iyengar A., Babu V.N., Hedges S., Venkataraman A.B., Maclean N. \& Morin P.A. 2005. Phylogeography, genetic structure, and diversity in the dhole (Cuon alpinus) // Molecular Ecology. Vol.14. P.2281-2297.

Kormos T. 1932. Die Füchse des ungarischen Oberpliozäns // Folia Zoologica et Hydrobiologica. Vol.9. No.2. S.167$188+1$ Taf 
Kufos G.D. 1987. Canis arnensis Del Campana, 1913 from the Villafranchian (Villanyian) of Macedonia (Greece) // Paleontologia I Evolucio. T.21. P.3-10.

Kuz'mina I.E. \& Sablin M.V. 1994. [Wolf (Canis lupus) from Upper Paleolithic sites of Kostenki in Don River] // Trudy Zoologicheskogo Instituta RAN. Vol.256. P.44 58 [in Russian].

Kurtén B. 1968. Pleistocene Mammals of Europe. London: Weidenfeld and Nicolson. $317 \mathrm{p}$.

Kurtén B. 1969. Die Carnivoren-Reste aus den Kiesen von Süssenborn bei Weimar // Paläontologische Abhandlungen. Abteil. A. Bd.3. Hf.3/4. S.735-756.

Kurtén B. 1974. A history of coyote-like dogs (Canidae, Mammalia) // Acta Zoologica Fennica. No.140. P.1-38.

Kurtén B. \& Anderson E. 1980. Pleistocene Mammals of North America. New York: Columbia University Press. $443 \mathrm{p}$.

Kurtén B. \& Poulianos N. 1977. New stratigraphic and faunal material from Petralona Cave, with special reference to the Carnivora // Anthropos. Vol.4. No.1-2. P.47130.

Kurtén B. \& Poulianos N. 1981. Fossil Carnivora of Petralona Cave. Status of 1980 // Anthropos. Vol.8. P.9-56.

Leonard J.A., Vila C., Fox-Dobbs K., Koch P.L., Wayne R.K. \& Van Valkenburgh B. 2007. Megafaunal extinctions and the disappearance of a specialized wolf ecomorph // Current Biology. Vol.17. P.1146-1150.

Lioubine V.P. 1989. [Palaeolithic of Caucasus] // Boriskovsky P.I. (ed.). Paleolit Mira. Paleolit Kavkaza i Severnoi Azii. Leningrad: Nauka. P.7-142 [in Russian].

Lioubine V.P. 1998. [The Acheulian epoch of in the Caucasus]. St. Petersburg: Peterburgskoe Vostokovedenie. 192 p. [in Russian].

Madurell-Malapeira J., Alba D.M. \& Moyá-Solá S. 2009. Carnivora from the late Early Pleistocene of Cal Guardiola (Terrassa, Vallés-Penedés basin, Catalonia, Spain) // Journal of Paleontology. Vol.83. No.6. P.969-974.

Martin R. 1973. Trois nouvelles espèces de Caninae (Canidae, Carnivora) des gisements Plio-Villafranchiens d'Europe // Documents des Laboratoires de Géologie Géologie de Lyon. Vol.57. P.87-96.

Martin R. 1975. Les canidés (Mammalia, Carnivora) du gisement Pléistocène moyen des abiemes de la Fage a Noailles (Corrèze) // Nouvelles Archives du Muséum d'Histoire Naturelle de Lyon. Fasc.13. P.17-20.

Martínez-Navarro B. \& Rook L. 2003. Gradual evolution in the African hunting dog lineage: Systematic implications // Compte Rendus Palevol. Vol.2. P.695-702.

Martínez-Navarro B., Toro I. \& Agustí J. 2003. The mammals assemblages from Venta Micena, Fuente Nueva-3 and Barranco León-5 (Orce). Early Pleistocene Faunal and Human dispersals into Europe // Données récentes sur les modalités de peuplement en Europe au Paléolithique inférieur et moyen Rennes, Université de Rennes 1, 22-25 septembre 2003.

Musil R. 1972. Die Caniden der Stránská skála 1. 1910 1945 // Anthropos. No.20 (N.S. 12). S.77-106 + 6 Taf.

Nehring A. 1890. Ueber Cuon alpinus fossilis Nehring, nebst Bemerkungen uber einige andere fossile Caniden // Neues Jahrbuch für Mineralogie, Geologie und Paläontologie.
No.2. S.34-52.

Nowak R.M. 1979. North American Quaternary Canis // Monograph of the Museum of Natural History, University of Kansas. No.6. P.1-154.

Palombo M.R. \& Valli A.M.F. 2004. Remarks on the biochronology of mammalian fauna complexes from the Pliocene to the Middle Pleistocene in France // Geologica Romana. 2003-2004. Vol.37. P.145-163.

Pérez Ripoll M., Morales Pérez J.V., Sanchis Serra A., Aura Tortosa J. E. \& Sarrión Montañana I. 2010. Presence of the genus Cuon in upper Pleistocene and initial Holocene sites of the Iberian Peninsula: new remains identified in archaeological contexts of the Mediterranean region // Journal of Archaeological Science. Vol.37. P.437-450.

Petronio C., Bellucci L., Martiinetto E., Pandolfi L. \& Salari L. 2011. Biochronology and palaeoenvironmental changes from the Middle Pliocene to the Late Pleistocene in Central Italy // Geodiversitas. Vol.33. No.3. P.485-517.

Pikunov D.G. \& Korkishko V.G. 1992. [Leopard of Russian Far East]. Moscow: Nauka. 189 p. [in Russian]

Pilot M., Branicki W., Jędrzejewski W., Goszczyński J., Jêdrzejewska B., Dykyy I., Shkvyrya M. \& Tsingarska E. 2010. Phylogeographic history of grey wolves in Europe // Evolutionary Biology. Vol.10. P.104.

Qiu Z.-X. \& Tedford R.H. 1990. [A Pliocene species of Vulpes from Yushe, Shanxi] // Vertebrate Palasiatica. Vol.10. P.245-258 [in Chinese with English summary].

Sardella R. \& Palombo M.R. 2007. The Pliocene-Pleistocene boundary: which significance for the so-called "Wolf event"? Evidences from Western Europe // Quaternaire. Vol.18. P.65-71.

Schaefer H. 1969. Zwei Caniden-Reste (Carnivora, Mammalia) aus dem Altpleistozän von Süßenborn bei Weimar // Paläontologische Abhandlungen. Berlin. Abt.A. Bd.3. S.757-760.

Sen S., de Bonis L., Dalfes N., Geraads D., Jaeger J.-J. \& Mazin J.-M. 1991. Première découverte d'un site à mammifères pléistocènes dans une fissure karstique en Anatolie centrale // Comptes Rendus de 1 Academie des Sciences, Paris. Sér.II. T.313. P.127-132.

Soergel W. 1928. Ein kleiner Wolf aus den Kiesen von Süßenborn // Zeitschrift der Deutschen Geologischen Gesellschaft. Berlin. Bd.80. S.227-237.

Sommer R. \& Benecke N. 2005. Late-Pleistocene and early Holocene history of the canid fauna of Europe (Canidae) // Mammalian Biology. Vol.70. No.4. P.227-241.

Spassov N. 2003. The Plio-Pleistocene vertebrate fauna in South-Eastern Europe and the megafaunal migratory waves from the east to Europe // Revue Paléobiologie. Genève. T.22. No 1. P.197-229.

Szuma E. 2004. Evolutionary implications of morphological variation in the lower carnassial of red fox Vulpes vulpes // Acta Theriologica. Vol.49. No.4. P.433-447.

Szuma E. 2007. Geography of dental polymorphism in the red fox Vulpes vulpes and its evolutionary implications // Biological Journal of the Linnean Society. Vol.90. P.6184.

Szuma E. 2008. Evolutionary and climatic factors affecting tooth size in the red fox Vulpes vulpes in the Holarctic // Acta Theriologica. Vol.53. No.4. P.289-332. 
Tedford R.H., Wang X. \& Taylor B.E. 2009. Phylogenetic systematics of the North American fossil Caninae (Carnivora: Canidae) // Bulletin of the American Museum of Natural History. Vol.325. P.1-218.

Thenius E. 1954. Die Caniden (Mammalia) aus dem Altquartär von Hundsheim (Niederösterreich) nebst Bemerkungen zur Stammesgeschichte der Gattung Cuon // Neues Jahrbuch für Geologie und Paläontology, Abhandlungen. Bd.99. No.2. S.230-286.

Thenius E. 1956. Die Carnivoren-Reste aus dem Altpleistozän von Voigtstedt bei Sangerhausen in Thüringen // Paläontologische Abhandlungen. Abteilung A. Bd.2. Heft 2/3. S.538-564.

Torre D. 1967. I cani villafranchiani della Toscana // Palaeontographica Italica. T.63. P.113-138.

Vekua A.K. 1962. [Lower Pleistocene mammal fauna from Akhalkalaki]. Tbilisi: Izdatelstvo Academii Nauk GSSR. 207 p. [in Georgian]

Vekua A.K. Gabelaya T.D., Muskhelishvili A.T. \& Mamatsashvili N.S. 1987. [To study of Paleolithic vertebrate fauna from Tsona Cave] // Peshchery Gruzii. No.11. P.92-100 [in Russian].

Vereshchagin N.K. 1951. [Carnivora from Binagady asphalt site] // Trudy Estestvenno-Istoricheskogo Muzeya AN AzerbSSR. Vol.4. P.28-126 [in Russian].

Vereshchagin N.K. 1957. [Pleistocene vertebrates from Kudaro 1 Cave in South Ossetia and their role in the reconstruction of the history of fauna and landscapes of Caucasus] // Doklady AN SSSR. T.112. No.6. P.1347-1349 [in Russian].

Vereshchagin N.K. 1959. [Mammals of Caucasus. History of Fauna Origin]. Moskva-Leningrad: Izdatelstvo Akademii Nauk SSSR. 704 p. [in Russian].

Vereshchagin N.K. \& Baryshnikov G.F. 1980. [Mammal remains from Eastern galleria of Kudaro 1 Cave (excavation V.P. Lioubine 1957-1958)] // Ivanova I.K. \& Cherniakhovsky (eds.). Kudarskie Peshchernye Paleoliticheskie Stoyanki v Yugo-Osetii (Voprosy Stratigrafii, Ekologii, Khronologii). Moskva: Nauka. P.51-62 [in Russian].

Wang X., Tedford R.H., Van Valkenburgh B. \& Wayne R.K. 2004. Evolutionary history, molecular systematics, and evolutionary ecology of Canidae // Macdonald D.W. \& Sillero-Zubiri C. (eds.). Biology and Conservation of Wild Canids. Oxford: Oxford University Press. P.38-54.

Werdelin L. \& Levis M.E. 2000. Carnivora from the South Turkwel hominid site, northern Kenya // Journal of Paleontology. Vol.74. P.1173-7180.

Yudin V.G. 1986. [The Red Fox of Far East of USSR]. Vladivostok: DVNT AN SSSR. 284 p. [in Russian]

Yudin V.G. 1992. [The Wolf of the Far East of Russia]. Blagoveshchensk: DVO RAN. 312 p. [in Russian]

Yudin V.G. \& Yudina E.V. 2009. [The Tiger of the Far East of Russia]. Vladivostok: Dalnauka. 485 p. [in Russian]

Zravý J. \& Řičánková V. 2004. Phylogeny of recent Canidae (Mammalia, Carnivora): relative reliability and utility of morphological and molecular datasets // Zoologica Scripta. Vol.33. P.311-333. 